\title{
Guidelines and Procedures for Computing Time-Series Suspended-Sediment Concentrations and Loads from In-Stream Turbidity-Sensor and Streamflow Data
}

Chapter 4 of

Book 3, Applications of Hydraulics

Section C, Sediment and Erosion Techniques

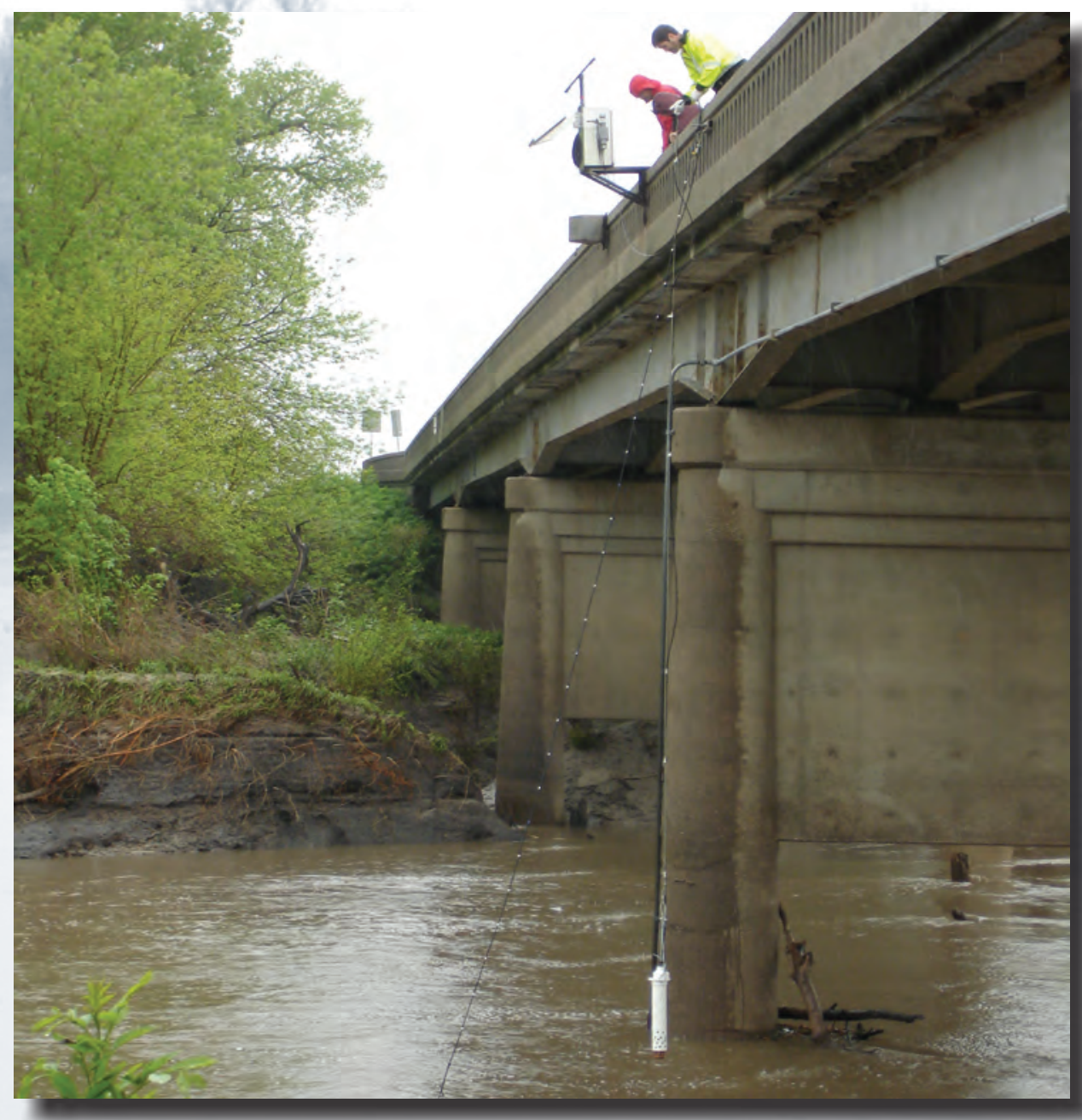

Techniques and Methods 3-C4 
Front cover. Background photograph shows Little Arkansas River near Sedgwick, Kansas. Inset photograph shows waterquality monitors suspended from bridge and lowered by USGS personnel into the Little Arkansas River near Sedgwick, Kansas (all photographs taken by Patrick Rasmussen, USGS) (http://nrtwq.usgs.gov/).

Back cover. Inset is screen capture from USGS Real Time Computed Water Quality for Kansas, Little Arkansas River near Sedgwick site (http://nrtwq.usgs.gov/). 


\section{Guidelines and Procedures for Computing Time-Series Suspended-Sediment Concentrations and Loads from In-Stream Turbidity-Sensor and Streamflow Data}

By Patrick P. Rasmussen, John R. Gray, G. Douglas Glysson, and Andrew C. Ziegler

Chapter 4 of

Book 3, Applications of Hydraulics

Section C, Sediment and Erosion Techniques

Techniques and Methods 3-C4 


\title{
U.S. Department of the Interior \\ KEN SALAZAR, Secretary \\ U.S. Geological Survey \\ Marcia K. McNutt, Director
}

\author{
U.S. Geological Survey, Reston, Virginia: 2009 \\ Revised: 2011
}

For more information on the USGS - the Federal source for science about the Earth, its natural and living resources, natural hazards, and the environment, visit http://www.usgs.gov or call 1-888-ASK-USGS

For an overview of USGS information products, including maps, imagery, and publications, visit http://www.usgs.gov/pubprod

To order this and other USGS information products, visit http://store.usgs.gov

Any use of trade, product, or firm names is for descriptive purposes only and does not imply endorsement by the U.S. Government.

Although this report is in the public domain, permission must be secured from the individual copyright owners to reproduce any copyrighted materials contained within this report.

Suggested citation:

Rasmussen, P.P., Gray, J.R., Glysson, G.D., and Ziegler, A.C., 2009, Guidelines and procedures for computing timeseries suspended-sediment concentrations and loads from in-stream turbidity-sensor and streamflow data: U.S. Geological Survey Techniques and Methods, book 3, chap. C4, 52 p. 


\section{Contents}

Abstract

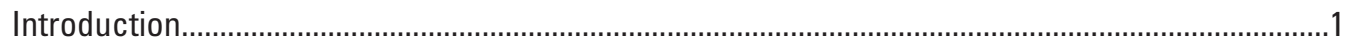

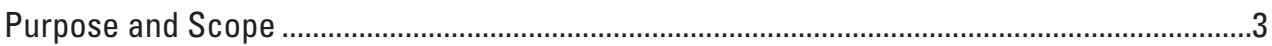

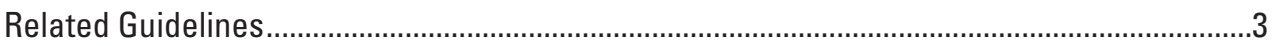

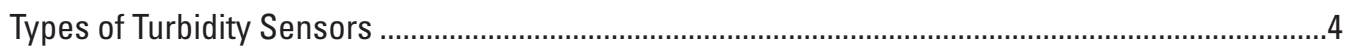

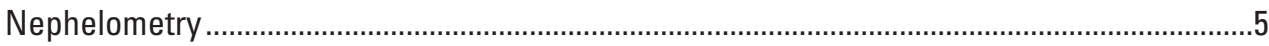

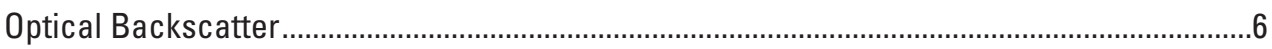

Relation of Turbidity to Suspended-Sediment Concentration ....................................................

Model-Calibration Data Set ..............................................................................................

Evaluation of Fixed-Location and Cross-Section Turbidity .............................................

Determination of Turbidity and Streamflow Associated with Suspended-Sediment

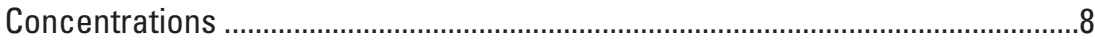

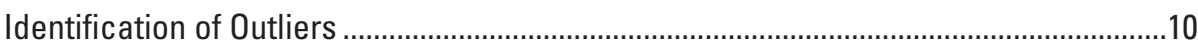

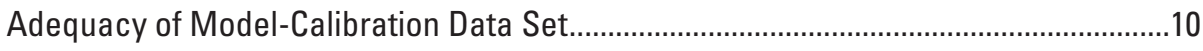

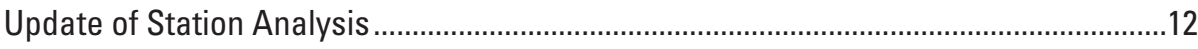

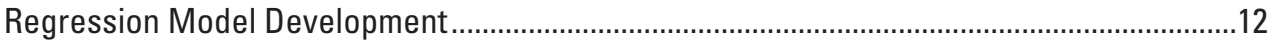

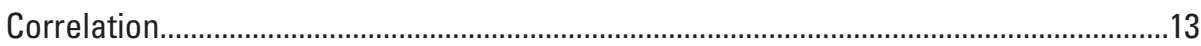

Simple Linear Regression for Computation of Suspended-Sediment Concentrations ..13

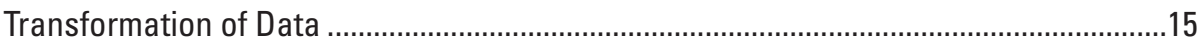

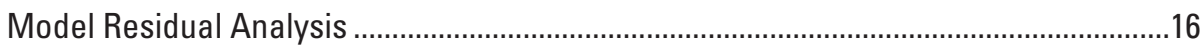

Simple Linear Regression Model and Bias Correction Factor .........................................17

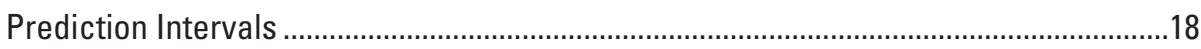

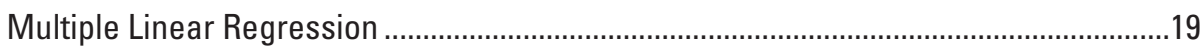

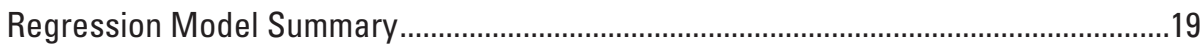

Computation of Suspended-Sediment Concentration and Load Time-Series Record .....................20

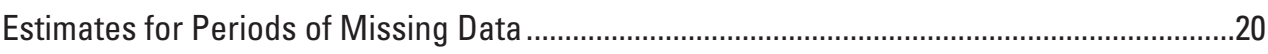

Computation of Suspended-Sediment Load Time-Series Records ........................................22

Model Validation and Maintainenance of a Long-Term Suspended-Sediment

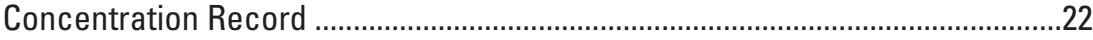

Validation of Suspended-Sediment Concentration Model ...............................................23

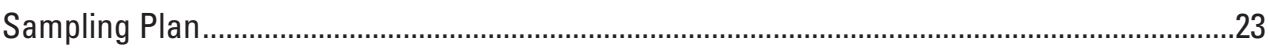

Changes to Turbidity Sensor Model or Type ………................................................................24

Factors Affecting Relation Between Turbidity and Suspended-Sediment

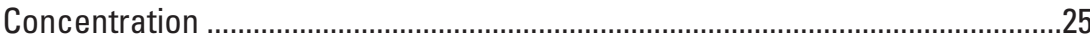

Summary

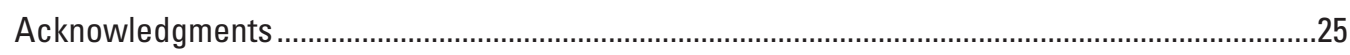

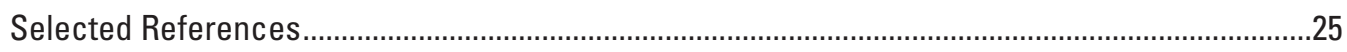

Appendix 1. Examples of Suspended-Sediment Concentration Models from Kansas,

Oregon, Florida, and California .........................................................................................32

Example 1. Complete Review Package for Little Arkansas River near Sedgwick, Kansas....33

Example 2. Turbidity Computed Suspended-Sediment Concentrations from Oregon.............39

Example 3. Turbidity Computed Suspended-Sediment Concentrations from Florida...............44

Example 4. Turbidity Computed Suspended-Sediment Concentrations Using

Nonparametric Regression, California 
Appendix 2. Computation, Storage, and Real-Time Display of Time-Series SuspendedSediment Concentrations and Loads in National Water Information System .. .48

Appendix 3. Comparison of Computed Suspended-Sediment Concentrations with WaterQuality Criteria . 51

\section{Figures}

1. Photographs showing three self-cleaning nephelometric turbidity sensors- $A$, YSI Incorporated (Yellow Springs, Ohio) model 6136 turbidity sensor, B, Hydrolab (Loveland, Colorado) self-cleaning turbidity sensor, and $C$, Forrest Technology Systems (Blaine, Washington) model DTS-12 turbidity sensor .5

2. Photographs showing optical backscatter sensors (A) OBS 3+ (Campbell Scientific, Inc., Logan, Utah) and (B) Hach (Loveland, Colorado) Solitax...

3. Check list for development, verification, and approval of a regression model to compute suspended-sediment concentration and load time-series data.

4-18. Graphs showing -

4. Comparison of fixed-location and median cross-section turbidity measurements for U.S. Geological Survey streamgage on Little Arkansas River near Sedgwick, Kansas, November 1998-June 2005

5. A, Time-series turbidity and streamflow data, August $14-18,2002$, and $B$, duration of cross-section turbidity and suspended-sediment sample collection, August 15, 2002, at U.S. Geological Survey streamgage on Little Arkansas River near Sedgwick, Kansas

6. Comparison of turbidity to suspended-sediment concentration in water from U.S. Geological Survey streamgage on Little Arkansas near Sedgwick, Kansas, August 2000-June 2005

7. Duration curves for $A$, turbidity and $B$, streamflow and corresponding values associated with suspended-sediment concentration samples collected at U.S. Geological Survey streamgage on Little Arkansas River near Sedgwick, Kansas, 1999-2005

8. Relations between $A$, turbidity and suspended-sediment concentration, $B$, streamflow and suspended-sediment concentration in linear space, $C$, turbidity and suspended-sediment concentration, and $D$, streamflow and suspended-sediment concentration in $\log _{10}$ space for U.S. Geological Survey streamgage on Little Arkansas River near Sedgwick, Kansas, 1999-2005

9. Comparison of turbidity and streamflow at the time of sample collection in $A$, linear space and in $B, \log _{10}$ space for U.S. Geological Survey streamgage on Little Arkansas River near Sedgwick, Kansas, 1999-2005

10. Results of simple linear regression analysis for $A$, turbidity and suspendedsediment concentration data, and a comparison of $B$, estimated suspendedsediment concentrations and regression residuals, and $C$, probability plot of residuals for U.S. Geological Survey streamgage on Little Arkansas River near Sedgwick, Kansas, 1999-2005

11. Results of simple linear regression analysis using log-transformed data for $A$, turbidity and suspended-sediment concentration data, and comparison of $B$, computed $\log _{10}$ suspended-sediment concentration and regression residuals, and $C$, probability plot of residuals for U.S. Geological Survey streamgage on Little Arkansas River near Sedgwick, Kansas, 1999-2005. 
12. Comparison of turbidity and suspended-sediment concentration model-calibration data and uncorrected and bias-corrected simple linear regression lines for U.S. Geological Survey streamgage on Little Arkansas River near Sedgwick, Kansas, 1999-2005

13. Comparison of measured and model-estimated suspended-sediment concentrations for U.S. Geological Survey streamgage on Little Arkansas River near Sedgwick, Kansas, 1999-2005

14. Comparison of streamflow in $A$, linear space and in $B, \log _{10}$ space to residuals from a simple linear regression analysis of turbidity and suspended-sediment concentrations for U.S. Geological Survey streamgage on Little Arkansas River near Sedgwick, Kansas, 1999-2005.

15. Comparison of measured and estimated suspended-sediment concentration and residuals in log space from $A$, simple and $B$, multiple linear regression models for U.S. Geological Survey streamgage on Little Arkansas River near Sedgwick, Kansas.

16. Model-calibration data set (water years 1999-2005) and new (water year 2006) turbidity and suspended-sediment concentration data for U.S. Geological Survey streamgage on Little Arkansas River near Sedgwick, Kansas.

17. Comparison of turbidity measurements from YSI turbidity models 6026 and 6136 in various solutions.

18. Relation between YSI 6026 and YSI 6136 turbidity sensor values, U.S. Geological Survey streamgage on Little Arkansas River near Sedgwick, Kansas, July 14, 2004, to August 26, 2005

\section{Tables}

1. Selected specifications for selected turbidity instruments.

2. Statistical summary of model-calibration data set for U.S. Geological Survey streamgage on Little Arkansas River near Sedgwick, Kansas, January 1999December 2005

3. Diagnostic statistics of linear regression for evaluation and comparison of regression models

4. Expressions of simple linear regression and multiple linear regression models for U.S. Geological Survey streamgage on Little Arkansas River near Sedgwick, Kansas 


\section{Conversion Factors}

\begin{tabular}{|c|c|c|}
\hline Multiply & By & To obtain \\
\hline \multicolumn{3}{|c|}{ Length } \\
\hline micrometer $(\mu \mathrm{m})$ & $3.937 \times 10^{-5}$ & inch (in.) \\
\hline nanometer $(\mathrm{nm})$ & $3.937 \times 10^{-5}$ & inch (in.) \\
\hline \multicolumn{3}{|c|}{ Area } \\
\hline square mile $\left(\mathrm{mi}^{2}\right)$ & 2.590 & square kilometer $\left(\mathrm{km}^{2}\right)$ \\
\hline \multicolumn{3}{|c|}{ Rate } \\
\hline cubic foot per second $\left(\mathrm{ft}^{3} / \mathrm{s}\right)$ & 0.02832 & cubic meter per second $\left(\mathrm{m}^{3} / \mathrm{s}\right)$ \\
\hline ton per day (ton/d) & 0.9072 & metric ton per day \\
\hline ton per second (ton/s) & 0.9072 & megagram per second $(\mathrm{Mg} / \mathrm{s})$ \\
\hline
\end{tabular}

\section{Water-Quality Units}

Chemical concentration is given in units of milligrams per liter $(\mathrm{mg} / \mathrm{L})$. Milligrams per liter are units expressing the mass of solute per unit volume (liter) of water. Milligrams per liter are equivalent to parts per million.

\section{Acronymns and Abbreviations}

$\begin{array}{ll}\leq & \begin{array}{l}\text { less than or equal to } \\ \text { greater than }\end{array} \\ \text { ADAPS } & \text { Automated Data Processing System (U.S. Geological Survey) } \\ \text { ANCOVA } & \text { analysis of covariance } \\ \text { ASTM } & \text { American Society for Testing and Materials } \\ \text { AU } & \text { attenuation units } \\ \text { BCF } & \text { bias correction factor } \\ \text { BU } & \text { backscatter units } \\ C_{p} & \text { Mallow's } C_{p} \\ \text { DD } & \text { data descriptor } \\ \text { DECODES } & \text { Device Conversion and Delivery System (U.S. Geological Survey) } \\ \text { DV } & \text { daily value } \\ e_{i} & \text { residual error } \\ \text { FAU } & \text { formazin attenuation units } \\ \text { FBU } & \text { formazin backscatter units } \\ \text { FNMU } & \text { formazin nephelometric multibeam units } \\ \text { FNRU } & \text { formazin nephelometric ratio units } \\ \text { FNU } & \text { formazin nephelometric units } \\ \text { GCLAS } & \text { Graphical Constituent Loading Analysis System (U.S. Geological Survey) } \\ \text { ISO } & \text { International Organization for Standardization } \\ \log _{10} & \text { base-10 logarithm } \\ \text { MLR } & \text { multiple linear regression } \\ M S P E & \text { model standard percentage error } \\ & \end{array}$




\section{Acronymns and Abbreviations-Continued}

$\begin{array}{ll}\text { MVUE } & \text { minimum variance unbiased estimator } \\ \text { NTMU } & \text { nephelometric turbidity multibeam units } \\ \text { NTRU } & \text { nephelometric turbidity ratio units } \\ \text { NTU } & \text { nephelometric turbidity units } \\ \text { NWIS } & \text { National Water Information System (U.S. Geological Survey) } \\ \text { OBS } & \text { optical backscatter } \\ \text { OLS } & \text { ordinary least squares } \\ \text { PPCC } & \text { probability plot correlation coefficient } \\ \text { PRESS } & \text { prediction error sum of squares } \\ \text { QWDATA } & \text { U.S. Geological Survey water-quality database } \\ r & \text { correlation coefficient } \\ R^{2} & \text { coefficient of determination } \\ R_{a}^{2} & \text { adjusted coefficient of determination } \\ \text { RDB } & \text { relational database } \\ R M S E & \text { root-mean-squared error } \\ \text { SLR } & \text { simple linear regression } \\ S S C & \text { suspended-sediment concentration } \\ S S L & \text { suspended-sediment load } \\ T S S & \text { total suspended solids } \\ \text { USEPA } & \text { U.S. Environmental Protection Agency } \\ \text { USGS } & \text { U.S. Geological Survey } \\ \text { UV } & \text { unit value } \\ \text { VIF } & \text { variance inflation factor } \\ \text { WSC } & \text { Water Science Center (U.S. Geological Survey) } \\ \text { YSI } & \text { YSI Inc. (Yellow Springs, Ohio) } \\ & \\ \text { PSL } & \end{array}$





\title{
Guidelines and Procedures for Computing Time-Series Suspended-Sediment Concentrations and Loads from In-Stream Turbidity-Sensor and Streamflow Data
}

\author{
By Patrick Rasmussen, John R. Gray, G. Douglas Glysson, and Andrew C. Ziegler
}

\section{Abstract}

In-stream continuous turbidity and streamflow data, calibrated with measured suspended-sediment concentration data, can be used to compute a time series of suspended-sediment concentration and load at a stream site. Development of a simple linear (ordinary least squares) regression model for computing suspended-sediment concentrations from instantaneous turbidity data is the first step in the computation process. If the model standard percentage error (MSPE) of the simple linear regression model meets a minimum criterion, this model should be used to compute a time series of suspended-sediment concentrations. Otherwise, a multiple linear regression model using paired instantaneous turbidity and streamflow data is developed and compared to the simple regression model. If the inclusion of the streamflow variable proves to be statistically significant and the uncertainty associated with the multiple regression model results in an improvement over that for the simple linear model, the turbidity-streamflow multiple linear regression model should be used to compute a suspended-sediment concentration time series. The computed concentration time series is subsequently used with its paired streamflow time series to compute suspended-sediment loads by standard U.S. Geological Survey techniques.

Once an acceptable regression model is developed, it can be used to compute suspended-sediment concentration beyond the period of record used in model development with proper ongoing collection and analysis of calibration samples. Regression models to compute suspended-sediment concentrations are generally site specific and should never be considered static, but they represent a set period in a continually dynamic system in which additional data will help verify any change in sediment load, type, and source.

\section{Introduction}

Collection, computation, storage, and publication of suspended-sediment concentrations (SSCs), suspend-sediment loads (SSLs), and related environmental data can be important parts of investigations to evaluate the effects of fluvial sediment on a water resource (Glysson, 1989a). Suspended sediment can adversely affect water supply, recreation, aquatic life, flood control, transportation, fisheries, reclamation, and navigation (Angino and O'Brien, 1968). The U.S. Environmental Protection Agency (2008) lists sediment and other solid-phase constituents to be the most prevalent source of impairment of the Nation's surface water.

Traditionally, SSC data have been derived from analytical results from physical samples collected by methods described by Edwards and Glysson (1999), Nolan and others (2005), and Gray and others (2008). SSL data have been computed from SSC and streamflow data by methods described by Porterfield (1972) and Koltun and others (1994, 2006). The traditional U.S. Geological Survey (USGS) computation technique presented by Porterfield (1972) is predicated on the availability of more frequent than daily (continuous) streamflow time-series data and a concurrent trace of SSC interpolated from physical samples, and where necessary, SSC estimates. Interpolated and estimated parts of a $S S C$ trace for a stream site can include periods during which a substantial cumulative fraction of the annual $S S L$ occurs. Hence, considerable hydrologic judgment often is required to compute sediment records by Porterfield's (1972) method.

Turbidity is an expression of the optical properties of a sample that causes light rays to be scattered and absorbed rather than transmitted in straight lines through the sample (Anderson, 2005; ASTM International, 2007). Turbid water results from the presence of suspended and dissolved matter such as clay, silt, finely divided organic matter, plankton, other microscopic organisms, organic acids, and dyes (ASTM International, 2007).

The magnitude of turbidity in streams, lakes, and estuaries is often proportional to SSC. When proportional, the turbidity-SSC relation can be quantified through linear regression analysis (Walling, 1977; Gilvear and Petts, 1985; Buchanan and Schoellhamer, 1995; Lewis, 1996; Christensen and others, 2000; Uhrich and Bragg, 2003; Lietz and Debiak, 2005; Rasmussen and others, 2005; Lee and others 2009). The turbidity-SSC regression model, in turn, can be used to compute $S S C$ values from turbidity data within the turbidity 
meter's measurement range. Continuously monitored turbidity data enable computation of a SSC time series that can be used with its paired streamflow time series to compute continuous $S S L$ without the routine need for interpolation or estimation.

When the turbidity-SSC model is deemed adequate, regression-computed $S S C$ can provide a more reliable and reproducible $S S C$ time series with smaller uncertainty values than either a sediment-transport curve using streamflow as the sole independent variable for computations of SSC (Rasmussen and other, 2005; Lee and others, 2008) or arguably with SSC data produced by Porterfield's (1972) computational method (for which there is no quantitative method for deriving uncertainty). When the turbidity-SSC model is deemed inadequate, the addition of streamflow as a second model variable may result in an acceptable time series of SSC. The turbidity- or turbidity-and-streamflow-based computational scheme to produce SSC data has a number of advantages over that of Porterfield's (1972) method, as follows:

1. No subjective interpolation or estimation is required;

2. The computational procedure is precisely reproducible;

3. The scheme takes full advantage of the available database and computational resources; hence, it can substantially reduce the time and effort needed to compute $S S L$ records; and

4. Estimates of uncertainty can be computed for the SSC time series.

The turbidity- or turbidity-and-streamflow-based computational scheme also has advantages over the traditional sediment-transport curve method (Glysson, 1987). The reliability of $S S L$ computed from a transport curve depends on a number of factors, including the range of streamflow and SSC over which the data were collected to define the curve, the number and reliability of the concentration-discharge relations used to define the curve, and whether the data are representative of water and sediment loads for the computational period (Gray and Simões, 2008). Walling (1977) found that annual SSL computed using a sediment-transport curve could result in errors of as much as 280 percent, whereas errors in monthly SSL could range between +900 percent and -90 percent. Glysson and others (2001) compared SSL computed by the Porterfield (1972) method and a transport curve for 34 years of streamflow and suspended-sediment records at the USGS streamgage on the Rio Grande at Otowi Bridge, New Mexico. Daily SSL computed by these two techniques differed by as much as 4,000 percent, whereas the maximum difference in annual SSL computations was 526 percent. SSL for the 34-year period of record differed by 38 percent. Lee and others (2008) compared the uncertainty of annual SSL computed using a sediment-transport curve and a turbidity-SSC model at three sites near John Redmond reservoir, Kansas. The uncertainties associated with the annual SSL derived from sediment-transport curves ranged from 16-20 percent, whereas those derived from the turbidity-SSC model ranged from 1.1-3.2 percent.
Glysson and others (2001) observed that estimates of SSLs that are based on sediment-transport curves are subject to significant errors, in part because of the large range in SSC that can occur at any given water discharge. They concluded that, although a well-defined, carefully constructed and judiciously applied sediment-transport curve can be a useful tool for estimating SSL, SSL estimates derived from sediment-transport curves should not be considered a substitute for daily-sediment records computed by Porterfield's (1972) method. Lewis (1996) indicated that regression models using turbidity instead of streamflow improved the root-mean-squared errors of sediment rating curve estimates by 7 to 15 percent.

Hence, the use of a linear regression model to compute SSC from turbidity time-series data, and in some cases, turbidity and streamflow time-series data measured at a fixed location in a stream provide statistical estimates of uncertainty of SSC (Christensen and others, 2000). The use of a linear regression model, depending on the characteristics of the sediment in suspension, is likely a more accurate method for estimating a SSC time series than either the Porterfield (1972) method or traditional transport-curve method (Walling, 1977; Horowitz and others, 2003; Putnam and Pope, 2003).

SSC computed from regression models can be used for a variety of purposes, including use to describe variability in suspended-sediment conditions, to evaluate $S S C$ relative to water-quality criteria and water-resource management goals, and to compare the SSC and SSL characteristics among watersheds. Computed $S S C$ and streamflow data in riverine applications can be used to compute $S S L$ to reservoirs, which in turn can be used to infer loss of reservoir capacity. Computed SSC and SSL also can be used in the study of channel morphology and basic process analysis of sediment sources. Also, by relating the continuous, time-series turbidity data to the sampled SSC, it may be possible to identify the sources and timing of sediment transport more accurately than on the basis of periodic sample collection. Subsequently, computed daily, monthly, seasonal, and annual SSL can be used to assess differences in fluvial-sediment characteristics between basins as a function of hydrologic conditions, contributing drainage area, land use, sediment sources, and (or) human activity. Turbidity time-series data also can be used to compute a variety of constituent concentrations - for example, total nitrogen and total phosphorus (Rasmussen and others, 2005) and indicator bacteria (Rasmussen and Ziegler, 2003) that correlate well with SSC, which in turn can be used to compute loads of those constituents.

Historically, most State agencies have collected samples for analyses of total suspended solids (TSS) in lieu of SSC samples (Pruitt, 2003). This is largely a consequence of the fact that the U.S. Environmental Protection Agency presently only recognizes the TSS analytical method (American Public Health Association, American Water Works Association, and Water Pollution Control Federation, 2005). TSS data tend to be biased low, particularly when sand constitutes more than about 20 percent of the mass of the water-sediment mixture (Gray and others, 2000; and Glysson and others, 2000, 2001). For 
systems that convey primarily silt- and clay-sized sediment in suspension, Christensen and others (2000) and Rasmussen and others (2008) have used turbidity-TSS models to compute TSS values with acceptable uncertainties. However, TSS data are acceptable alternatives to SSC data only after being conclusively documented in a published report that the TSS data can adequately represent $S S C$ data over the range of expected flows at a site (U.S. Geological Survey, 2000).

\section{Purpose and Scope}

This report provides guidelines and procedures for computing time series of SSC and SSL from time series of turbidity and streamflow data using a generally site-specific, simple or multiple regression model relating SSC from periodically collected in-stream water samples to in-stream turbidity measurements. Included is the requisite knowledge to:

1. Develop and evaluate an empirical statistical relation between turbidity and SSC measurements;

2. Compute time series of $S S C$ and $S S L$ from turbidity and streamflow time-series data; and

3. Maintain a long-term $S S C$ record.

Examples of applications of the analytical and computational methods described herein are provided using data from USGS streamgages in California, Florida, Kansas, and Oregon. Although this guidance is for application in a riverine environment, selected aspects of the guidelines may be adapted for use in lacustrine or estuarine applications.

References to principles of sediment transport, sampling techniques, and related field procedures, along with qualitycontrol procedures, are presented because an understanding of these principles and procedures is fundamental to the computation of time-series suspended-sediment records. Concepts, statistical procedures, and techniques are presented for computing SSC and SSL time series. Material in this report includes procedures and techniques to maintain a multiyear SSC time series and to prepare suspended-sediment data for public dissemination. Selected duplication of material contained in other publications and guidelines is necessary and intentional to provide guidance for computing SSC and SSL from turbidity and streamflow data. Specific USGS guidance on methods for computing and storing computed suspendedsediment data in the USGS National Water Information System (NWIS) database is presented.

\section{Related Guidelines}

Porterfield (1972) describes two basic types of sediment records - daily and periodic - calculated from sampled SSC and using gage height and (or) streamflow data to synthesize the $S S C$ trace for unsampled periods. Daily records are prepared for sites where sufficient determinations of SSC and streamflow are obtained to enable computation of daily $S S L$
(Porterfield, 1972). The end product is a tabulation of daily time-weighted mean SSC, SSL, and, in many cases, periodic determinations of particle-size distributions of suspended sediment and bed material. These are combined with other hydrologic data and released, usually by water year (October 1 through following September 30), by the USGS in stream-site data sheets for specific States or in the Open-File or Scientific Investigation Report series. Periodic records are prepared for sites where frequency of determination of SSC and (or) streamflow are insufficient to justify computation of daily $S S L$ or where only miscellaneous samples are collected infrequently. In addition to publication of the records, the data and supporting documentation on computations are maintained on file in the USGS Water Science Centers and are available for examination or for use in interpretative reports and research.

Wagner and others (2006) provide basic guidelines and procedures used by USGS personnel for operating water-quality monitors, including site selection, field procedures, calibration of continuous water-quality monitors, record computation and review, and data reporting. In addition, Wagner and others (2006) present methods for servicing fixed-location waterquality monitors (including turbidity sensors) in freshwater environments and estuaries. Alternative methods for servicing monitors also are included. These basic guidelines are minimal requirements that may be modified to meet local environmental conditions or specific study objectives. Knowledge of monitoring-equipment operation and first-hand knowledge of the salient aspects of the watershed form the core of the data-evaluation process. Record-computation procedures presented in Wagner and others (2006) provide a uniform set of minimum requirements for computing water-quality records. Examples of the application of scientific judgment in the evaluation of data records are presented and are, by necessity, site specific. Other specific examples also are included to demonstrate the range of environmental conditions that affect the evaluation process.

Equipment and procedures for collection and measurement of fluvial sediment are described by Edwards and Glysson (1999), which contains two major sections regarding suspended-sediment equipment and techniques that are germane to developing turbidity/suspended-sediment relations. The "Sediment-Sampling Equipment" section includes information on the characteristics and limitations of various models of Federal Interagency Sedimentation Project (2008) isokinetic, depth- and point-integrating samplers (Davis, 2005), non-isokinetic single-stage samplers, automatic pumping samplers, and selected support equipment. The "SedimentSampling Techniques" section in Edwards and Glysson (1999) includes information on sediment-discharge measurements, including collection of representative samples, characteristics of sampling sites, equipment selection relative to the sampling conditions and needs, depth- and point-integration sampling techniques, surface and dip sampling, determination of sampler transit rates, sampling programs, and cold-weather sampling. The sediment-sampling equipment and techniques sections in Edwards and Glysson (1999), the subject matter of 
which is also the focus of Nolan and others (2005) and Gray and others (2008), provide the fundamental information for collecting representative water-sediment samples. The derived SSC data, in turn, are used in correlations to turbidity. A more detailed description of suspended-sediment data-collection techniques is beyond the scope of this report.

Although streamflow computations can be accomplished by several techniques depending on site and equipment characteristics, they usually entail collection of stage records along with periodic streamflow measurements. Stage records are obtained from a water-stage recorder. Streamflow measurements usually are made with a current meter (Rantz and others, 1982; Kennedy, 1984) or acoustic Doppler current profiler (Lipscomb, 1995; U.S. Geological Survey, 2002). The methods are consistent with the American Society for Testing and Materials (ASTM) standards and generally follow the standards of the International Organization for Standardization (ISO). A more detailed description of streamflow time-series computation is beyond the scope of this report.

Helsel and Hirsch (2002) provide a stand-alone text of applied statistical methods for hydrology. Their chapters "Simple Linear Regression" and "Multiple Linear
Regression" are cited throughout this guide and are essential for understanding and performing the statistical procedures presented.

\section{Types of Turbidity Sensors}

There are many methods for quantifying water clarity, including Secchi and black disks, laser diffraction (Gray and others, 2003; Gray and Gartner, 2009; Gray and Gartner, in press), digital-optic techniques (Gray and others, 2003; Gooding, in press) and optical light scattering and absorption techniques (table 1; Gray and others, 2003; Rasmussen and others, in press). The techniques in this report are predicated on use of either of two types of turbidity sensors that are based on nephelometric or optical-backscatter (OBS) principles and are commonly used to measure turbidity for the purposes of computing SSC (Gray and Gartner, 2006). These sensors are designed for extended in-situ deployment, are relatively inexpensive, and are either self recording or produce signals compatible with a data logger.

Table 1. Selected specifications for selected turbidity instruments (Anderson, 2005).

\begin{tabular}{|c|c|c|c|c|}
\hline Light source & $\begin{array}{l}\text { Multiple or single } \\
\text { light sources }\end{array}$ & Detection angle & $\begin{array}{c}\text { Single or multiple } \\
\text { detectors }\end{array}$ & Designated units \\
\hline $\begin{array}{l}\text { White or broadband } \\
\qquad(400-680 \text { nanometers })\end{array}$ & Single & 90-degree detection angle & Single & $\begin{array}{l}\text { NTU (nephelometric } \\
\text { turbidity unit) }\end{array}$ \\
\hline $\begin{array}{l}\text { White or broadband } \\
\qquad(400-680 \text { nanometers })\end{array}$ & Single & 90-degree detection angle & $\begin{array}{l}\text { Multiple detectors, } \\
\text { ratio compensation }\end{array}$ & $\begin{array}{l}\text { NTRU (nephelometric } \\
\text { turbidity ratio unit) }\end{array}$ \\
\hline $\begin{array}{l}\text { White or broadband } \\
\qquad(400-680 \text { nanometers })\end{array}$ & Single & $\begin{array}{l}\text { 30- (plus or minus } 15 \text { ) degree } \\
\text { detection angle (backscatter) }\end{array}$ & Single & BU (backscatter unit) \\
\hline $\begin{array}{l}\text { White or broadband } \\
\text { (400-680 nanometers) }\end{array}$ & Single & $\begin{array}{l}\text { 180-degree detection angle } \\
\text { (attenuation) }\end{array}$ & Single & AU ( attenuation unit) \\
\hline $\begin{array}{l}\text { White or broadband } \\
\qquad(400-680 \text { nanometers })\end{array}$ & Multiple & $\begin{array}{l}\text { Detectors at } 90 \text { degrees and pos- } \\
\text { sibly other angles to each beam }\end{array}$ & Multiple & $\begin{array}{l}\text { NTMU (nephelometric } \\
\text { turbidity multibeam unit) }\end{array}$ \\
\hline $\begin{array}{l}\text { Near infrared } \\
\quad(780-900 \text { nanometers }) \\
\text { or monochrome }\end{array}$ & Single & 90-degree detection angle & Single & $\begin{array}{l}\text { FNU (formazin } \\
\text { nephelometric unit) }\end{array}$ \\
\hline $\begin{array}{l}\text { Near infrared } \\
\quad(780-900 \text { nanometers }) \\
\text { or monochrome }\end{array}$ & Single & $\begin{array}{l}\text { 30- (plus or minus 15) degree } \\
\text { detection angle (backscatter) }\end{array}$ & Single & $\begin{array}{l}\text { FBU (formazin backscatter } \\
\text { unit) }\end{array}$ \\
\hline $\begin{array}{l}\text { Near infrared or } \\
\text { monochrome }\end{array}$ & Single & $\begin{array}{l}\text { 180-degree detection angle } \\
\text { (attenuation) }\end{array}$ & Single & $\begin{array}{l}\text { FAU (formazin attenuation } \\
\text { unit) }\end{array}$ \\
\hline $\begin{array}{l}\text { Near infrared } \\
\text { (780-900 nanome- } \\
\text { ters) or monochrome } \\
\text { (including Great Lakes } \\
\text { Instruments, Inc., } \\
\text { 1992-Method 2) }\end{array}$ & Multiple & $\begin{array}{l}\text { Detectors at } 90 \text { degrees and pos- } \\
\text { sibly other angles to each beam }\end{array}$ & Multiple & $\begin{array}{l}\text { FNMU (formazin } \\
\text { nephelometric multibeam } \\
\text { unit) }\end{array}$ \\
\hline
\end{tabular}


Unlike absolute measurements of selected physical properties of water, such as specific conductance, $\mathrm{pH}$, temperature, or dissolved oxygen, turbidity is a relative index of scattering and absorption of light in water. Turbidity is not a direct measure of suspended particles in water but instead is a measure of the scattering and absorbing effect such particles have on light (Sadar, 1998). Anderson (2005) provides a review of available turbidity sensor technologies with a decision tree to select a suitable instrument for a specific site or application and guidelines for calibration, operation, quality-assurance procedures, and reporting of data. Several characteristics of the water and suspended-sediment mixture, such as particle size, shape, and color, can affect the optical measurement (Sadar, 1998; Davies-Colley and Smith, 2001; Ziegler, 2002a,b; Anderson, 2005; Downing, 2005, 2006). The effects of these characteristics are discussed in the section on "Factors Affecting Relation Between Turbidity and Suspended-Sediment Concentration."

\section{Nephelometry}

Nephelometry is the measurement of light scattering using a light detector 90 degrees from the incident light (U.S. Environmental Protection Agency, 1999). Nephelometric measurements reflect the collective optical properties of solution that cause light to be scattered or attenuated rather than transmitted in straight lines through the solution; the larger the amount of scatter or attenuation of light, the larger the value measured by the nephelometric turbidity meter. Nephelometric measurements typically are expressed in turbidity units defined by the light source, detection angle, and whether the sensor has single or multiple detectors (table 1). Approved methods (in 2008) for the measurement of turbidity include those that conform to at least three protocols. These are stated in: (1) U.S. Environmental Protection Agency (USEPA) Method 180.1 (U.S. Environmental Protection Agency, 1979), (2) ISO Method 7027 (International Organization for Standardization, 1999), and (3) standard methods recommended by the American Water Works Association and the Water Environment Federation (Clesceri and others, 1998).

Wagner and others (2006) describe methods for measuring turbidity with submersible-type (fig. 1) and nonsubmersible nephelometric sensors. The nephelometric measurements shown in the examples in this report were made with either an YSI 6026 or YSI 6136 turbidity probe (YSI Incorporated, 2003). These YSI sensors conform to the ISO Method 7027 and ASTM D-7315 measurement standards. Each has a light
$\boldsymbol{A}$

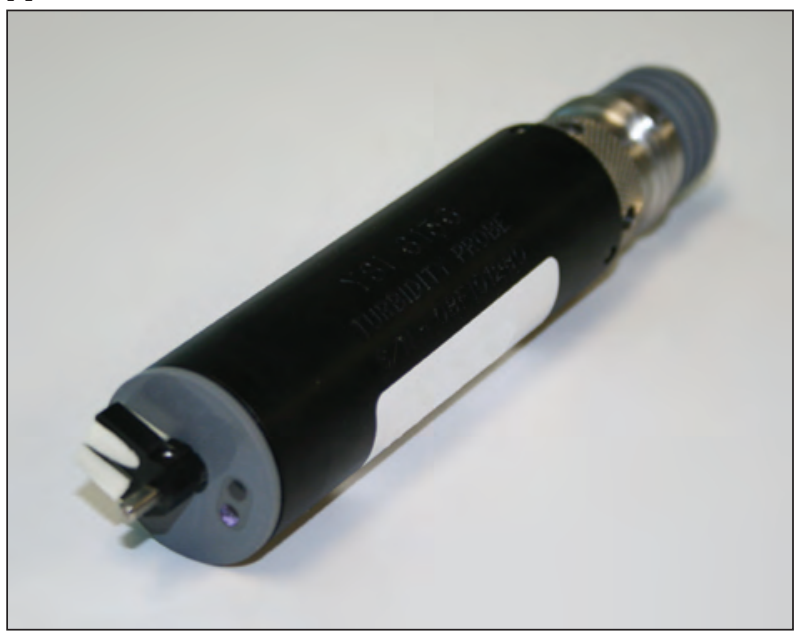

B

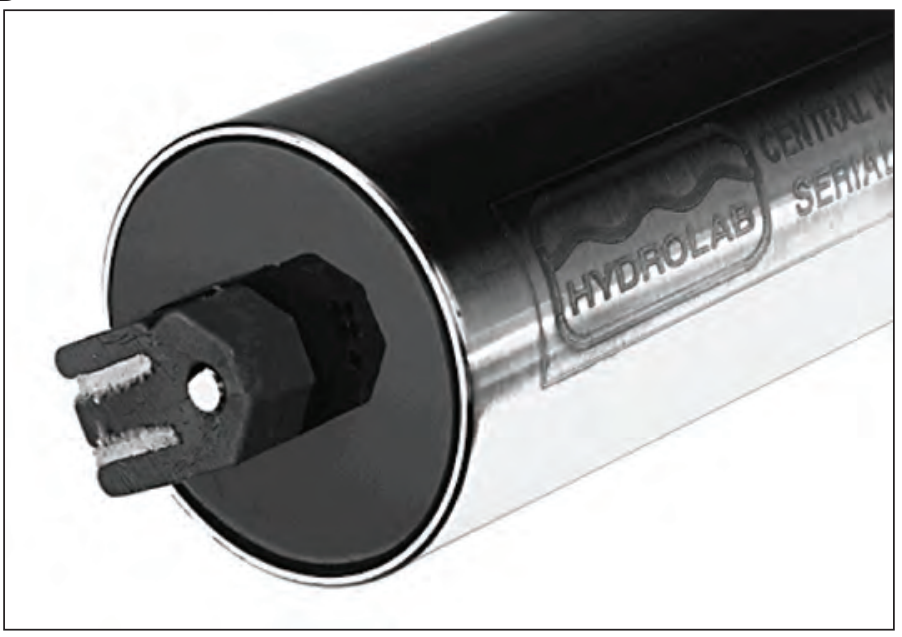

C

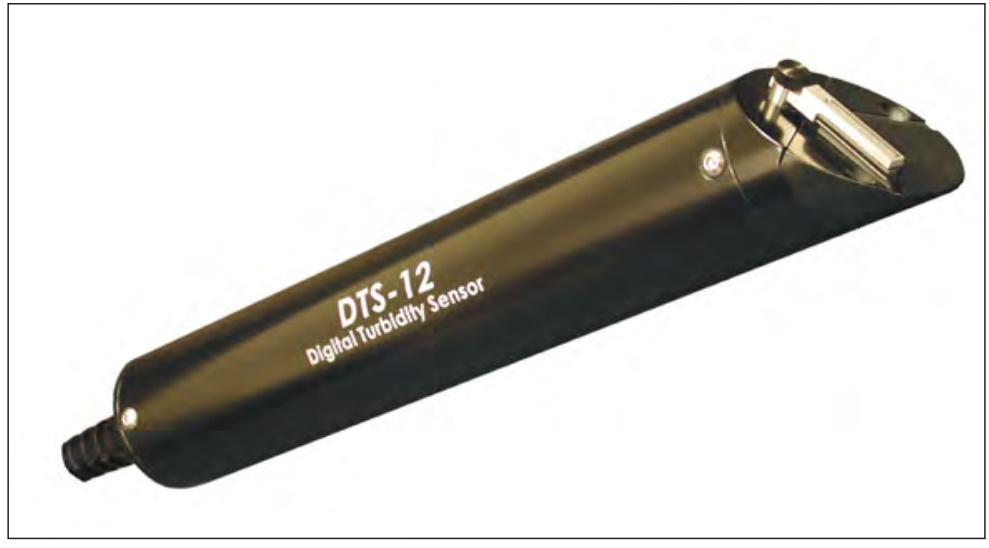

Figure 1. Three self-cleaning nephelometric turbidity sensors - $A, \mathrm{YSI}$ Incorporated (Yellow Springs, Ohio) model 6136 turbidity sensor, $B$, Hydrolab (Loveland, Colorado) self-cleaning turbidity sensor, and $C$, Forest Technology Systems (Blaine, Washington) model DTS-12 turbidity sensor. 
source of $860 \pm 30$ nanometers $(\mathrm{nm})$ with a single detector oriented at 90 degrees from the incident light path. Nephelometric readings from the YSI 6026, YSI 6136, and other turbidity sensors can be different and not directly equivalent (Sadar, 1998; Davies-Colley and Smith, 2001; Landers, 2003; YSI Incorporated, 2003; Ziegler, 2003a; Rasmussen and others, 2005). Different turbidity values, therefore, can be measured for an individual sample by different turbidity sensors conforming to the same standard method. See the "Changes to Turbidity Sensor Model or Type" section of this report for a discussion of data processing from different turbidity sensors.

\section{Optical Backscatter}

OBS sensors measure the same properties as nephelometric sensors, but the angle between the light source and the detector is less than 90 degrees. An OBS sensor is typically a cylinder utilizing an optical window from which light is both emitted and received (fig. 2; Downing and others, 1981; Downing, 1983). A pulse of either white or near-infrared light is transmitted through the optical window and is scattered or reflected by particles in front of the window in a 165-degree conical zone within some distance. Some of this scattered or reflected light is returned to the optical window where a receiver converts the backscattered light to a proportional voltage output. The relation of OBS sensor voltage output to SSC varies depending on the size, shape, and optical properties of the suspended sediment (Levesque and Schoellhamer,

\section{A}

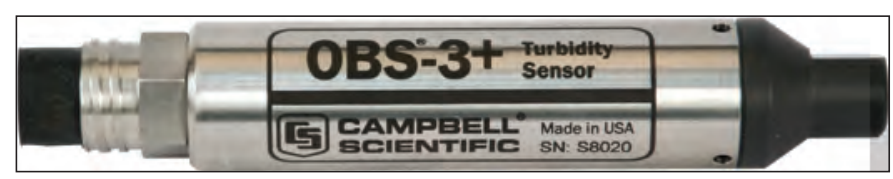

\section{B}

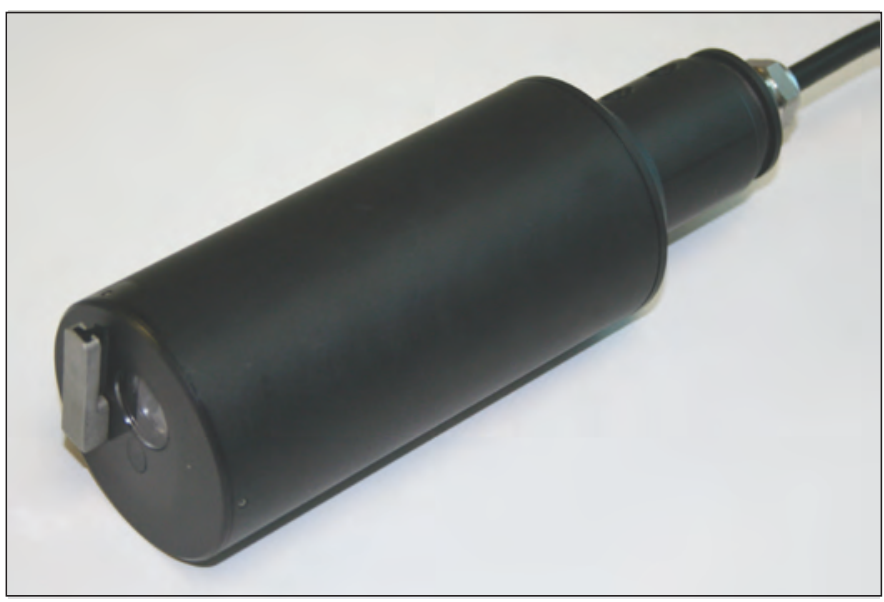

Figure 2. Optical backscatter sensors- $A, 0 B S 3+$ (Campbell Scientific Inc., Logan, Utah) and $B$, Hach (Loveland, Colorado) Solitax.
1995). Downing (2006) provides a thorough discussion of the history and use of OBS measurements to compute SSC. Typically, OBS sensors are used at locations where the nephelometric sensor maximum reporting level, ranging from 1,000 to 2,000 formazin nephelometric units (FNUs) or SSC values larger than 1,000 milligrams per liter (mg/L), are exceeded frequently.

\section{Relation of Turbidity to Suspended- Sediment Concentration}

A constituent concentration may be computed as a function of another measurement by means of linear regression models (Helsel and Hirsch, 2002). SSC, for example, can be computed from turbidity and (or) streamflow measurements by means of linear regression. The regression methods used in this guide are described in Helsel and Hirsch (2002) and are similar to those applied by Gilvear and Petts (1985), Lewis (1996), Christensen and others (2000), Uhrich and Bragg (2003), Lietz and Debiak (2005), and Rasmussen and others (2005).

To illustrate the techniques and methods discussed in these guidelines, turbidity, streamflow, and SSC data from USGS streamgage 07144100, Little Arkansas River near Sedgwick, Kansas, are used. A riverine example is presented because it is the most likely and common application of this method. Some of the methods discussed are not applicable to lacustrine or estuarine applications. Data sets and regression model examples of other riverine and estuarine data sets are provided in Appendix 1.

Steps in the procedure for computing time-series records of $S S C$ and $S S L$ are given in the checklist shown in figure 3. There are three major steps to completing the computation:

1. Compilation of a model-calibration data set of concurrent turbidity, streamflow, and SSC values;

2. Development of a linear regression model to compute instantaneous values of $S S C$; and

3. Computation and storage of instantaneous values of SSC and daily values of $S S L$.

Compilation, development, and computation methods are described in detail in the following sections.

\section{Model-Calibration Data Set}

Compilation of the model-calibration data set is the first step in the development of a linear regression model. The model-calibration data set consists of concurrent instantaneous in-stream measurements of turbidity and streamflow, and sampled SSC values that correspond to the paired turbiditystreamflow measurements. Appendix 2 discusses retrieval of these data types from the USGS National Water Information 
[NWIS, U.S. Geological Survey National Water Information System; ADAPS, U.S. Geological Survey Automated Data Processing System; QWDATA, U.S. Geological Survey water-quality database; SSC, suspended-sediment concentration; SSL, suspendedsediment load, $\mathrm{R}^{2}$, coefficient of determination; RMSE, root-mean-squared error; MSPE, model standard percentage error; PRESS, prediction error sum of squares; VIF, variance inflation factor; $R^{2} a$, adjusted coefficient of determination ; MVUE, minimum-variance unbiased estimator; ANCOVA, analysis of covariance]

\section{Checklist for time-series suspended-sediment records}

Worked Reviewed Approved

1) Compile model calibration data set

a) Retrieve data from NWIS

i) Approved time-series data: turbidity and streamflow (from ADAPS)

ii) Discrete sample data: SSC, sand-silt percentage (from QWDATA)

b) Assign turbidity and streamflow values to be used in regression

c) Plot raw data to identify potential outliers (turb against SSC)

d) Plot samples on turbidity and streamflow duration curves

e) Compile statistical summary of model calibration data set

f) Write model-calibration data-set summary in station analysis

2) Development of a regression model

a) Correlations and scatter plots of all data

b) Simple linear regression turbidity/SSC, untransformed and $\log _{10}$ transformed and regression diagnostics $\left(R^{2}, R^{2}\right.$, RMSE, PRESS, MSPE)

c) Determine proper transformation

d) Model residual plots

e) Plot model residual against streamflow, Julian day

f) Evaluate simple and multiple linear regression models (residual plots, VIF, partial F-test, $\mathrm{R}_{\mathrm{a}}^{2}$, PRESS, MSPE)

g) Bias correction factor (Duan or MVUE)

h) 90-percent prediction interval

i) Regression model summary in station analysis

3) Computation and storage of time-series suspended-sediment concentration and load record in NWIS
a) Set up data descriptors in ADAPS
b) Enter bias adjusted equation
c) Select period of suspended-sediment record for application of model
d) Compute SSC unit value and SSL daily values
e) Estimate missing SSC or SSL data
f) Evaluate period of record graphs
g) Update station analysis

4) Annual model validation
a) Plot calibration data set and recent annual data
b) Compare original model to model with additional data (ANCOVA)
c) Update model in ADAPS
d) Determine start date and time of new model

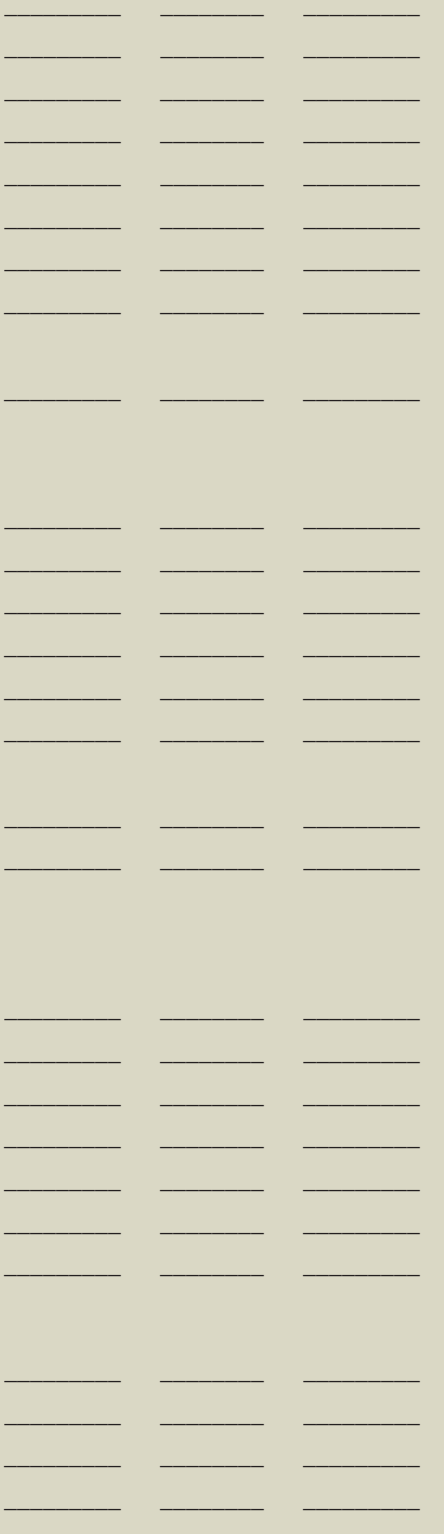

Figure 3. Checklist for development, verification, and approval of a regression model to compute suspendedsediment concentration and load time-series data. 
System (NWIS) database. The sampled SSC must be representative of the mean cross-sectional SSC value at the time of collection. The rationale for examination and quality assurance of the data are presented in the following paragraphs. The computation of turbidity and streamflow time-series data are assumed to have been completed by means of established USGS guidelines and procedures (Wagner and others, 2006; U.S. Geological Survey, variously dated). The guidance that follows is intended only to supplement procedures presented in Wagner and others (2006).

\section{Evaluation of Fixed-Location and Cross-Section Turbidity}

Comparisons of fixed-location and cross-section instream turbidity measurements should be part of the turbidity record analysis (Wagner and others, 2006). Fixed-location, in-stream (hereinafter referred to as "fixed-location") turbidity measurements collected concomitant with cross-section turbidity measurements should be retrieved from the "approved" time-series data set (U.S. Geological Survey, 2006, p. 20, 188-195). The turbidity cross-section measurements should be made with a properly cleaned and calibrated field turbidity sensor of the same make and model as the fixed-location turbidity sensor. Cross-section turbidity measurements are collected at several points across the stream routinely near the surface and periodically at different depths (Anderson, 2005). Those points at suspended-sediment sampling verticals are used for either the equal-width increment or equal-discharge increment methods (Edwards and Glysson, 1999; Nolan and others, 2005; Gray and others, 2008). These measurements are averaged and used in evaluations of the representativeness of data produced from fixed-location turbidity time-series measurements (fig. 4).

Large turbidity values warrant special evaluation. Although the values may be valid, spurious data can occur, including those recorded when turbidity exceeds the sensor's maximum recording level. Sensor-measurement truncation produces constant-value artifacts when in-stream turbidity levels exceed the maximum recording level of the sensor $(1,000-2,000 \mathrm{mg} / \mathrm{L}$ for most nephelometric sensors and $4,000-50,000 \mathrm{mg} / \mathrm{L}$ for most OBS). The maximum recording level is unique for each turbidity sensor and should be routinely quantified and documented for each sensor (Anderson, 2005). Because the maximum recording level of the sensor is reported for all turbidity values equal to or larger than the maximum recording level, truncation is manifested as a horizontal line or plateau in the temporal turbidity trace of plotted data (fig. 5). Routine calibration of the turbidity sensor can change the maximum recording level; therefore, turbidity measurements within about 10 percent of the maximum recording level should be evaluated to determine if those values are artifacts of truncation. Generally, these values should not be used as part of the model-calibration data set.

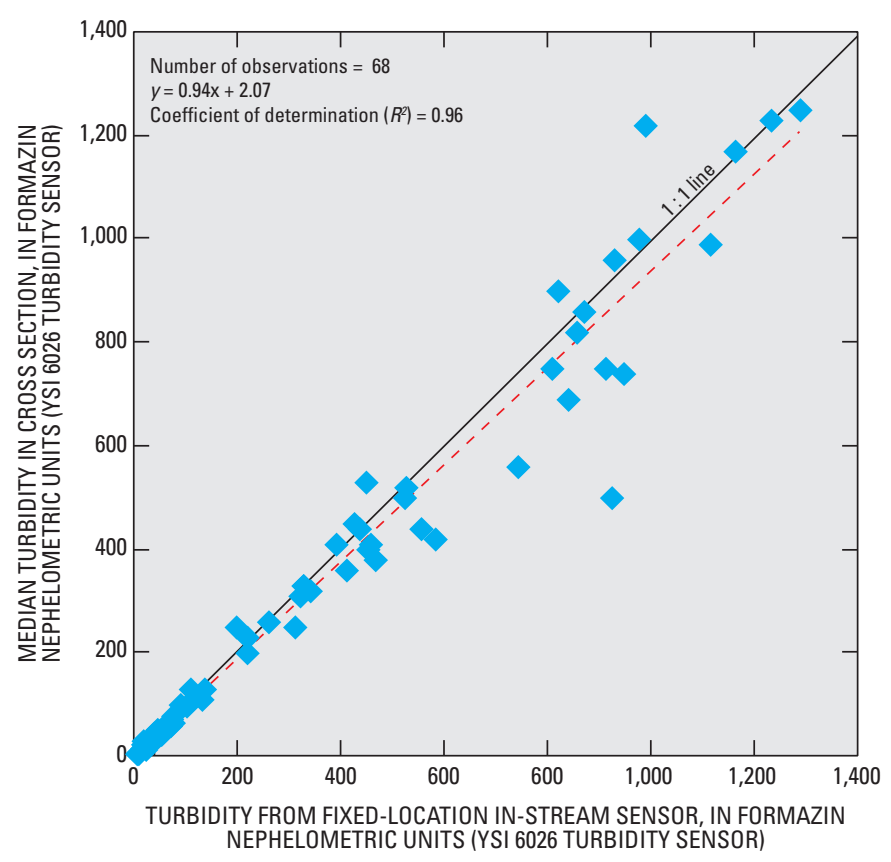

Figure 4. Comparison of fixed-location and median cross-section turbidity measurements for U.S. Geological Survey streamgage on Little Arkansas River near Sedgwick, Kansas, November 1998June 2005.

Exceptions should be clearly noted and fully explained as part of the summary in the station analysis (Appendix 1 at the back of this report). The use of turbidity sensors to compute $S S C$ at a site subject to frequent turbidity truncation may not be appropriate. OBS sensors should be used for streams where a significant percentage of SSL occurs at SSC values exceeding about 2,000 mg/L. However, currently (2009) most OBS sensors are not self cleaning and require more frequent routine maintenance.

\section{Determination of Turbidity and Streamflow Associated with Suspended-Sediment Concentrations}

Turbidity and streamflow corresponding to each SSC sample should be determined from the time-series data sets-preferably, time-weighted averages of turbidity and streamflow values recorded immediately before, immediately after, and during the SSC sample collection (fig. 5). The hydrographer should ensure that the turbidity and streamflow time-series data retrieved from the USGS time-series database, ADAPS, have a data-aging status of "approved" (U.S. Geological Survey, 2006, p. 20 and 188-195). Once turbidity and streamflow values have been determined for each SSC value, the hydrographer should compile a data set for statistical analyses. 


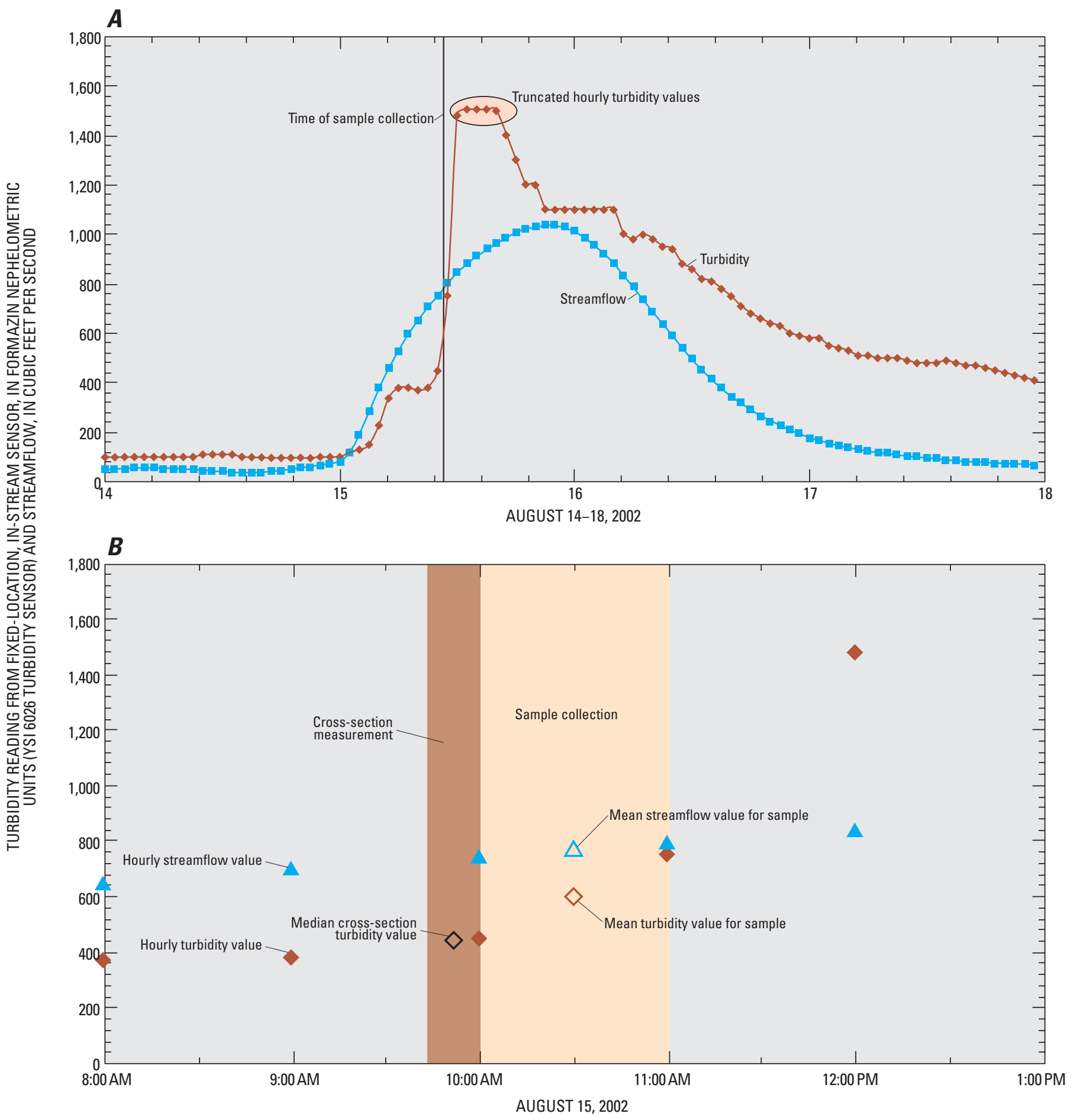

Figure 5. A, Time-series turbidity and streamflow data, August 14-18, 2002, and $B$, duration of cross-section turbidity and suspendedsediment sample collection, August 15, 2002, at U.S. Geological Survey streamgage on Little Arkansas River near Sedgwick, Kansas. 


\section{Identification of Outliers}

The development of a SSC regression model should be preceded by evaluation of a scatterplot of the turbidity and SSC calibration data. The hydrographer can sometimes discern outliers on the basis of the scatter of the data. Helsel and Hirsch (2002, p. 11, 31-34, 246-248) provide additional guidance on the identification and treatment of outliers.

Once an outlier is identified, the hydrographer should use all technically supportable analytical tools and methods to attempt to discredit the value in question. This includes:

1. Confirmation that the correct value was entered into the database;

2. Evaluation of laboratory analytical results; and

3. Review of the field notes to ensure that proper collection techniques were used or to otherwise identify factors that might lend credit to or that might refute the outlier.

Remove outliers from the analysis that can be discredited with a high degree of confidence. Conversely, if an outlier cannot be discredited, the hydrographer must determine the type of adjustment and document the attempts to verify the value in the station analysis summary (Appendix 1). Outliers that cannot be discredited may affect the analysis and may help the hydrographer better understand the relations among site turbidity, SSC, and streamflow. Numerous outliers may be indicative of problems with the measuring apparatus and (or) monitoring site that may in turn warrant corrective measures.

In the comparison of Little Arkansas River fixed-location turbidity measurements to SSC (fig. 6), five data points plotted outside the scatter and pattern of the other 68 data points. Inspection of field and laboratory notes and results of particlesize analyses indicated that these outliers should be either corrected or removed. One of the five outliers was derived from a sample that arrived at the laboratory with a loose bottle lid and an abnormally small sample volume. On the basis of this information, it was surmised that some sample water had leaked while most if not all of the sediment remained at the container's bottom, resulting in a spuriously large SSC. The discredited outlier was removed from the data set.

Values for two SSC samples that plot as outliers on opposite sides of the data scatter (identified as "Database entry errors for $S S C$ values" in figure 6) were evaluated. The field forms for these samples confirmed that turbidity values in the database matched the turbidity measurements made concomitant with SSC sample collection. However, a review of the analytical summaries for the SSC samples indicated that data-entry errors comprising misplaced decimal points resulted in one value appearing as 10-fold its true value and the other one-tenth of its true value. The two sample results were duly corrected in the database and replaced the erroneous values in the model-calibration data set.

Evaluation of the particle-size analyses performed on the suspended-sediment samples collected at relatively low streamflows indicated an abnormally large percentage of sand

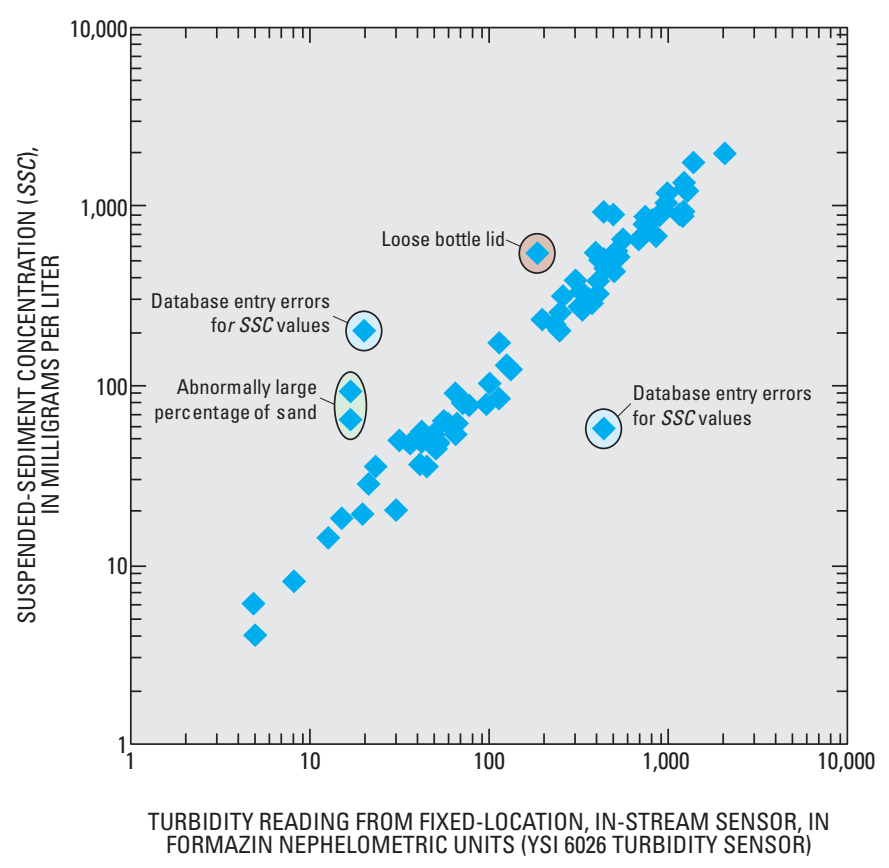

Figure 6. Comparison of turbidity to suspended-sediment concentration in water from U.S. Geological Survey streamgage on Little Arkansas near Sedgwick, Kansas, August 2000June 2005.

(particle sizes exceeding 63 micrometers $[\mu \mathrm{m}]$ ) for two other outliers. Typically, sand in samples collected at this site during similar low streamflow conditions constitutes no more than 2 percent of the sediment mass. Sand in these two samples constituted 10 and 30 percent of the dry sediment mass. Transport of sand at these low streamflows is unsupported by sedimentological theory and samples collected previously at this site. The outliers were deemed to be artifacts attributable to sampling error (inadvertently scooping sand-size bed material into the suspended-sediment sampler) and were removed from the data set.

A revised scatterplot identified no other data points that deviated sufficiently from the rest to justify further scrutiny.

\section{Adequacy of Model-Calibration Data Set}

An adequate model-calibration data set consists of an appropriate number of instantaneous, manual SSC samples and concurrent turbidity and streamflow measurements collected throughout the observed range of hydrologic conditions for the period of record (Glysson, 1989b; Rasmussen and others, 2002). The number of samples is often cited as the primary criterion for determining if a data set is adequate for computational purposes. Initially, approximately monthly samples collected over a 2- to 3-year period for the range of hydrologic conditions may be needed. Although the sample total is relevant, the distribution of the data over the range of observed turbidity, SSC, and streamflow values for the site is 
of paramount importance. A regression model developed from 15 samples more or less evenly distributed throughout the seasons and range of turbidity and streamflow at a site might result in a more representative model than one developed using a 50-sample data set where distribution of values defines only a limited time or range of the sedimentological conditions over which the model will be applied. Defining turbiditySSC relations during medium and high streamflow periods normally takes precedence over more equal spacing of data collection throughout the year, particularly if the purpose is to compute SSL. For example, where the number of site visits to collect manual samples is limited, sample collection should be skewed toward medium and higher flows. Regardless of the range of data values, the data points representing the extremes will have the greatest effect in determining the slope of the relation. For instance, erroneously large turbidity values during low streamflow and low SSC conditions can artificially increase the slope of the regression line.

Another factor to be considered when determining the adequacy of a data set is the amount of variability in the relation between turbidity and SSC. The larger the variability in the relation between turbidity and $S S C$ at a site, the greater the need is to collect more samples. Often, the hydrographer's challenge is to adequately characterize this variability with the fewest number of samples.

Serial correlation (also called autocorrelation) occurs when data are collected close enough in time that the regression assumption of data independence is violated. For instance, multiple samples may be collected during the rising and falling limb of a single runoff period. The serial correlation between the multiple data points can cause underestimation of the regression uncertainty. Helsel and Hirsch (2002, p. 250-251) present methods for identifying the presence of serial correlation. If serial correlation is detected, the solution is to randomly select a single data point from each group of correlated data. The single point should be used in the model-calibration data set. Alternately, Glysson (1987) describes a procedure by which mean SSC values are computed for each of several contiguous, discrete SSC intervals for the data set. These mean values are used to develop the regression equation.

Duration curves represent another tool to evaluate the distribution of SSC data and adapt subsequent sample-collection strategies. Ideally, turbidity and streamflow associated with the SSC samples should span the ranges of the time-series turbidity and streamflow values for the site (Rasmussen and others, 2002). For example, turbidity and streamflow values associated with discrete $S S C$ sample data are plotted on duration curves of turbidity and streamflow (fig. $7 A$ and $B$ ). The turbidity duration curve in figure $7 A$ was developed from hourly recorded turbidity measurements by the fixed-location sensor for the study period. The turbidity values associated with the SSC samples were plotted along the duration curve. Sample collection can be determined by closely monitoring the realtime turbidity and streamflow time-series data and optimizing sample-collection times to coincide with duration-curve segments undefined by sample values. As new SSC samples are collected, the hydrographer should add the corresponding turbidity and streamflow values to the duration-curve plots so that overall temporal distribution of samples can be assessed. Routine use of this tool will maximize the potential that the model-calibration data set optimally represents the range of turbidity and streamflow conditions.

Turbidity values for one or more years are sorted (or ranked) from smallest to largest to construct a turbidity duration curve from a turbidity time series. Then, exceedance probabilities are calculated for each turbidity value using Cunnane's plotting position (Cunnane, 1978; Helsel and Hirsch, 2002). The minimum turbidity-value duration percentage is 100 percent (all values within the data set are larger than or equal to this value). The maximum turbidity-value duration percentage is 0 percent (no values within the data set exceed this value). All the turbidity values within the data set are plotted according to calculated probabilities forming the turbidity duration curve. Symbols are plotted on the curve at the probability computed for turbidity values associated with each SSC sample. A streamflow duration curve can be constructed in a similar manner by substituting a streamflow time series for the turbidity time series. Streamflow duration curves representing the study period and, if different, the entire period of record provide study period and long-term comparisons.
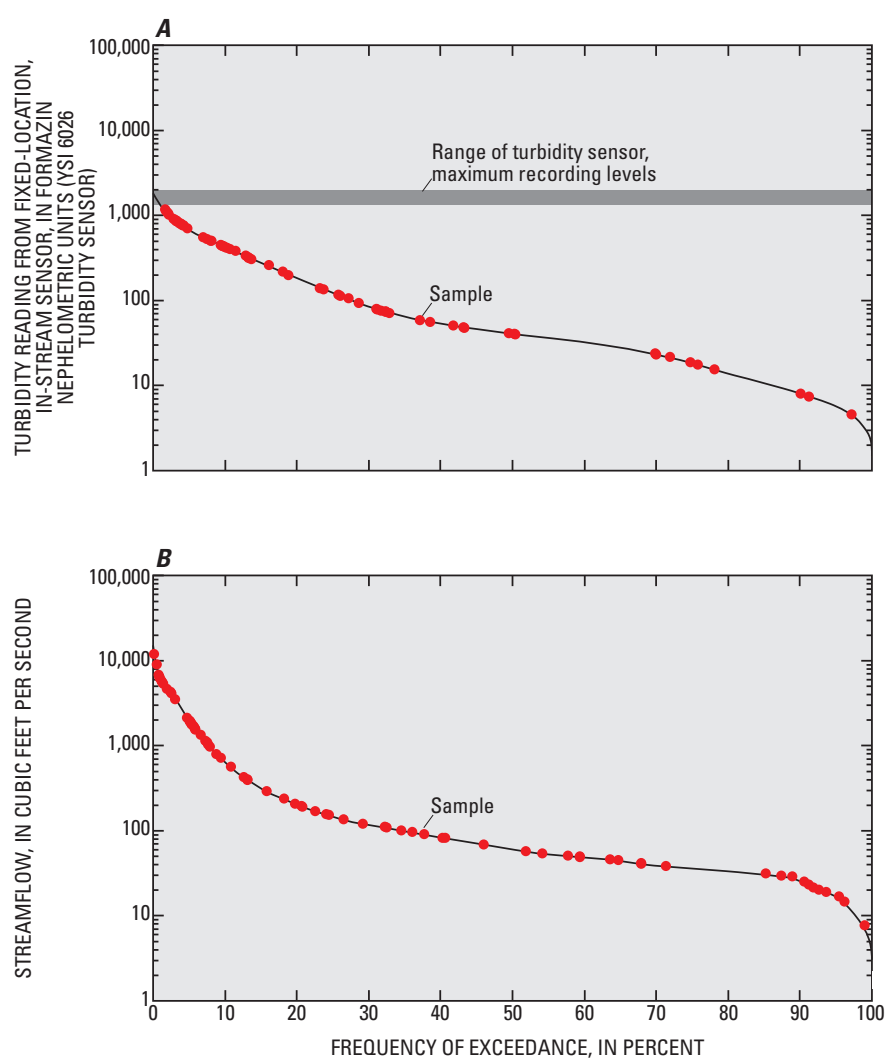

Figure 7. Duration curves for $A$, turbidity and $B$, streamflow and corresponding values associated with suspended-sediment concentration samples collected at U.S. Geological Survey streamgage on Little Arkansas River near Sedgwick, Kansas, 1999-2005. 


\section{Update of Station Analysis}

The station analysis for a stream site should be updated to summarize the data analyses performed. This summary should include the rationale behind:

1. Determination of turbidity and streamflow values associated with each SSC value;

2. Acceptance or exclusion of turbidity values near the sensor-dependent turbidity maximum recording level;

3. Identification of outliers of turbidity, streamflow, and (or) SSC values; and

4. Determination of the adequacy of the model-calibration data set using turbidity and streamflow duration curves.

Other information necessary to complete the station analysis includes a table of summary statistics of the modelcalibration data set. General statistics of the model-calibration data set and the time-series data set indicate the representativeness of the model-calibration data set (table 2). The minimum and maximum turbidity values for the model-calibration data set define the ideal limits for which the resulting regression model should be used to compute $S S C$ values. An understanding of suspended-sediment transport processes and sound hydrologic judgment-ideally drawn from years of experience-is required when deciding if values outside these limits are appropriate.

The hydrographer should review data plots, duration curves, and data statistics to evaluate the sufficiency of the model-calibration data set for developing a reliable regression model. If any of these categories are insufficient, the hydrographer may opt to suspend the model analysis and focus on additional sample collection so that the model-calibration data

Table 2. Statistical summary of model-calibration data set for U.S. Geological Survey streamgage on Little Arkansas River near Sedgwick, Kansas, November 1998-June 2005.

$\left[\mathrm{mg} / \mathrm{L}\right.$, milligrams per liter; FNU, formazin nephelometric units; $\mathrm{ft}^{3} / \mathrm{s}$, cubic feet per second]

\begin{tabular}{|c|c|c|c|c|c|}
\hline \multirow[b]{2}{*}{$\begin{array}{l}\text { Summary } \\
\text { statistic }\end{array}$} & \multicolumn{3}{|c|}{$\begin{array}{l}\text { Calibration data set } \\
\text { (68 samples) }\end{array}$} & \multicolumn{2}{|c|}{$\begin{array}{c}\text { Time-series data } \\
\text { set }(61,200 \text { hourly } \\
\text { values })\end{array}$} \\
\hline & $\begin{array}{l}\text { Suspended- } \\
\text { sediment } \\
\text { concentra- } \\
\text { tion } \\
\text { (mg/L) }\end{array}$ & $\begin{array}{c}\text { Turbidity } \\
\text { (FNU) }\end{array}$ & $\begin{array}{c}\text { Stream- } \\
\text { flow } \\
\left(\mathrm{ft}^{3} / \mathrm{s}\right)\end{array}$ & $\begin{array}{c}\text { Turbidity } \\
\text { (FNU) }\end{array}$ & $\begin{array}{c}\text { Stream- } \\
\text { flow } \\
\left(\mathrm{ft}^{3} / \mathrm{s}\right)\end{array}$ \\
\hline Minimum & 4 & 4 & 8 & 1 & 3 \\
\hline Maximum & 1,250 & 1,300 & 12,000 & 2,000 & 15,000 \\
\hline Mean & 350 & 370 & 1,500 & 140 & 380 \\
\hline Median & 240 & 240 & 210 & 41 & 60 \\
\hline $\begin{array}{l}\text { Standard } \\
\text { deviation }\end{array}$ & 350 & 380 & 2,500 & 260 & 1,200 \\
\hline
\end{tabular}

set may better represent the range of the time-series data set. As new sample results are added to the model-calibration data set, these same steps can be used to evaluate how the new data enhance or otherwise alter the model.

\section{Regression Model Development}

The key elements for computing SSC time-series data from periodic instantaneous $S S C$, turbidity, and streamflow data are the type and goodness-of-fit of the regression model used in the computation. A number of quantifiable variables can be used to compute SSC in streams, including turbidity; hydrologic characteristics, including streamflow, stream stage, streamflow rise or fall, and rates of rise and fall; precipitation rate and intensity; and seasonality, sediment sources, and land use. The explanatory variables turbidity and streamflow generally are the most important in SSC regression analysis. Thus, these guidelines focus on turbidity and, to a lesser extent, streamflow as explanatory variables of SSC. A SLR model relating turbidity to $S S C$ is often sufficient for reliable computations of SSC. Criteria are provided for determining the sufficiency of a SLR model and for determining when a multiple linear regression (MLR) model relating both turbidity and streamflow to $S S C$ results in a significant improvement over the SLR model that is based on turbidity alone. Typically, addition of a streamflow variable is more likely to improve the turbidity-SSC regression as the percentage of the SSC that is sand-size or larger material (coarser than $63 \mu \mathrm{m}$ ) increases. Concepts for development and use of a SLR model to compute $S S C$ and, when appropriate, a MLR model as a function of turbidity and streamflow to compute $S S C$, are explained in the following sections. The following regression analysis is site-specific and applies to a single model-calibration data set. A comparison between sites and model-calibration data sets is beyond the scope of this report. Specifically excluded from these guidelines is use of a SLR model for routine computation of SSC solely from streamflow due to varying degrees of hysteresis common in the $S S C$-streamflow relation. Currently (2009), ADAPS is limited to only SLR models using turbidity for computing a more frequent than daily SSC time series (U.S. Geological Survey, 2003). For example, ADAPS cannot compute more frequent than daily SSC using streamflow or more than one explanatory variable.

There are a variety of approaches to building an appropriate model, including SLR and MRL (Helsel and Hirsch, 2002) and Kendell-Theil robust line (Granato, 2006). The following sections provide some general guidance on develop a linear regression model using turbidity and streamflow as explanatory $(x)$ variables and $S S C$ as the response $(y)$ variable. Linear regression is not only used to derive a final model to compute SSC but also is used in the intermediate steps to determine the final model form. The hydrographer may need to evaluate the performance of more than one intermediate regression model before determining the optimal model for computing SSC. Regression results are an effective means for 
evaluating whether or not variables should be transformed and which variables are necessary to best estimate the variability in SSC. The following sections describe methods by Helsel and Hirsch (2002) for deriving the optimal regression model for computing SSC. A detailed summary of SLR development for turbidity-SSC and evaluation of MLR for turbidity and streamflow-SSC is presented in example 1 of Appendix 1. Complete and detailed presentations of these regression methods are not presented in these guidelines and procedures but can be found in Helsel and Hirsch (2002, p. 221-263 and 295-321). S-Plus (Insightful Corporation, 2001) is the USGSsupported statistics software package for performing SLR and MLR analyses. Microsoft ${ }^{\circledR}$ Excel $^{\circledR}$ can be used, but results from Excel should always be verified with S-Plus derived results. Results from both software packages are provided in example 1 of Appendix 1.

\section{Correlation}

Correlation coefficients measure the strength of association between two variables (Helsel and Hirsch, 2002). The most commonly used measure of correlation is Pearson's $r$. This correlation also is called the linear correlation coefficient because $r$ measures the linear association between two variables (Helsel and Hirsch, 2002, p. 218). Measures of correlation have the characteristic of being dimensionless and scaled to lie in the range $-1 \leq r \leq 1$. When there is no correlation between two variables, $r=0$. When the increase or decrease in the variables is synchronous, $r$ is positive. When the variables vary in opposite directions, $r$ is negative. When one variable is a measure of time or location, correlation becomes a test for temporal or spatial trend, respectively.

Whenever a correlation coefficient is calculated, it should be presented with a scatter plot of the data. No single numerical measure can substitute for insights that can be gained from visual examination of such a plot. Scatter plots and correlations of turbidity, streamflow, and $S S C$ values are simple and convenient ways of identifying which of the variables are statistically related and whether transformation of the data might improve the relation between the explanatory and response variables (fig. 8). The hydrographer can get a better idea from a simple analysis of which or both of two variables - turbidity and streamflow-are superior for computing SSC. Generally, the closer the correlation coefficient is to 1 (perfect positive correlation), the stronger the association between variables.

For MLR, multicollinearity - a case of MLR in which the explanatory variables are themselves highly correlatedcan result in undesirable consequences for model results. Helsel and Hirsch (2002, p. 305) suggest computing a variance inflation factor (VIF) for measuring multicollinearity. The VIF for turbidity and streamflow is readily computed by using the coefficient of determination $\left(R^{2}\right)$ from the regression of turbidity on streamflow (equation 11.6 in Helsel and Hirsch, 2002, p. 305). A VIF larger than 10 (or a Pearson's $r$ larger than 0.95 between turbidity and streamflow) indicates multicollinearity between turbidity and streamflow, and suggests that the use of either variable would explain about the same amount of variability and that the two variables should not be used together as explanatory variables in a MLR (Helsel and Hirsch, 2002, p. 305-6). The scatter plot and VIF of data from the Little Arkansas River near Sedgwick, Kansas (fig. 9), suggest that turbidity and streamflow are not strongly multicollinear and could be used as explanatory variables in a MLR model to compute SSC.

\section{Simple Linear Regression for Computation of Suspended-Sediment Concentrations}

Values of a response variable can be expressed in terms of a single explanatory variable or many explanatory variables using linear regression models (Helsel and Hirsch, 2002). An explanatory variable such as turbidity can be used in a regression model to compute the response variable SSC. The most common estimation technique is SLR, as presented in chapter 9 of Helsel and Hirsch (2002). SLR models can be computed using many statistical software packages. SLR analysis of the Little Arkansas River model-calibration data set yields the plots shown in figure 10 using untransformed data and in figure 11 using $\log _{10}$-transformed data.

A list of diagnostics for linear regression can be used to evaluate various steps in the model- building process (Helsel and Hirsch, 2002, p. 226-7). The coefficient of determination adjusted $\left(R_{a}^{2}\right)$ for the number of explanatory variables (or, equivalently, the degrees of freedom) in the model indicates the fraction of variability in the response variable that is explained by the model. The root-mean-squared error (RMSE) is a measure of the variance between regression-computed and observed values. The RMSE is approximately equal to one standard deviation $(\sigma)$ or the 67-percent prediction interval and is expressed in the same units as the response variable. $R M S E$ expressed in log units is not directly comparable with $R M S E$ expressed in milligrams per liter. RMSE can be expressed as a percentage (Hardison, 1969), hereinafter referred to as the model standard percentage error (MSPE). $M S P E$ can be used to compare any regression model. For $R M S E$ expressed in $\log _{10}$ units, the MSPE interval is:

$$
\begin{aligned}
& \text { Upper MSPE }=\left(10^{\text {RMSE }}-1\right) \times 100, \text { and } \\
& \text { Lower MSPE }=\left(1-10^{- \text {RMSE }}\right) \times 100 .
\end{aligned}
$$

For RMSE expressed in milligrams per liter, the MSPE interval is:

$$
M S P E= \pm \frac{R M S E}{\bar{y}} \times 100
$$

where

$\bar{y} \quad$ is the mean of the response variable. 

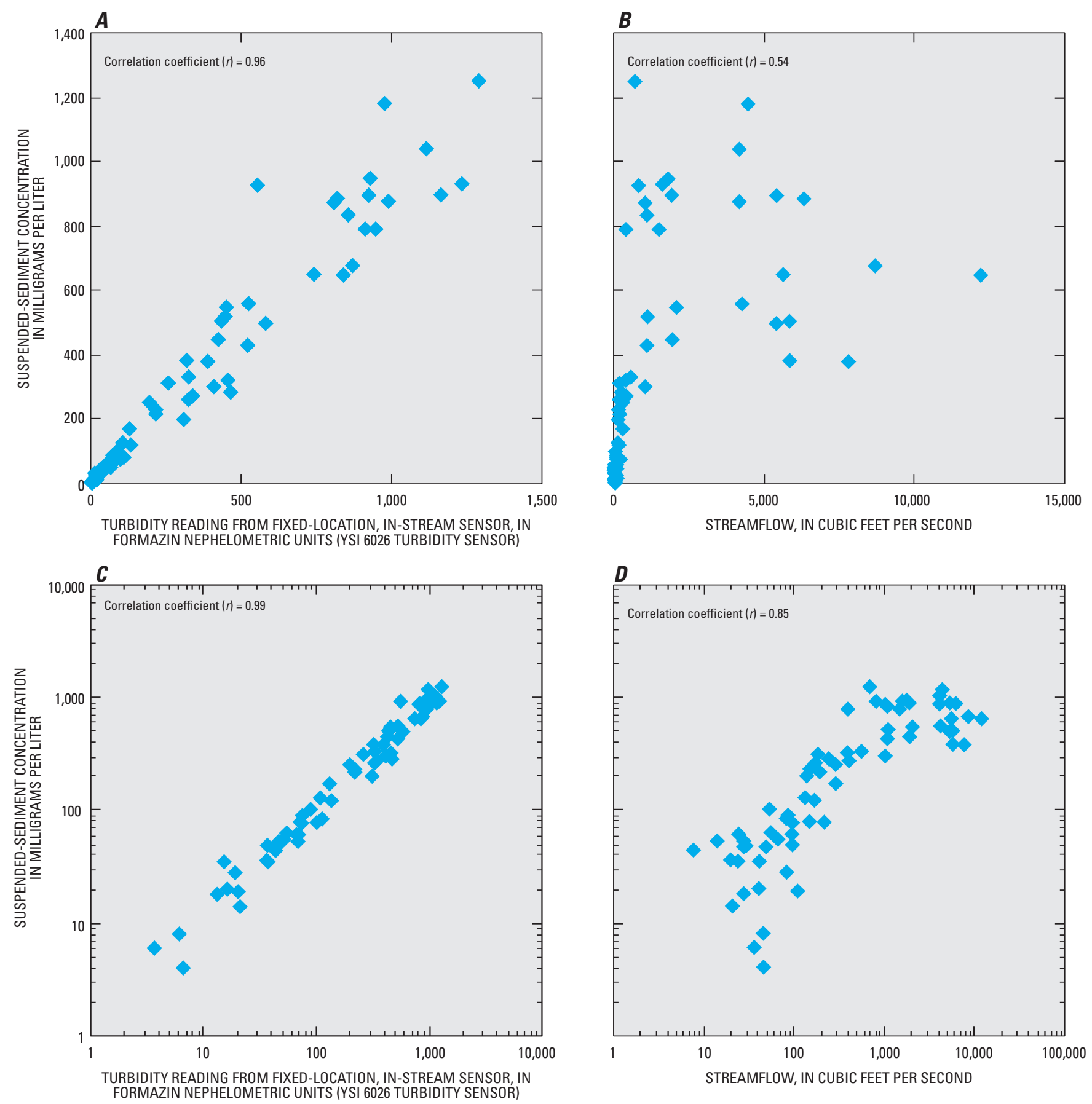

Figure 8. Relations between $A$, turbidity and suspended-sediment concentration, $B$, streamflow and suspended-sediment concentration in linear space, $C$, turbidity and suspended-sediment concentration, and $D$, streamflow and suspended-sediment concentration in $\log _{10}$ space for U.S. Geological Survey streamgage on Little Arkansas River near Sedgwick, Kansas, $1999-2005$. 


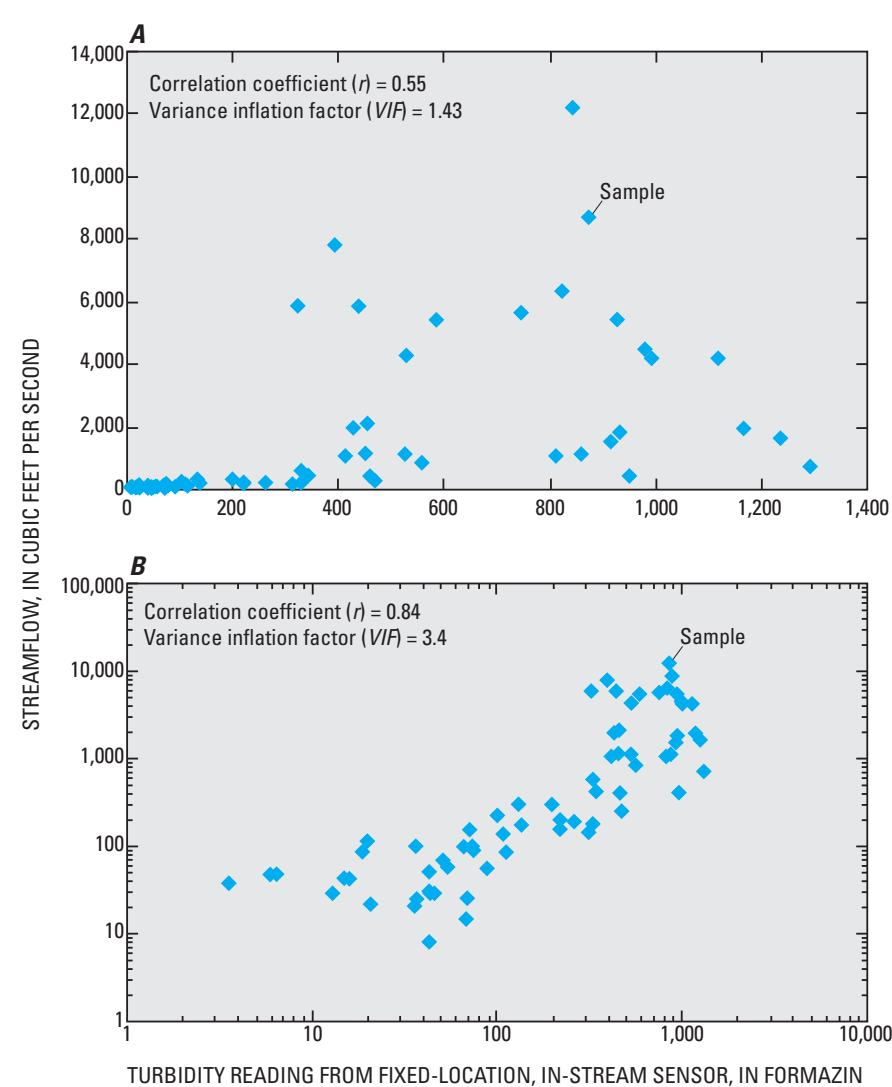
NEPHELOMETRIC UNITS (YSI 6026 TURBIDITY SENSOR)

Figure 9. Comparison of turbidity and streamflow at the time of sample collection in $A$, linear space and in $B, \log _{10}$ space for U.S. Geological Survey streamgage on Little Arkansas River near Sedgwick, Kansas, 1999-2005.

The lowest MSPE corresponds to the model with the least uncertainty associated with regression-computed values. The PRESS (prediction error sum of squares) statistic is one of the best measures of the quality of a regression model and also can be computed using RMSE (Helsel and Hirsch, 2002, p. 247). Table 3 presents when and how a diagnostic statistic can be used for comparison among regression models. Note that none of these diagnostic statistics can be used to compare regression with different response variables units.

\section{Transformation of Data}

The purposes for transformation of data prior to an analysis are to make the residuals more symmetric, linear, and homoscedastic (associated with a constant variance). Helsel and Hirsch (2002, p. 252-4) describe the rationale for and the results of data-set transformations. Serious problems can occur when regression models are developed and residuals do not possess the assumed characteristics of symmetry, linearity, and homoscedasticity. Comparisons of transformed and untransformed data and regression results are presented throughout this section so that the hydrographer can better understand how data transformation improves the computation of SSCs.

Base-10 logarithmic transformation is one of several mathematical functions that sometimes can be used to transform data sets so that the assumptions for linear regression analysis are met. Helsel and Hirsch (2002, p. 12-14) discuss other transformation options and characteristics. Logarithmic base-10 transformation has been shown to be effective in normalizing residuals of turbidity-SSC regressions. Hydrographers should start with base-10 logarithm transformation but are encouraged to experiment with other transformation options to determine if a different transformation of the dataset results in a model that better satisfies the assumed residual characteristics for regression analysis. Other considerations should include the ease of retransforming the results from the model, the bias associated with the retransformation, and rationale for complex transformations. As Helsel and Hirsch (2002) point out, it is better to choose a single transformation for data from several sites than it is to have custom transformations for every data set. The examples presented here use a logarithmic base-10 transformation of both the response and explanatory variables, which is equivalent to the power function regression performed on untransformed variables and used for many streamflow-SSC transport curves (Glysson, 1987; Curtis and others, 2006). From Helsel and Hirsch (2002), page 315.

"Should $y$ (SSC) be transformed? To decide whether to transform the $y$ variable, plot residuals against predicted values for the untransformed data. Compare this to a residuals plot for the best-transformed model, looking for three things:

Table 3. Diagnostic statistics of linear regression for evaluation and comparison of regression models (Helsel and Hirsch, 2002).

$\left[R^{2}\right.$, coefficient of determination; $R_{a}^{2}$, adjusted coefficient of determination; $R M S E$, root-mean-squared error; MSPE, model standard percentage error; $\uparrow$, maximize; $\downarrow$, minimize]

\begin{tabular}{|c|c|c|c|c|c|}
\hline Type of models being compared & $R^{2}$ & $R_{a}^{2}$ & RMSE & PRESS & MSPE \\
\hline Same response variable $(y)$ units & $\uparrow$ & $\uparrow$ & $\downarrow$ & $\downarrow$ & $\downarrow$ \\
\hline Differing response variable $(y)$ units & & & & & $\downarrow$ \\
\hline Same $y$ and varying number of $x$ variables & & $\uparrow$ & $\downarrow$ & $\downarrow$ & $\downarrow$ \\
\hline Should $y$ be transformed? & & & & & $\downarrow$ \\
\hline
\end{tabular}



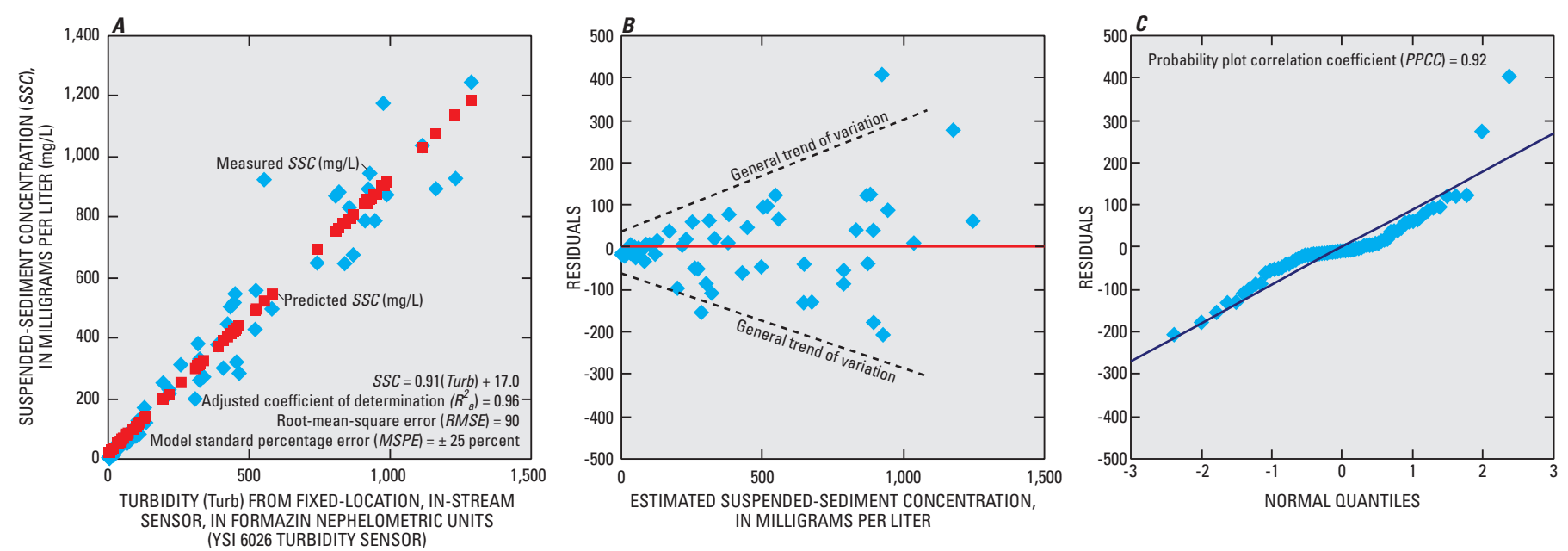

Figure 10. Results of simple linear regression analysis for $A$, turbidity and suspended-sediment concentration data, and a comparison of $B$, computed suspended-sediment concentrations and regression residuals, and $C$, probability plot of residuals for U.S. Geological Survey streamgage on Little Arkansas River near Sedgwick, Kansas, 1999-2005.
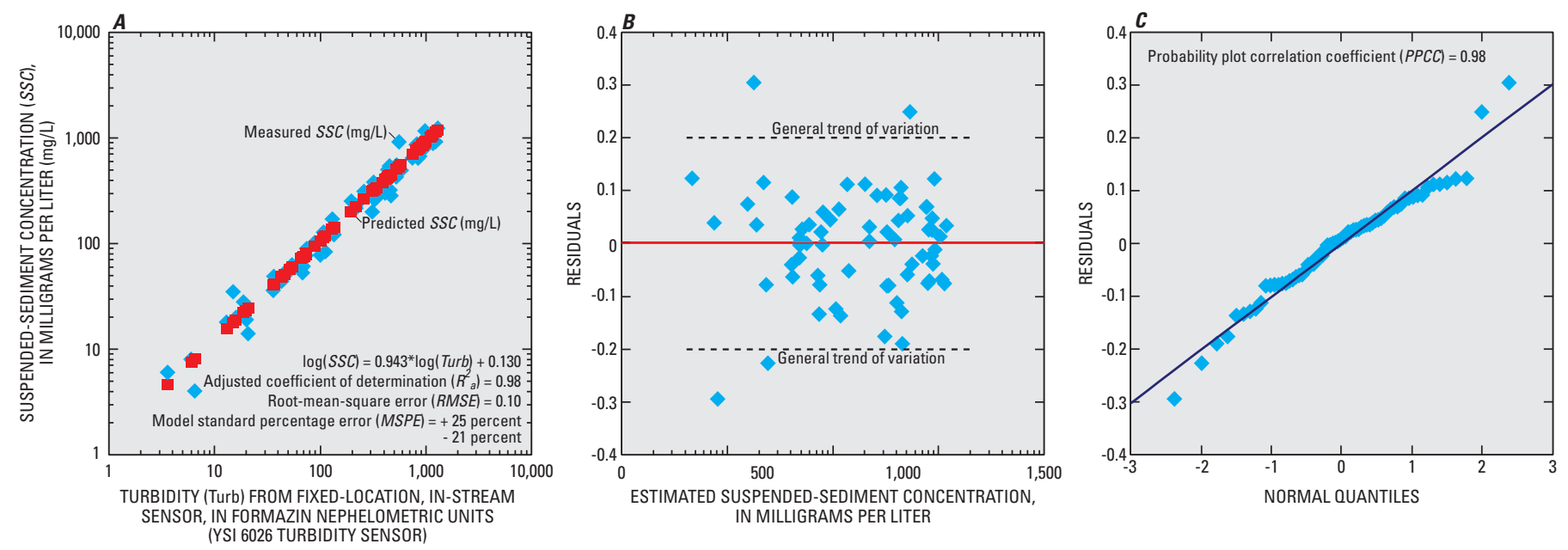

Figure 11. Results of simple linear regression analysis using log-transformed data for $A$, turbidity and suspended-sediment concentration data, and comparison of $B$, estimated $\log _{10}$ suspended-sediment concentration and regression residuals, and C, probability plot of residuals for U.S. Geological Survey streamgage on Little Arkansas River near Sedgwick, Kansas, $1999-2005$.

1. Constant variance across the range of the $y(S S C)$;

2. Normality of residuals; and

3. A linear pattern, not curvature, centered vertically around the zero residual line.

The statistics $R^{2}, R_{a}^{2}, R M S E$, and PRESS are not appropriate for comparison among models having different units of $y$.

Should $\boldsymbol{x}$ (or several $\boldsymbol{x}$ 's) be transformed? The decision about whether to transform an $x$ variable should be made using partial-residual plots. Check for the same three patterns of constant variance, normality, and linearity. Considerable help can be obtained from statistics such as $R_{a}^{2}$ (maximize it), or $R M S E$ or PRESS (minimize it). Many transformations can be rapidly checked with such statistics, but a residuals plot should always be produced and inspected prior to accepting or rejecting a transformation scheme."

\section{Model Residual Analysis}

Regression models are evaluated by examining the model residuals. Ordinary residuals are defined as the difference between the observed values and the model estimates (the term "model estimate" is used here because the values are estimates of actual samples or observed values). The residual error $\left(e_{i}\right)$ for the computed $S S C$ values should be random and, in theory, should be normally distributed with a mean of zero and a constant variance (Helsel and Hirsch, 2002). The residuals from a regression of $S S C$ on turbidity indicate how 
the model-estimated SSC varies from the observed SSC. A residual value of 0 indicates that the model-estimated SSC is equal to the observed value. A positive residual indicates that the observed value was larger than the estimated value, and a negative residual indicates that the observed value was less than the estimated value.

The variance of the residuals can be evaluated by plotting them against the model estimated SSC (figs. $10 B$ and $11 B$ ). The residuals plotted in figure $10 B$ indicate a heteroscedastic pattern (nonconstant variance; as indicated by the dashed lines) where the variability of the residuals increases as estimated SSC values increase, which suggests the need for some sort of variance stabilizing transformation of the response variable. The residuals plot for the $\log _{10}$-transformed regression (fig. 11B) indicates a homoscedastic pattern (constant variance) and a more normal distribution. Normality of residuals can be evaluated by plotting residuals on a normal-probability plot (figs. $10 \mathrm{C}$ and $11 \mathrm{C}$ ) and computing the probability plot correlation coefficient (PPCC; Helsel and Hirsch, 2002, p. 253). Non-normally distributed residuals will not be linear or equally distributed on a normal-probability plot and have a smaller PPCC. The probability plot for the $\log _{10}$-transformed regression provides a more linear, even distribution of residuals and a slightly larger PPCC than the residuals from the regression with untransformed variables (figs. $10 C$ and $11 C$ ). The plots in figures $10 B$ and $11 B$ confirm that $\log _{10}$ transformation provides more homoscedastic, normally distributed residuals.

\section{Simple Linear Regression Model and Bias Correction Factor}

The SLR model for the Little Arkansas River near Sedgwick, Kansas, for data collected from November 1998 to June 2005 is shown below with basic model information, regression coefficients, model diagnostics, and Duan's bias correction factor (Duan, 1983):

$$
\log _{10}(S S C)=0.943 \log _{10}(\text { Turb })+0.130,
$$

where

$$
\begin{gathered}
\text { SSC is suspended-sediment concentration, in } \\
\text { milligrams per liter, and } \\
\text { is turbidity, in formazin nephelometric units, } \\
\text { measured with YSI model } 6026 .
\end{gathered}
$$

\section{Model information:}

Number of measurements $=\mathbf{6 8}$,

root-mean-squared error $(R M S E)=\mathbf{0 . 1 0}$,

model standard percentage error $(M S P E)=+\mathbf{2 5 . 9}$ and

-20.6 percent,

90-percent prediction interval $= \pm \mathbf{4 1}$ percent,

adjusted coefficient of determination $\left(R_{a}^{2}\right)=\mathbf{0 . 9 8}$,

PRESS $=\mathbf{0 . 6 6 3}$.

Duan's bias correction factor $=\mathbf{1 . 0 3}$.

\section{Coefficients:}

\begin{tabular}{lcccl}
\hline & Value & $\begin{array}{c}\text { Standard } \\
\text { error }\end{array}$ & t-statistic & p-value \\
\hline Intercept & $\mathbf{0 . 1 3 0}$ & $\mathbf{0 . 0 4 1}$ & $\mathbf{3 . 0 2}$ & $\mathbf{0 . 0 0 3 5}$ \\
$\log _{10}$ (turbidity) & $\mathbf{0 . 9 4 3}$ & $\mathbf{0 . 0 1 8}$ & $\mathbf{5 0 . 9}$ & $\mathbf{1 . 1 3 E - 5 4}$ \\
\hline
\end{tabular}

\section{Correlation matrix of coefficients:}

$\begin{array}{lcc} & \text { Intercept } & \log _{10}(\text { Turb }) \\ \text { Intercept } & 1 & \\ \left.\log _{10} \text { (Turb }\right) & -0.9588 & 1\end{array}$

Some of the regression statistics are useful in evaluating this regression model. For example, the RMSE (even though it is expressed in log units), the MSPE, and the 90-percent prediction interval indicate the range in uncertainty associated with each regression-computed $S S C$ value. $R^{2}{ }_{a}$ indicates that the regression model explains 97 percent of the variability in sampled SSC. The PRESS is only relevant for comparisons to other regression models with the same response variable units. The t-statistics for the $y$ intercept and coefficient (slope) of $\log _{10}$ (turbidity) are larger than 2 , and the p-values are less than 0.05 , indicating that both are significant and should be included in the final model form. Helsel and Hirsch (2002, p. 239) discuss the option of omitting the $y$ intercept (thus forcing the $y$ intercept to equal zero). There are several tests the hydrographer can perform to help aid in the decision, but generally, omitting the $y$ intercept is discouraged. Hydrographers are encouraged to develop a regression model by forcing the $y$ intercept to equal zero as an iterative step in better understanding the data set and the effect of certain data points, specifically the smaller turbidity-SSC values.

Transformation of the response variable (SSC) has a consequence that must be considered when computing SSC: The regression estimates must be retransformed to the original units, a step that introduces a bias (usually negative) in computed SSC values (Miller, 1951; Koch and Smillie, 1986) unless the data are perfectly and positively correlated [as the $R_{a}^{2}$ approaches 1.0, the bias correction factor (BCF) also approaches 1.0]. The bias arises because regression estimates are the mean of $y$ given $x$ in log units, and retransformation of these estimates is not equal to the mean of $y$ given $x$ in linear space. To correct for this retransformation bias, Duan (1983) introduced a nonparametric BCF called the "smearing" estimator (Helsel and Hirsch, 2002, p. 256). The equation to compute the smearing $\mathrm{BCF}$ for base-10 logarithmic transformation is:

$$
B C F=\frac{\sum_{i=1}^{n} 10^{e_{i}}}{n} .
$$

where

$n \quad$ is the number of samples, and 


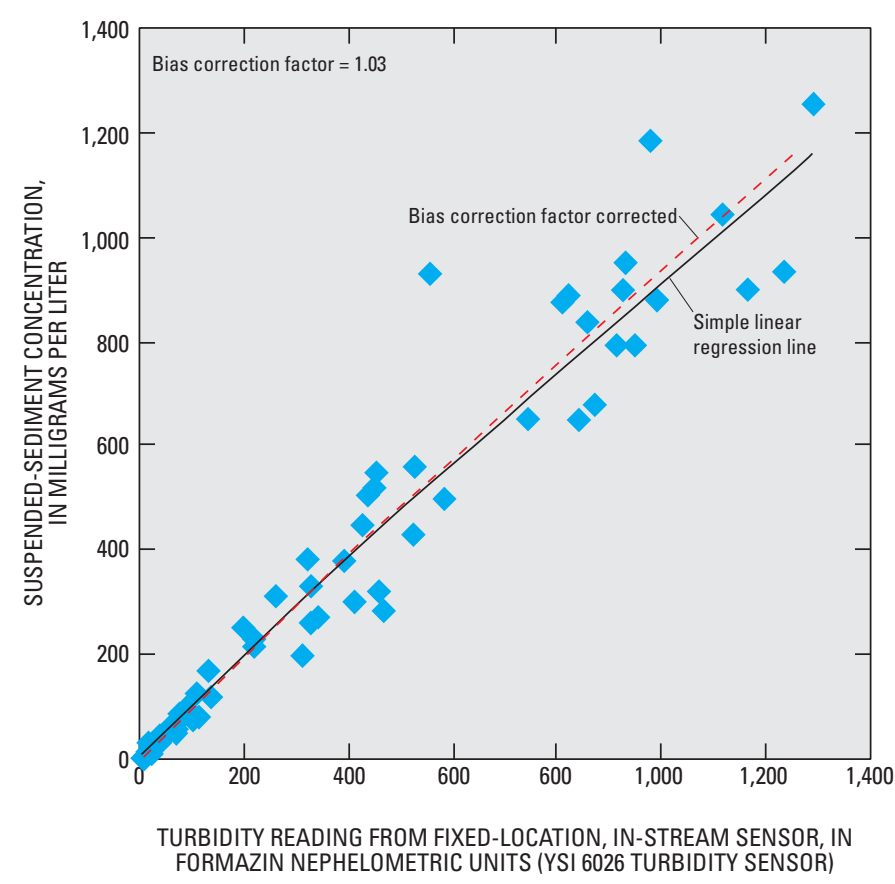

Figure 12. Comparison of turbidity and suspended-sediment concentration model-calibration data and uncorrected and bias-corrected simple linear regression lines for U.S. Geological Survey streamgage on Little Arkansas River near Sedgwick, Kansas, 1999-2005.

$e_{i} \quad$ is the residual or the difference between each measured and estimated concentration, in $\log$ units.

Regression-computed SSC values for Little Arkansas River near Sedgwick, Kansas, are corrected for bias by multiplying the retransformed $S S C$ value by the BCF.

Model-calibration data plotted concomitant with the biascorrected model line may not always result in what appears to be the best fit of the data. For BCFs larger than 1.0, model values will plot on the high side (more data points are below the curve than above it; fig. 12); that is, when the results of the simple linear-regression line are multiplied by the BCF and plotted, the curve is shifted upward from the original position. This same effect of BCFs with sediment-transport equations has been shown to fit data on the high side in other sedimenttransport studies (Bent, 2000). There also is an exact, minimum-variance unbiased estimator (MVUE; Cohn and others, 1989), but MVUE assumes a normal distribution of the residuals, which frequently is not the case.

A comparison of measured and model-estimated SSC indicates the accuracy of the regression model (fig. 13). The closer that points plot to the 1:1 line the more accurate the model predictions are.

Once the turbidity-SSC model is determined, the hydrographer needs to consider the potential benefits of adding streamflow as an explanatory variable. SLR analysis is preferred for sites where turbidity is the measure most strongly correlated with SSC or where MSPE is less than 20 percent.

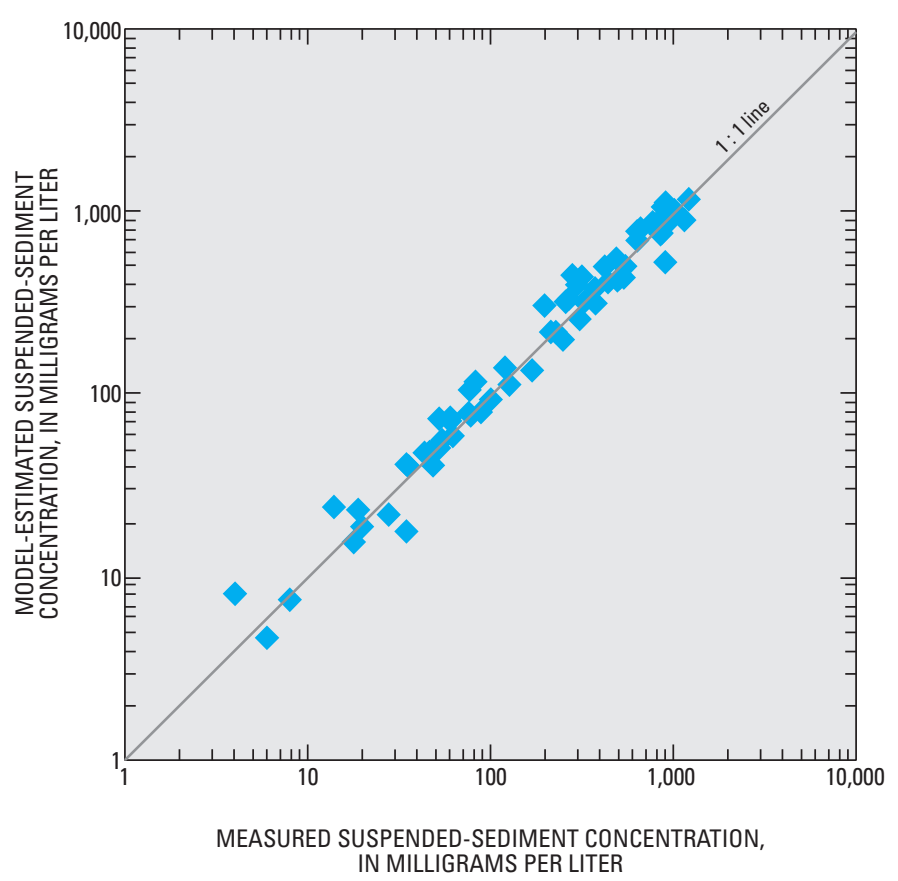

Figure 13. Comparison of measured and model-estimated suspended-sediment concentrations for U.S. Geological Survey streamgage on Little Arkansas River near Sedgwick, Kansas, 1999-2005.

Sites with a homogeneous source of suspended sediment and more than about 80 percent of the suspended material finer than $63 \mu \mathrm{m}$ are the best candidates for SSC computations using the SLR model. When turbidity is less correlated with SSC or when the MPSE is larger than 20 percent or sand (particle size coarser than $63 \mu \mathrm{m}$ ) constitutes an increasing percentage of the sediment in suspension as SSC increases, streamflow in addition to turbidity may better describe the variability in SSC. MLR model building is similar to SLR but should not precede SLR model development. Methods for building MLR models are discussed in a later section of this report titled "Multiple Linear Regression."

\section{Prediction Intervals}

Prediction intervals can be used to evaluate the uncertainty of SSC regression-computed values (Helsel and Hirsch, 2002). Prediction intervals define a range of values for the regression estimate associated with a known level of certainty. For a given turbidity value (explanatory variable), the 90-percent prediction interval represents a range of values within which there is a 90 -percent certainty that the true $S S C$ value occurs. The larger the 90-percent prediction interval, the more uncertainty there is associated with computed $S S C$. The prediction interval for a single response $y_{i}$ is approximately:

$$
E\left(y_{i}\right) \pm t \times s
$$


where

$E\left(y_{i}\right) \quad$ is the regression-estimated value, at $x_{\mathrm{i}} ;$ $t \quad$ is the value of the student's $t$ distribution having $n$ - 2 degrees of freedom ( $n$ is the number of observations) with the exceedance probability of $\alpha / 2$ (alpha value obtained from $t$ tables in the appendix of most statistics textbooks) for 90-percent prediction interval $\alpha=0.10$; and $s \quad$ is the standard error of regression or the RMSE.

\section{Multiple Linear Regression}

As previously stated, MLR represents an alternate tool for computing SSCs when the SLR MSPE is larger than 20 percent. However, MLR should only be considered for use when the p-value (probability value) of the partial F statistic (Helsel and Hirsch, 2002, p. 298) for streamflow is less than 0.025 . Comparison plots of the residuals from the turbiditySSC SLR to streamflow can indicate when an MLR model may decrease the amount of variability explained. The residual

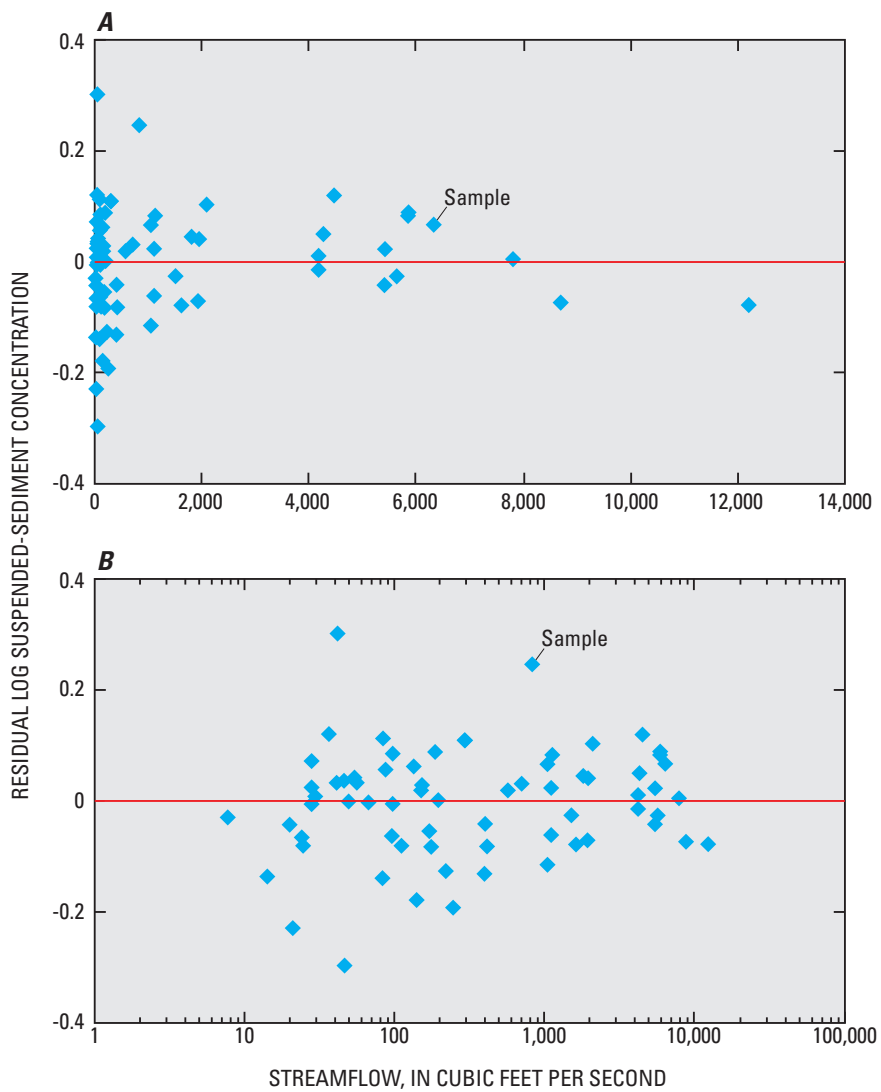

Figure 14. Comparison of streamflow in $A$, linear space and in $B, \log _{10}$ space to residuals from a simple linear regression analysis of turbidity and suspended-sediment concentrations for U.S. Geological Survey streamgage on Little Arkansas River near Sedgwick, Kansas, 1999-2005. plots for the Little Arkansas River near Sedgwick, Kansas, indicate that there is little or no change in variability with streamflow (fig. 14A and $B$ ). Neither of these plots supports the addition of streamflow to the $S S C$ model.

Other methods for evaluating which explanatory variables to include in the regression model are part of MLR model-building method described in Helsel and Hirsch (2002, p. 312-315). The possible explanatory variables in this case include turbidity and streamflow. Turbidity and streamflow are typically $\log _{10}$ transformed for a better regression model, but any combination of transformed or untransformed explanatory variables can be evaluated.

The MSPE for the SLR model of the Little Arkansas River near Sedgwick, Kansas, is larger than 20 percent, indicating that a MLR model with streamflow and turbidity should be considered. The streamflow variable is deemed significant in the regression model if the $p$-value of the partial F statistic is less than a predetermined alpha value $(\alpha)$ of 0.025 . As shown in table 4 , the p-value is larger than 0.025 for streamflow in the MLR model for the Little Arkansas River near Sedgwick, Kansas, indicating that the SLR model-and not a MLR model-should be used for computing SSC. The $R^{2}{ }_{a}$ should never be the sole criterion used to assess the appropriateness of a regression model because a large $R^{2}$ can occur even though the linear fit is poor (see Helsel and Hirsch, 2002, p. 18 and 228, and Glysson, 1987, p. 39-43). The regression diagnostics are reported in the default regression model output from Microsoft Excel or the "Regression Subset Selection" option of the USGS library for S-Plus for Windows (Slack and others, 2003).

Comparison plots of measured and model-estimated SSC for the SLR and MLR models can indicate the regression model with the most accuracy (fig. $15 A$ and $B$ ). The closer the points plot to the 1:1 line, the more accurate the model predictions are. The variance of the MLR residuals should be evaluated and compared to the SLR residuals (fig. 15A and $B$ ). The measured/estimated SSC and residual plots are nearly identical for the SLR and MLR models, suggesting that the models produce similar results.

\section{Regression Model Summary}

The regression model selected to compute SSC timeseries values for the Little Arkansas River near Sedgwick, Kansas, is the turbidity-SSC SLR model. Comparisons with the MLR model indicate that the addition of the streamflow variable slightly improved the SSC prediction but not sufficiently so as to justify its inclusion. In general, the simplicity of a SLR model is preferred over a MLR model that imparts modest improvement in accuracy to the computational process. Currently (2009), ADAPS (U.S. Geological Survey, 2003) can compute SSC using a SLR model. The use of ADAPS for computing SSC is desired because of the documentation of the regression model and when it was used. Had the MLR model been chosen, SSC values would have to be 
Table 4. Expressions for determining use of simple linear regression (SLR) or multiple linear regression (MLR) models for U.S. Geological Survey streamgage on Little Arkansas River near Sedgwick, Kansas.

[ $n$, number of samples; $R_{\mathrm{a}}^{2}$, adjusted coefficient of determination; RMSE, root-mean-squared error in log units; MSPE, model standard percentage error; $\mathrm{n} / \mathrm{a}$, not applicable]

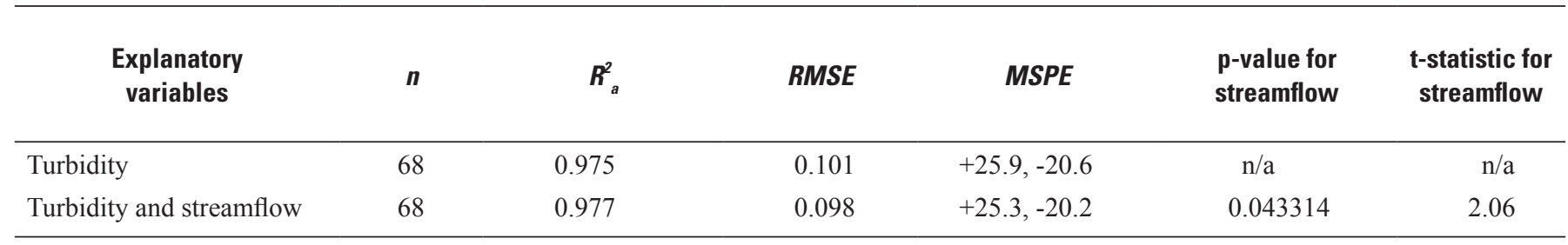

computed outside of ADAPS and then loaded to ADAPS (see Appendix 2).

A summary of regression information and expressions should be recorded in the station analysis for "Suspended Sediment" (example 1 of Appendix 1). The summary contains information specific to the development of the regression model. The hydrographer should summarize the reasoning for selection of the model, the final regression model and associated statistics, and the dates for which the model was used to compute SSC and SSL. A senior hydrographer should review the summary to determine its adequacy.

\section{Computation of Suspended-Sediment Concentration and Load Time-Series Record}

SSC time series should be computed at the same time step as the measured in-stream turbidity and streamflow time series by means of an appropriate regression model. Depending on the model form and which explanatory variables are used, the regression model can be implemented as a turbidity-SSC rating in NWIS to calculate a SSC time series. Details for developing a SSC time series within NWIS are presented in Appendix 2.

$\log _{10}$-transformed SLR models can be expressed as a power function and used to compute instantaneous values of SSC in ADAPS. The "equation rating" in ADAPS computes instantaneous values for the output data description (DD) and SSC on the basis of instantaneous values of the input DD (turbidity; U.S. Geological Survey, 2003). Retransformation of the $\log _{10}$-transformed SLR model (equation 6) is shown in equation 7.

The $\log _{10}$-transformed SLR model follows:

$$
\log _{10}(S S C)=b_{1} \log _{10}(\text { Turb })+b_{0},
$$

where
SSC is suspended-sediment concentration, in milligrams per liter;
$b_{1} \quad$ is the slope;
Turb is turbidity; and
$b_{0} \quad$ is the y intercept.

The $\log _{10}$-transformed SLR model (equation 6) can be retransformed and corrected for bias with a BCF resulting in equation 7 :

$$
S S C=10^{b_{0}} \text { Turb }^{b_{1}} \times B C F .
$$

For the Little Arkansas River near Sedgwick, Kansas, the model, $\log _{10} S S C=0.943 \log _{10}$ Turb +0.130 , and $B C F, 1.03$, can be retransformed to $S S C=10^{0.130} \mathrm{Turb}^{0.943} \times 1.03$, or

$$
S S C=1.39 \text { Turb }^{0.943}
$$

The hydrographer also should consider and perhaps limit computed values extrapolated beyond the range of explanatory variable values (minima and maxima of the explanatory variables). The veracity of extrapolated model values must be evaluated. Typically, the number of extrapolated values can be minimized if: (1) the range of the model-calibration data set is maximized by collecting samples at both extremes, and (2) the make and model of the fixed-location turbidity sensor are identical to the manually deployed field-turbidity sensor with similar maximum recording levels. Computed values that are substantially beyond the range of the calibration data should be withheld from public display until those values can be verified by new SSC data. If a replacement or supplemented sensor has a maximum recording level that is more than 10 percent larger than the maximum value of the calibration data set, the computed SSC values greater than the calibration data set maximum should be withheld from display until those values can be verified with samples collected in the range between the new sensor maximum recording level and the upper limit of the regression model.

\section{Estimates for Periods of Missing Data}

USGS policy (2009) precludes storage of estimated instantaneous values of turbidity in the NWIS database (Office of Water Quality Technical Memorandum 2005.03; U.S. Geological Survey, 2005). However, data collected from sources other than the fixed-location turbidity sensor can be used to supplement discrete periods of missing turbidity time-series record, which includes periods for which measured turbidity values are considered unreliable, such as from turbidity sensor 

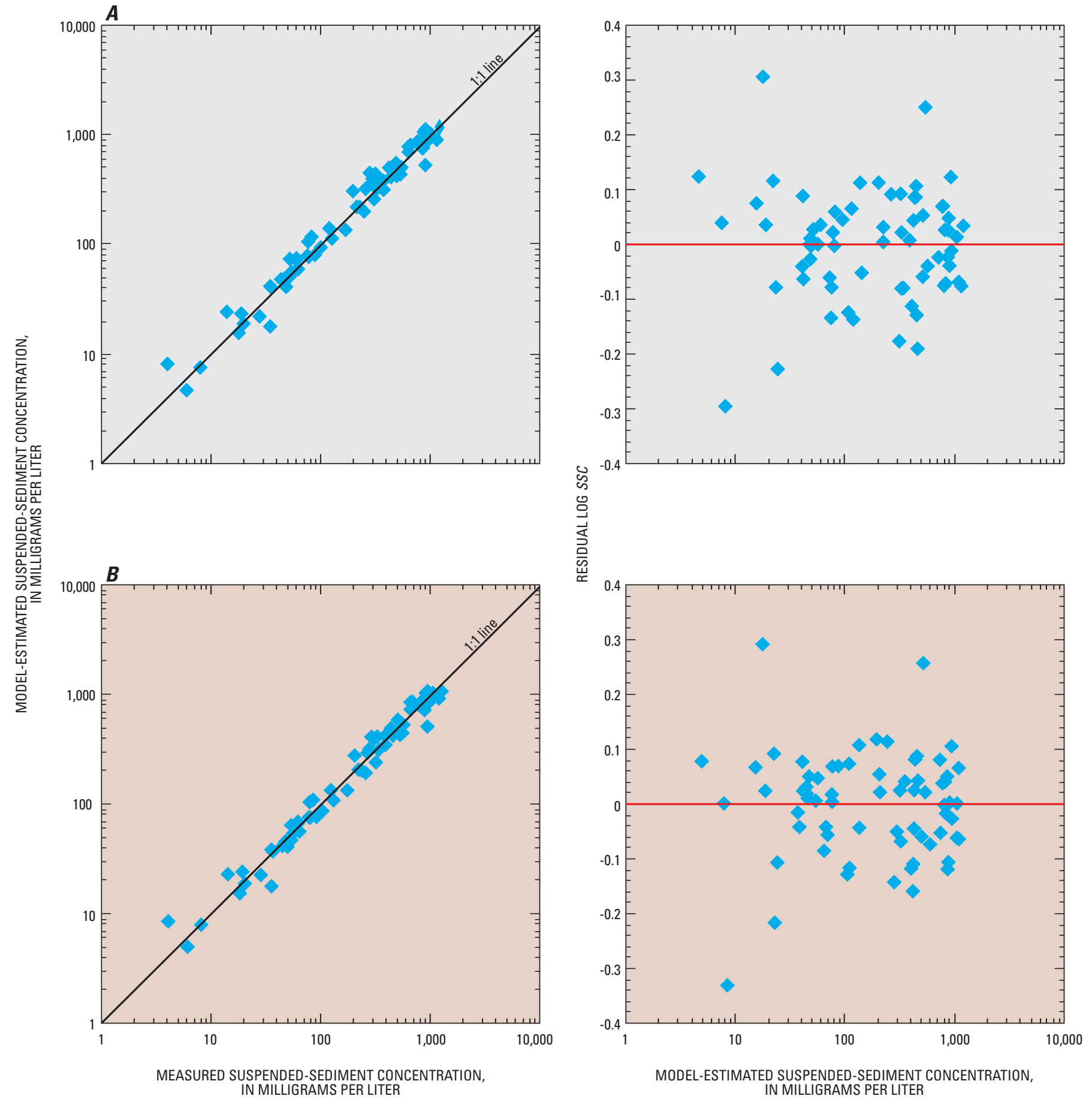

Figure 15. Comparison of measured and estimated suspended-sediment concentrations and residuals in log space from $A$, simple and $B$, multiple linear regression models for U.S. Geological Survey streamgage on Little Arkansas River near Sedgwick, Kansas. 
truncation at large $S S C$ values. For example, onsite measurements made using a cleaned and calibrated field sensor while the fixed-location sensor is being cleaned and calibrated can be used to fill in a part of the missing turbidity time-series record during the site visit.

The appropriateness of estimating mean daily turbidity values is governed by a number of factors, the most effectual of which are the duration of the missing record, availability of flow data for the missing-record period, and the availability of data describing historical relations among turbidity, streamflow, and SSC. Daily statistics for periods containing missing data should be calculated with an appropriate level of scrutiny and in accordance with Wagner and others (2006). Mean daily turbidity values should not be calculated solely for the purpose of calculating mean daily $S S C$ values. Daily $S S C$ values should be estimated by methods described by Porterfield (1972) or Koltun and others (2006). The hydrographer should note in the station analysis that the uncertainties associated with $S S C$ estimates derived from estimated turbidity data are unknown. Rasmussen and Ziegler (2003), Bragg and others (2007), and Lee and others (2009) demonstrate different techniques for estimating missing or truncated instantaneous values of turbidity and $S S C$.

Estimation of missing or truncated instantaneous SSC values (without estimating turbidity values) in some instances can be performed outside of ADAPS to meet study objectives. The method(s) used in those instances to develop estimates should be well documented and peer reviewed.

\section{Computation of Suspended-Sediment Load Time-Series Record}

A time series of SSL is calculated from SSC and streamflow for the same site. Instantaneous $S S L$ is calculated using the following equation:

$$
S S L_{i}=S S C_{i} \times Q_{i} \times c
$$

where

$$
\begin{array}{cl}
S S L_{i} & \text { is the computed suspended-sediment load, in } \\
& \text { tons per second, or pounds per second; } \\
S S C_{i} & \text { is the computed suspended-sediment } \\
& \text { concentration for the ith value, in } \\
& \text { milligrams per liter; } \\
Q_{i} \quad \text { is the streamflow for the ith value, in cubic } \\
\text { feet per second; and } \\
\text { c is a constant, } 3.121 \times 10^{-8} \text {, for converting the } \\
\text { units to tons per second, or } 6.242 \times 10^{-5} \text { for } \\
\text { pounds per second. }
\end{array}
$$

The instantaneous $S S C$ and streamflow values also can be used to compute daily, monthly, or annual SSLs using the following equation:

$$
S S L_{n}=\sum_{i=1}^{n} \frac{\left(C_{1}+C_{i-1}\right) \times\left(Q_{i}+Q_{i-1}\right) \times\left(t_{i}-t_{i-1}\right)}{4} \times c,
$$

where

$$
\begin{aligned}
& S S L_{n} \quad \text { is the computed suspended-sediment load for } \\
& \text { the desired time period, in tons; } \\
& C_{i} \quad \text { is the suspended-sediment concentration for } \\
& \text { the ith time, in milligrams per liter; } \\
& C_{i-1} \quad \text { is the suspended-sediment concentration for } \\
& \text { the ith minus } 1 \text { time, in milligrams per } \\
& \text { liter; } \\
& Q_{i} \quad \text { is the streamflow for the ith value after } \\
& \text { midnight, in cubic feet per second; } \\
& Q_{i-1} \quad \text { is the streamflow for the ith minus } 1 \text { value } \\
& \text { after midnight, in cubic feet per second; } \\
& t_{i} \quad \text { is the time for the ith value after midnight; } \\
& t_{i-1} \quad \text { is the time for the (ith-1) value after midnight; } \\
& c \text { is a constant, } 0.0027 \text {, for converting the units } \\
& \text { to tons per day; and } \\
& n \quad \text { is the number of instantaneous values within } \\
& \text { the desired period (day, month, year). }
\end{aligned}
$$

The hydrographer should identify any periods of missing record and determine how to provide the best estimate of SSL for periods when computed SSC data, streamflow data, or both are missing. The options to estimate SSL include: (1) interpolate the missing values between known values, taking into consideration other available data, (2) estimate $S S L$ on the basis of some other data, such as streamflow (a sedimenttransport curve for the site) or SSL derived from a streamgage with similar sediment characteristics using appropriate scaling factors, or (3) another technically supportable method. Regardless of the method or combination of methods used to estimate missing $S S L$ data, the rationale should be fully explained in the station analysis or associated report.

Uncertainty estimates of long-term suspended-sediment load computed by summing retransformed SSC from SLR or MLR models with transformed response variables can be computed. Estimates of the mean squares errors are discussed in Gilroy and others (1990).

\section{Model Validation and Maintenance of a Long- Term Suspended-Sediment Concentration Record}

Once an acceptable regression model is developed, it can be used to compute SSC beyond the period of record used in model development with proper sample collection and analysis. Maintenance of a long-term SSC record requires ongoing collection of turbidity and streamflow time-series data and sample collection for reanalysis and verification of the current SSC regression model. The method for validating the regression model is affected by the frequency of calibration-sample collection and the purpose of the study. Regression models can be validated annually (or at some other frequency as needed on the basis of the nature of the monitored hydrologic system and its watershed, and the needs and constraints of the monitoring program) after sufficient applicable new data have been collected or on the basis of other valid criteria. A fundamental 
characteristic of hydrology is variability, with periods of floods and periods of droughts. Additionally, watershed conditions can change seasonally or from other factors such as through changes in land use, implementation of best management practices, or by wildfire. Therefore, regression models to compute $S S C$ at a site should never be considered static but rather considered to represent a set period in a continually dynamic system in which additional data will help verify any change in $S S L$, type, and source.

\section{Validation of Suspended-Sediment Concentration Model}

One approach to updating the regression model is to plot new observations with the original model-calibration data set and recompute the regression coefficient(s) and $y$-intercept. Typically, at least 4 to 10 SSC samples and associated turbidity and streamflow values representing a wide range of streamflows are collected annually, depending on the site and monitoring program, to validate the existing regression model. More such data may be needed. The additional data plotted along with the model-calibration data set for comparison should indicate any significant change in the turbidity$S S C$ relation that would signal the need for a completely revised regression model or additional and more frequent sample collection. A review of the scatter plot for the Little Arkansas River near Sedgwick, Kansas, suggests that there

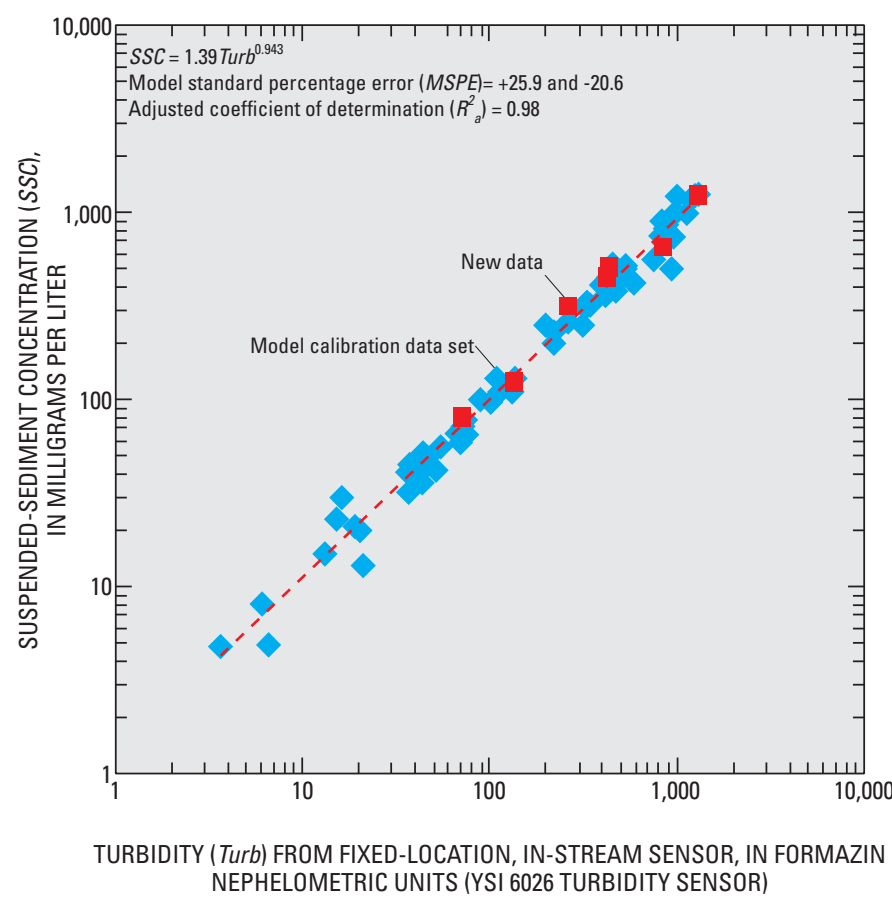

Figure 16. Model-calibration data set (water years 1999-2005) and new (water year 2006) turbidity and suspended-sediment concentration data for U.S. Geological Survey streamgage on Little Arkansas River near Sedgwick, Kansas. has been no significant change in the turbidity-SSC relation (fig. 16).

A regression model developed from new measurements not used in previous model development should be compared to the existing regression model. Analysis of covariance (ANCOVA; see Helsel and Hirsch, 2002, p. 316) can be used to test (1) the regression model on the basis of the original model data and additional data, (2) the original regression model, and (3) the regression model solely on the basis of the additional data. ANCOVA will determine if the slope or $y$ intercept of any of these models is significantly different, indicating a fundamental shift in the turbidity-SSC relation and the possible need to develop a new model. If a shift occurred, the hydrographer also will need to determine when it occurred and when to cease use of the existing model and begin use of a new model. A fundamental shift such as this should be accounted for by a major change in sediment source or transport processes in the watershed, such as those resulting from a substantial change in land use or land cover, construction or removal of an impoundment, wildfire, landslide, or a major flood. A more likely scenario is a gradual change over years that can be detected only by continued sample collection and analysis.

New data that do not significantly change the original regression should be added to the model-calibration data set to refine the regression model. The slope, $y$ intercept, and the computed SSC values from the new model will not be significantly different from the old model, but the improved estimate of RMSE may reduce the prediction interval. The hydrographer has to determine when the refined model will take effect. If sample collection and analysis are considered on an annual basis, the new model should start at the beginning of the ensuing water year. An approved computed SSC time series should not be recomputed unless there is strong evidence that the turbidity-SSC relation changed during the approved period. The hydrographer in this case has determined that the revised model (fig. 16) will take effect at the beginning of water year 2006 .

\section{Sampling Plan}

A sampling plan to obtain the requisite turbidity, streamflow, and SSC data should be devised to periodically validate and refine the existing regression model. Conditions or events that may cause variability in the turbidity-SSC relation also should be considered when devising a sampling plan for maintaining long-term SSC record. Sample values from the model-calibration data set may indicate periodic, seasonal, or other fluctuations that may induce variability in the current model. These fluctuations should be considered when collecting representative samples to facilitate adequate validation of an existing regression model. A prudent and affordable annual sampling plan for the Little Arkansas River near Sedgwick, Kansas, includes two to four spring stormwater runoff sample sets, two to four summer stormwater runoff or 
base streamflow sample sets, and one to two winter base-flow sample sets.

\section{Changes to Turbidity Sensor Model or Type}

Different sensors can provide different turbidity readings for the same environmental sample (Landers, 2003). Manufacturers have made improvements and design changes to turbidity sensors over time. A change of sensor model or type most likely will require an adjustment to the historical values so that the equivalency of turbidity-sensor-response characteristics of historical and newly collected data is maximized. The hydrographer should compare turbidity measurements between differing sensors in a range of environmental samples. The difference between sensors cannot be identified in formazin standards (Hach; Loveland, Colo.) and may be reversed in polystyrene bead standards (APS Analytical Standards Inc.; Redwood City, Calif.; fig. 17).

Typically, turbidity data collected with an old sensor can be adjusted to an approximately equivalent reading for a new sensor by means of a conversion factor. The conversion factor is computed from a data set consisting of concurrent turbidity measurements collected by the old and new sensors arrayed adjacent to each other in the stream. Care should be taken to ensure that the range of the concurrent measurements spans the known range of turbidity values at the site. One way of achieving this is to operate both sensors in-stream, side-byside, over a wide range of turbidity conditions. The resulting data set will provide a robust conversion factor for the monitoring site.

The site-specific turbidity conversion factor can be calculated several ways, such as from the mean or median of the instantaneous conversion factors or by means of an ordinary least squares (OLS) regression (if the relation is linear; fig. 18). The median conversion factor computed as the ratio, new sensor value/old sensor value, is the least likely to

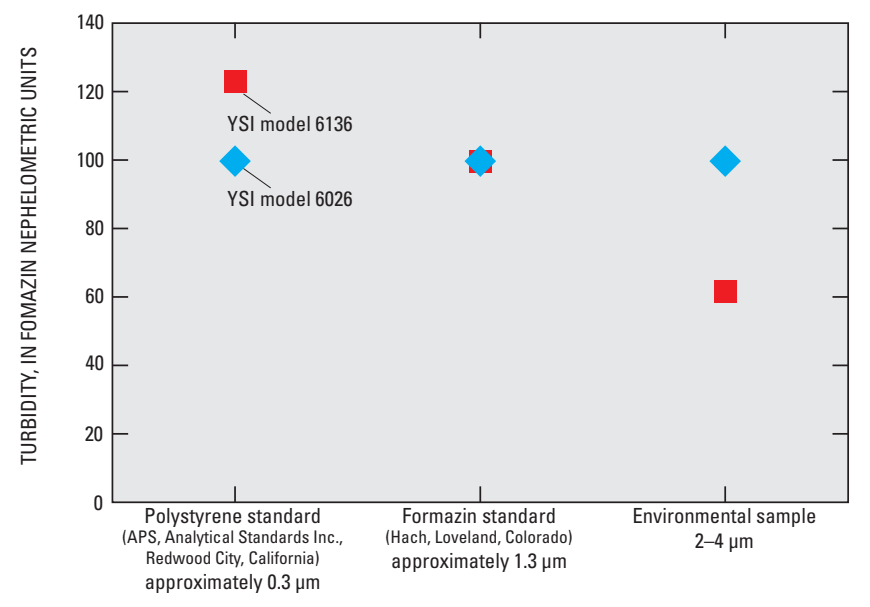

Figure 17. Comparison of turbidity measurements from YSI turbidity models 6026 and 6136 (YSI Incorporated, Yellow Springs, Ohio) in various solutions.

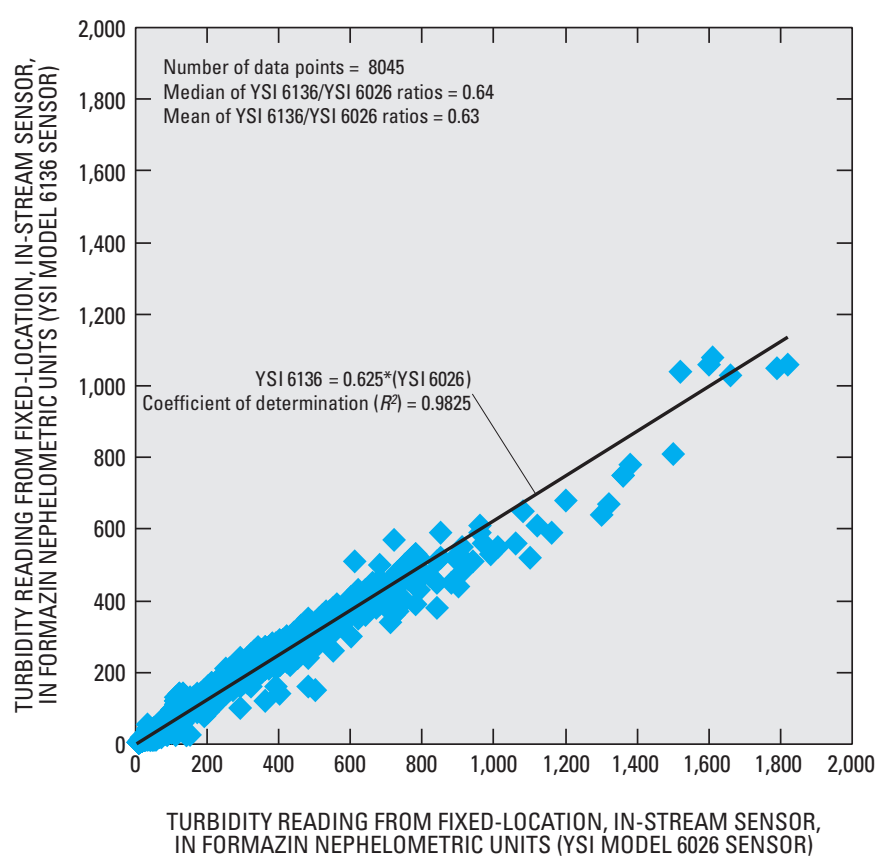

Figure 18. Relation between YSI 6026 and YSI 6136 turbidity sensor values, U.S. Geological Survey streamgage on Little Arkansas River near Sedgwick, Kansas, July 14, 2004, to August 26, 2005.

be affected by outliers and was selected for use. YSI Incorporated (2003) suggests a conversion factor of 0.65 for converting turbidity measurements made with sensor model 6026 to comparable measurements made with sensor model 6136. The conversion factor for the Little Arkansas River near Sedgwick, Kansas, was 0.64 , which was obtained by taking the median of the instantaneous conversion factors from several months of concurrent in-stream turbidity measurements with both sensors (fig. 18).

The model-calibration data set can be adjusted using the conversion factor, and new regression model coefficients can be computed for the historical turbidity data. Each historical turbidity value in the model-calibration data set is multiplied by an empirically derived (or, lacking that, manufacturerspecified) conversion factor. Thus, the converted historical data are normalized with respect to the non-model data so that either sensor would provide the same value under identical environmental conditions. The adjusted model-calibration data then are used to recompute the regression model for computing SSC following the same steps used to develop the original model. The revised regression model then can be used to compute $S S C$ on the basis of measurements from the new turbidity sensor. Historical SSC and turbidity time-series data with the ADAPS aging status of "approved" should not be recalculated or deleted. The hydrographer should plot the time series of historical $S S C$ values that overlap with the time series from the new SSC regression model to ensure that the new and old equations are comparable. 


\section{Factors Affecting Relation Between Turbidity and Suspended-Sediment Concentration}

The hydrographer should be mindful of factors other than SSC that can affect turbidity measurements. Particle size, shape, and color all affect the amount of light scattered, the important parameter for turbidity (Sutherland and others, 2000). Light is absorbed and scattered as it travels from a light source, to suspended particles, and is reflected back to a detector. When particle sizes larger than about $90 \mu \mathrm{m}$ (very fine sand) are in suspension, the turbidity- $S S C$ relation will be negatively biased, and that bias will increase as particle size increases (Anderson, 2005). Particle shape affects the scatter intensity. Darker or more black-colored (Munsell Color Co., 2000) particles also have been shown to substantially affect turbidity measurements by imparting a negative bias in measurements (Sutherland and others, 2000). Insights as to the potential effects of these and other factors might be gained from having particle-size and color analyses performed on selected water-sediment samples. Other factors affecting the turbidity-SSC relation are measurement error (including $S S C$ sample collection and analysis) and natural variability caused by processes not evaluated in the regression model. Turbidity resulting from the presence of suspended microorganismsprincipally phytoplankton-can result in increased uncertainty in the $S S C$ determination. Hence, caution should be used when inferring SSC from turbidity or turbidity and streamflow values in water with substantial microbiological activity.

\section{Summary}

Collection, computation, and publication of suspendedsediment and related environmental data are a necessary part of investigations to evaluate effects of fluvial sediment and sediment-associated constituents on water resources. In-stream continuous turbidity data, or continuous turbidity and streamflow data, calibrated with measured suspended-sediment concentration (SSC) data, can be used to compute a time series of SSC and suspended-sediment load (SSL). Development of a simple linear regression model between turbidity and measured SSC data is the first step in computing a SSC time series. If the model standard percentage error (MSPE) simple linear regression model meets an established minimum criterion, this model can be used to compute a time series of SSC. If the simple regression model does not meet the acceptability criterion, a multiple linear regression model using paired instantaneous turbidity and streamflow data is developed. If the addition of streamflow is statistically significant and the uncertainty associated with the multiple regression model results in an improvement over that for the simple linear model and is ultimately acceptable, it is used as the basis for computing a time series of SSC. The computed SSC time series is subsequently used with its paired streamflow time series to compute a time series of SSL by standard U.S. Geological Survey techniques. Time-series SSC and SSL data can be used to better describe variability in suspended-sediment conditions, to evaluate $S S C$ relative to numerical water-quality criteria and management goals, and to make watershed comparisons.

Once an acceptable regression model is developed, it can be used to compute $S S C$ beyond the period of record used in model development with proper sample collection and analysis. Maintenance of a long-term SSC record requires ongoing collection of turbidity and streamflow time-series data and calibration-sample collection for reanalysis and verification of the current SSC regression model. The method for validating the regression model is affected by the frequency of sample collection and the purpose of the study. Regression models can be validated annually (or at some other frequency as needed on the basis of the nature of the monitored hydrologic system and its watershed, and the needs and constraints of the monitoring program) after sufficient new data have been collected or on the basis of other valid criteria. Regression models to compute $S S C$ are generally site specific and should never be considered static but rather considered to represent a set period in a continually dynamic system in which additional data will help verify any change in $S S L$, type, and source.

\section{Acknowledgments}

This report was prepared by the USGS Kansas Water Science Center (WSC), Lawrence, Kansas, and the Offices of Surface Water and Water Quality, Reston, Virginia. USGS personnel in the California, Kansas, Oregon, and Pennsylvania WSCs provided astute technical advice and assistance. Information, discussion, comments, and suggestions from Teresa J. Rasmussen (Kansas WSC) and USGS colleague reviewers Paul A. Buchanan (California WSC), Elizabeth A. Hittle (Pennsylvania WSC), Gregory F. Koltun (Ohio WSC), David K. Mueller (Central Region), and Mark A. Uhrich (Oregon WSC) resulted in substantial improvements to this document. Trudy Bennett was responsible for oversight and data collection at the Little Arkansas River near Sedgwick, KS site.

\section{Selected References}

American Public Health Association, American Water Works Association, and Water Pollution Control Federation, 2005, Standard methods for the examination of water and wastewater (21st ed.): Washington, D.C., American Public Health Association, 1,368 p.

ASTM International, 2007, D4410, in terminology for fluvial sediment, annual book of standards, water and environmental technology: West Conshohocken, Pennsylvania, ASTM International, $7 \mathrm{p}$. 
Anderson, C.W., 2005, Turbidity: U.S. Geological Survey Techniques of Water-Resources Investigations, book 9, chaps. A6.7, available on Web, accessed March 2008, at http://pubs.water.usgs.gov/twri9A

Angino, E.E., and O'Brien, W.J., 1968, Effects of suspended material on water quality, in Proceedings of Symposium on Geochemistry, Precipitation, Evaporation, Soil Moisture, Hydrometry, General Assembly of Bern, September-October 1967: International Association of Science Hydrology, no. 78 , p. $120-128$.

Bent, G.C., 2000, Suspended-sediment characteristics in the Housatonic River Basin, western Massachusetts and parts of eastern New York and northwestern Connecticut, 1994-96: U.S. Geological Survey Water-Resources Investigations Report 00-4059, 121 p.

Bragg, H.M., Sobieszczyk, Steven., Uhrich, M.A., and Piatt, D.R., 2007, Suspended-sediment loads and yields in the North Santiam River Basin, Oregon, water years 1999-2004: U.S. Geological Survey Scientific Investigations Report 2007-5187, 26 p., available on Web, accessed March 2008, at http://pubs.usgs.gov/sir/2007/51877.

Buchanan, P.A., and Ganju, N.K., 2004, Summary of suspended-sediment concentration data, San Francisco Bay, California, water year 2002: U.S. Geological Survey OpenFile Report 2004-1219, 45 p., available on Web, accessed March 2008, at http://pubs.usgs.gov/of/2004/1219].

Buchanan, P.A., and Schoellhamer, D.H., 1995, Summary of suspended-solids concentration data, Central and South San Francisco Bays, California, water years 1992 and 1993: U.S. Geological Survey Open-File Report 94-543, 15 p.

Christensen, V.G., Jian, Xiaodong, and Ziegler, A.C., 2000, Regression analysis and real-time water-quality monitoring to estimate constituent concentrations, loads, and yields in the Little Arkansas River, south-central Kansas, 1995-99: U.S. Geological Survey Water-Resources Investigations Report 00-4126, 36 p.

Clesceri, L.S., Greenberg, A.E., and Eaton, A.D., eds., 1998, Standard methods for the examination of water and wastewater (20th ed.): American Waterworks Association and Water Environment Federation, 1,200 p.

Cohn, T.A., DeLong, L.L., Gilroy, E.J., Hirsch, R.M., and Wells, D.K., 1989, Estimating constituent loads: Water Resources Research, v. 25, no. 5, p. 937-942.

Cunnane, C., 1978, Unbiased plotting positions-A review: Journal of Hydrology, v. 37, p. 205-222.

Curtis, J.A., Flint, L.E., Alpers, C.N., Wright, S.A., and Snyder, N.P., 2006, Use of sediment rating curves and optical backscatter data to characterize sediment transport in the upper Yuba River watershed, California, 2001-03: U.S. Geological Survey Scientific Investigations Report 2005$5246,74 \mathrm{p}$.
Davies-Colley, R.J., and Smith, D.G., 2001, Turbidity, suspended sediment, and water clarity-A review: Journal of American Water Resources Association, v. 37, no. 55, p. $1,085-1,101$.

Davis, B.E., 2005, A guide to the proper selection and use of Federally approved sediment and water-quality samplers: U.S. Geological Survey Open-File Report 2005-1087, $20 \mathrm{p}$.

Downing, J.P., 1983, An optical instrument for monitoring suspended particulates in ocean and laboratory: in OCEANS 1983, San Francisco, August 29-September 1, 1983, p. 199-202.

Downing, J.P., Sternberg, R.W., and Lister, C.R.B., 1981, New instrumentation for the investigation of sediment suspension processes in the shallow marine environment: Marine Geology, v. 42, p. 19-34.

Downing, John, 2005, Turbidity monitoring, chapt. 24, in Down, R.D., and Lehr, J.H., eds., Environmental instrumentation and analysis handbook: Hoboken, New Jersey, John Wiley and Sons, Inc., p. 511-546.

Downing, John, 2006, Twenty-five years with OBS sensors-The good, the bad, and the ugly: Continental Shelf Research, $20 \mathrm{p}$.

Duan, Naihua, 1983, Smearing estimate-A nonparametric retransformation method: Journal of the American Statistical Association, v. 78, no. 383, p. 605-610.

Edwards, T.K., and Glysson, G.D., 1999, Field methods for measurement of fluvial sediment: U.S. Geological Survey Techniques of Water-Resources Investigations, book 3, chap. C2, 89 p.

Federal Interagency Sedimentation Project, 2008, Home page available on Web, accessed January 21, 2009, at http://fisp.wes.army.mill.

Gartner, J.W., and Gray, J.R., in press, Laser diffraction, in Gray, J.R., and Gartner, J.W., eds, Surrogate technologies for monitoring suspended-sediment and bed-load transport in rivers, in Charlesworth and Poleto, eds., Sedimentology in aqueous systems: London Wiley-Blackwell, Chapter 2.

Gilroy, E.J., Hirsch, R.M., and Cohn, T.A., 1990, Mean square error of regression-based constituent transport estimates: Water Resources Research, v. 26, no. 9, p. 2,069-2,077.

Gilvear, D.J., and Petts, G.E., 1985, Turbidity and suspended solids variations downstream of a regulating reservoir: Earth Surface Processes Landforms, v. 10, no. 4, p. 363373.

Glysson, G.D., 1987, Sediment transport curves: U.S. Geological Survey Open-File Report 87-218, 53 p. 
Glysson, G.D., 1989a, 100 Years of sedimentation study by the USGS, in Wang, Sam S.Y., ed., Proceedings of the International Symposium, Sediment Transport Modeling, August 14-18, 1989, New Orleans: New Orleans American Society of Civil Engineers, p. 260-265.

Glysson, G.D., 1989b, Criteria for a sediment dataset, in Proceedings of the International Symposium on Sediment Transport Modeling, August 14-18, 1989, New Orleans: New Orleans American Society of Civil Engineers, 7 p.

Glysson, G.D., Gray, J.R., and Conge, L.M., 2000, Adjustment of total suspended solids data for use in sediment studies, in Proceedings of the ASCE's 2000 Joint Conference on Water Resources Engineering and Water Resources Planning and Management, July 30-August 2, 2000, Minneapolis, Minnesota: Minneapolis, Minneapolis American Society of Civil Engineers, 10 p.

Glysson, G.D., Gray, J.R., and Schwarz, G.E., 2001, Comparison of load estimates using total suspended solids and suspended-sediment concentration data, in Proceedings of the ASCE World Water and Environmental Resources Congress, May 20-24, 2001, Orlando, Florida: American Society of Civil Engineers, 9 p.

Gooding, D.J., in press, Digital-optic imaging, in Gray, J.R., and Gartner, J.W., eds, Surrogate technologies for monitoring suspended-sediment and bed-load transport in rivers, in Charlesworth and Poleto, eds., Sedimentology in aqueous systems: London Wiley-Blackwell, Chapter 2.

Granato, G.E., 2006, Kendall-Theil Robust Line (KTRLinever. 1.0) - A visual basic program for calculating and graphing robust nonparametric estimates of linear-regression coefficients between two continuous variables: U.S. Geological Survey Techniques and Methods, book 4, chap. A7, $31 \mathrm{p}$.

Gray, J.R., and Gartner, J.W., 2006, Overview of selected surrogate technologies for continuous suspended-sediment monitoring, in Proceedings of the 8th Federal Interagency Sedimentation Conference, April 2-6, 2006, Reno, Nevada, p. 337-344, available on Web, accessed March 2008, at http://pubs.usgs.gov/misc reports/FISC 1947-2006/pdf/1st7thFISCs-CD/8thFISC/Session\%204C-1_Gray.pd),

Gray, J.R., and Gartner, J.W., 2009, Technological advances in suspended-sediment surrogate monitoring: Invited paper, Water Resources Research, v. 45, W00D29, doi:10.1029/2008WR007063, 20 p.

Gray, J.R., Glysson, G.D., and Edwards, T.E., 2008, Suspended-sediment samplers and sampling methods, in Garcia, Marcelo, ed., Sedimentation engineering-Processes, measurements, modeling, and practice: American Society of Civil Engineers Manual 110, chap. 5.3, p. 320-339.
Gray, J.R., Glysson, G.D., Turcios, L.M., and Schwarz, G.E., 2000, Comparability of total suspended solids and suspended-sediment concentration data: U.S. Geological Survey Water-Resources Investigations Report 00-4191, 14 p., available on Web, accessed March 2008, at http://water.usgs.gov/osw/pubs/WRIR00-4191.pds)

Gray, J.R., Gooding D.J., Melis, T.S., Topping, D.J., and Rasmussen, P.P., 2003, U.S. Geological Survey suspendedsediment surrogate research, part II-Optic technologies: Proceedings of the Virginia Water Research Symposium 2003, Water Resource Management for the Commonwealth, Virginia Polytechnic Institute and State University, Blacksburg, October 8-10, 2003, p. 58-64, available on Web, accessed March 2008, at http://water.usgs.gov/osw techniques/sediment/sedsurrogate2003workshop/gray melis.pd)

Gray, J.R., and Simões, F.J.M., 2008, Estimating sediment discharge, in Garcia, Marcelo, ed., Sedimentation engineering - processes, measurements, modeling, and practice: American Society of Civil Engineers Manual 110, Appendix D, p. 1,067-1,088.

Great Lakes Instruments, Inc., 1992, Turbidity measurement: Milwaukee, Wisconsin, Technical Bulletin Number T1 rev. $2-193,7$ p.

Hardison, C.H., 1969, Accuracy of streamflow characteristics, in Geological Survey Research, 1969: U.S. Geological Survey Professional Paper 650-D, p. D210-D214.

Helsel, D.R., and Hirsch, R.M., 2002, Statistical methods in water resources-hydrologic analysis and interpretation: U.S. Geological Survey Techniques of Water-Resources Investigations, book 4, chap. A3, 510 p., available on Web, accessed March 2008, at http://pubs.usgs.gov/twri/twri4a3/.

Horowitz, A.J., 2003, An evaluation of sediment rating curves for estimating suspended sediment concentrations for subsequent flux calculations: Hydrological Processes, v. 17, p. 3,387-3,409.

Insightful Corporation, 2001, S-PLUS 6 for Windows users guide: Seattle, Washington, Insightful Corporation, 688 p.

International Organization for Standardization, 1999, Waterquality determination of turbidity, method 7027: International Organization for Standardization, $10 \mathrm{p}$.

Kennedy, E.J., 1984, Discharge ratings at gaging stations: U.S. Geological Survey Techniques of Water-Resources Investigations, book 3, chap A10, 59 p.

Koch, R.W., and Smillie, G.M., 1986, Bias in hydrologic prediction using log-transformed regression models: American Water Resources Association, Water Resources Bulletin, v. 22, no. 5, p. 717-732. 
Koltun, G.F., Eberle, Michael, Gray, J.R., and Glysson, G.D., 2006, User's manual for the Graphical Constituent Loading Analysis System (GCLAS): U.S. Geological Survey Techniques and Methods, book 4, chap. C1, 51 p.

Koltun, G.F., Gray, J.R., and McElhone, T.J., 1994, User's manual for SEDCALC, a computer program for computation of suspended-sediment discharge: U.S. Geological Survey Open-File Report 94-459, 46 p.

Landers, M.N., 2003, Summary of blind sediment reference sample measurement session, in Gray J.R., and Glysson, G.D., eds, Proceedings of the Federal Interagency Workshop on Turbidity and Other Sediment Surrogates, April 30-May 2, 2002, Reno, Nevada: U.S. Geological Survey Circular 1250, p. 29-30.

Lee, C.J., Rasmussen, P.P., and Ziegler, A.C., 2008, Characterization of suspended-sediment loading to and from John Redmond Reservoir, east-central Kansas, 2007-08: U.S. Geological Survey Scientific Investigations Report 2008-5123, 25 p.

Lee, C.J., Rasmussen, P.P., Ziegler, A.C., and Fuller, C.C., 2008, Transport and sources of suspended sediment in the Mill Creek watershed, Johnson County, northeast Kansas, 2006-07: U.S. Geological Survey Scientific Investigations Report 2009-5001, 52 p.

Levesque, V.A., and Schoellhamer, D.H., 1995, Summary of sediment resuspension monitoring, Old Tampa Bay and Hillsborough Bay, Florida, 1988-91: U.S. Geological Survey Water-Resources Investigations Report 94-4081, $31 \mathrm{p}$.

Lewis, Jack, 1996, Turbiditycontrolled suspended sediment sampling for runoff event load estimation: Water Resources Research, v. 32, no. 7, p. 2,299-2,310.

Lietz, A.C., and Debiak, E.A., 2005, Development of rating curve estimators for suspended-sediment concentration and transport in the C-51 canal based on surrogate technology, Palm Beach County, Florida, 2004-05: U.S. Geological Survey Open-File Report 2005-1394, 19 p., available on Web, accessed March 2008, at http://pubs.usgs.gov/of/2005/13944.

Lipscomb, S.W., 1995, Quality assurance plan for discharge measurements using broadband acoustic doppler current profilers: U.S. Geological Survey Open-File Report 95-701, $12 \mathrm{p}$.

Miller, C.R., 1951, Analysis of flow-duration sediment rating curve method of computing sediment yield: U.S. Bureau of Reclamation, $55 \mathrm{p}$.

Munsell Color Co., 2000, Munsell soil color charts: Baltimore, Munsell Color Company, 22 p.
Nolan, K.M., Gray, J.R., and Glysson, G.D., 2005, Introduction to suspended-sediment sampling: U.S. Geological Survey Scientific Investigations Report 2005-5077, 1 CDROM, available on Web, accessed March 7, 2008, at http://pubs.usgs.gov/sir/2005/5077

Porterfield, George, 1972, Computation of fluvial-sediment discharge: U.S. Geological Survey Techniques of WaterResources Investigations, book 3, chap. C3, 66 p.

Pruitt, B.A., 2003, Uses of turbidity by States and Tribes, in Gray, J.R., and Glysson, G.D., eds., Proceedings of the Federal Interagency Workshop on Turbidity and Other Sediment Surrogates, April 30-May 2, 2002, Reno, Nevada: U.S. Geological Survey Circular 1250, p. 31-43, available on Web, accessed February 23, 2009, at http://pubs.usgs. gov/circ/2003/circ1250/pdf/circ1250.book_web.pd).

Putnam, J.E., and Pope, L.M., 2003, Trends in suspendedsediment concentration at selected stream sites in Kansas, 1970-2002: U.S. Geological Survey Water-Resources Investigations Report 03-4150, 36 p., available on Web, accessed March 2008, at http://ks.water.usgs.gov/Kansas pubs/reports/wrir.03-4150.htm

Rantz, S.E., and others, 1982, Measurement and computation of streamflow, volumes 1 and 2: U.S. Geological Survey Water-Supply Paper 2175, $631 \mathrm{p}$.

Rasmussen, P.P., Bennett, Trudy, Lee, C.J., and Christensen, V.G., 2002, Continuous in-situ measurement of turbidity in Kansas, in Proceedings of Turbidity and Other Surrogates Workshop, April 30-May 2, 2002, Reno, Nevada: Subcommittee on Sedimentation, available on Web, accessed March 2008, at http://water.usgs.gov/osw/techniques/TSS/rasmussen.pd

Rasmussen, P.P., and Ziegler, A.C., 2003, Comparison and continuous estimates of fecal coliform and Escherichia coli bacteria in selected Kansas streams, May 1999 through April 2002: U.S. Geological Survey Water-Resources Investigations Report 03-4056, 80 p., available on Web, accessed March 2008, at http://ks.water.usgs.gov/Kansas pubs/abstracts/wrir.abstract.03-4056.htm

Rasmussen, P.P., Gray, J.R., Ziegler, A.C., Glysson, G.D., and Anderson, Chauncy, in press, Turbidity (bulk optics), in Gray, J.R., and Gartner, J.W., eds, Surrogate technologies for monitoring suspended-sediment transport in rivers, in Charlesworth and Poleto, eds., Sedimentology in aqueous systems: London Wiley-Blackwell, Chapter 2.

Rasmussen, T.J., Ziegler, A.C., and Rasmussen P.P., 2005, Estimation of constituent concentrations, densities, loads, and yields on lower Kansas River, northeast Kansas, using regression models and continuous water-quality modeling, January 2000 through December 2003: U.S. Geological Survey Scientific Investigations Report 2005-5165, 117 p., available on Web, accessed March 2008, at http://pubs.usgs.gov/sir/2005/5165, 
Rasmussen, T.J., Lee, C.J., and Ziegler, A.C., 2008, Estimation of constituent concentrations, loads, and yields in streams of Johnson County, northeast Kansas, using continuous waterquality monitoring and regression models, October 2002 through December 2006: U.S. Geological Survey Scientific Investigatisons Report 2008-5014, 103 p., available on Web, accessed February 23, 2009, at http://pubs.usgs.gov/sir/2008/5014/.

Sadar, M.J., 1998, Turbidity science: HACH, Technical Information Series-Booklet No. 11, 26 p., available on Web, accessed March 2008, at http://www.hach.com fmmimghach?/CODE\%3AL7061549\%7C1.

Slack, J.R., Lorenz, D.L., and others, 2003, USGS library for S-PLUS for Windows-Release 2.1: U.S. Geological Survey Open-File Report 03-357, 3 p., available on Web only, accessed February 18, 2009, at http://water.usgs.gov/software/S-PLUSA.

Sutherland, T.F., Lane, P.M., Amos, C.L., and Downing, J., 2000, The calibration of optical backscatter sensors for suspended sediment of varying darkness levels: Marine Geology, v. 162, p. 587-597.

Uhrich, M.A., and Bragg, H.M., 2003, Monitoring in-stream turbidity to estimate continuous suspended-sediment loads and yields and clay-water volumes in the Upper North Santiam River Basin, Oregon, 1998-2000: U.S. Geological Survey Water-Resources Investigations Report 03-4098, 43 p.

U.S. Environmental Protection Agency, 1979, Methods for chemical analysis of water and wastes: Cincinnati, Ohio, U.S. Environmental Monitoring Laboratory, Office of Research and Development 600/4/79/020, p. 180.1-1 to 180.1-3.

U.S. Environmental Protection Agency, 1999, Guidance manual for compliance with the interim enhanced surface water treatment rule-Turbidity provisions: Washington, D.C., U.S. Environmental Protection Agency, Office of Water, EPA 815-R-99-010, variously paged.

U.S. Environmental Protection Agency, 2001, Water quality standards: Office of Water, available on Web, accessed March 7, 2008, at http://www.epa.gov/waterscience/standards/wqslibrary

U.S. Environmental Protection Agency, 2008, Total maximum daily loads, causes of impairment for 303(d) listed waters, available on Web, accessed January 14, 2009, at http://iaspub.epa.gov/waters10/attains_nation_ cy.control?p_report_type $=T \#$ causes_303d.

U.S. Geological Survey, variously dated, National field manual for the collection of water-quality data: U.S. Geological Survey Techniques of Water-Resources Investigations, book 9, chaps. A1-A9, available on Web, accessed February 18, 2009, at http://pubs.water.usgs.gov/twri9A.
U.S. Geological Survey, 2000, Collection and use of total suspended solids data-USGS policy on collection and use of total suspended solids data: Office of Surface Water, and Office of Water Quality Joint Technical Memorandum 2001.03 (http://water.usgs.gov/admin/memo/SW/sw01.03.htm).

U.S. Geological Survey, 2002, Policy and technical guidance on discharge measurements using an acoustic doppler current profiler: Office of Surface Water Technical Memorandum 2002.02, available on Web, accessed January 21, 2009, at http://water.usgs.gov/admin/memo/SW/OSW.2002.02.htm.

U.S. Geological Survey, 2003, User's manual for the National Water Information System of the U.S. Geological Surveyautomated data processing system (ADAPS), ver. 4.3: U.S. Geological Survey Open-File Report 03-123, 413 p., available on Web, accessed March 2008, at http://pubs.usgs.gov/of/2003/ofr03123,

U.S. Geological Survey, 2005, Use of the program HYDRA to estimate or modify unit values in ADAPS: Office of Water Quality Technical Memorandum 2005.03, available on Web, accessed February 19, 2009, at http://water.usgs.gov/admin/memo/QW/qw05.03.htm.

U.S. Geological Survey, 2006, User's manual for the National Water Information System of the U.S. Geological Survey, water-quality system (QWDATA), ver. 4.4: U.S. Geological Survey Open-File Report 2006-1145, 372 p., available on Web, accessed March 7, 2008, at http://pubs.usgs.gov/of/2006/1145,

Wagner, R.J., Boulger, R.W., Jr., Oblinger, C.J., and Smith, B.A., 2006, Guidelines and standard procedures for continuous water-quality monitors - station operation, record computation, and data reporting: U.S. Geological Survey Techniques and Methods 1-D3, 51 p., 8 attachments, available on Web, accessed March 7, 2008, at http://pubs.water.usgs.gov/tm1d3.

Walling, D.E., 1977, Assessing the accuracy of suspended sediment rating curves for a small basin: Water Resources Research, v. 13, p. 531-538.

YSI, Incorporated, 2003, 6136 Technical document, available on Web, accessed March 2008, at http://www.ysilifesciences. com/extranet/EPGKL.nsf/5992085488f9da9d85256a5 50047c2a2/f2c571cc22155adc85256b750076b4f5/\$F ILE/6136\%20Turbidity\%20Tech\%20Doccomp.pds

Ziegler, A.C., 2003a, Issues related to use of turbidity measurements as a surrogate for suspended sediment, in Gray, J.R., and Glysson, G.D., eds., Proceedings of the Federal Interagency Workshop on Turbidity and Other Sediment Surrogates, April 30-May 2, 2002, Reno, Nevada: U.S. Geological Survey Circular 1250, p. 16-18, on available on Web, accessed November 2008, at http://water.usgs.gov/osw/techniques/TSS/ZieglerT.pdf. 
Ziegler, A.C., 2003b, Breakout session 1-definition of optical methods for turbidity and data reporting, in Gray, J.R., and Glysson, G.D., eds., Proceedings of the Federal Interagency Workshop on Turbidity and Other Sediment Surrogates, April 30-May 2, 2002, Reno, Nevada: U.S. Geological Survey Circular 1250, p. 16-18, available on Web, accessed November 2008, at http://pubs.usgs.gov/circ/2003/circ12501 pdf/circ1250.book_web.pd). 


\section{Appendixes}




\section{Appendix 1. Examples of Suspended-Sediment Concentration Models from Kansas, Oregon, Florida, and California}

Turbidity and SSC data and models from rivers in four States are presented to illustrate turbidity-SSC applications at a variety of geographic locations, drainage areas, and freshwater/saltwater conditions. Examples are courtesy of Heather Bragg and Mark Uhrich of the Oregon WSC (2007), Paul Buchanan of the California WSC (2004), A.C. Lietz (retired), and Elizabeth Hittle of the Pennsylvania WSC (2005).

U.S. Geological streamgages used for examples of turbidity and suspended-sediment concentration (SSC) data and regression models.

\begin{tabular}{ccccccc}
\hline Example & $\begin{array}{c}\text { Station } \\
\text { number }\end{array}$ & Station name & \multicolumn{2}{c}{$\begin{array}{c}\text { Turbidity } \\
\text { instrument make } \\
\text { and model }\end{array}$} & $\begin{array}{c}\text { Fresh- or } \\
\text { saltwater }\end{array}$ & $\begin{array}{c}\text { Drainage area } \\
\text { (square miles) }\end{array}$ \\
\hline 1 & 07144100 & Little Arkansas River near Sedgwick, Kansas & YSI model 6026 & Freshwater & 1,239 \\
2 & 14178000 & North Santiam River below Boulder Creek, Oregon & YSI model 6026 & Freshwater & 216 \\
3 & 02279000 & C-51 Canal, Palm Beach County, Florida & YSI model 6026 & Freshwater & Not applicable \\
4 & 11458370 & Mare Island Causeway, San Pablo Bay, California & D and A OBS & Saltwater & Not applicable \\
\hline
\end{tabular}




\title{
Example 1. Complete Review Package for Little Arkansas River near Sedgwick, Kansas
}

\author{
WATER-QUALITY MONITOR STATION ANALYSIS \\ 2005 WATER YEAR \\ SUSPENDED-SEDIMENT RECORD \\ 07144100 \\ Little Arkansas River near Sedgwick, Kansas
}

\begin{abstract}
MODEL-CALIBRATION DATA SET - All data were collected using USGS protocols and are stored in USGS NWIS databases. The regression model is based on 68 concurrent measurements of turbidity and streamflow and SSC samples collected from November 1998 through June 2005. Samples were collected throughout the range of continuously observed hydrologic and turbidity conditions. Turbidity and streamflow values are time-averaged approved unit values corresponding with the duration of sample collection. A comparison of cross-section mean and corresponding time-series monitor readings is provided. Water-quality data were collected using an YSI 6600 monitor with a 6026 turbidity sensor (FNU). Selected data values used to develop the regression models were removed on the basis of sample evaluation. Five SSC values were removed from the data set because of transcription errors, sampling errors, and a sample compromised during shipping. Three data values were affected by sensor limitations (within 10 percent of the sensor maxima) and, therefore, were removed from the data set. Summary statistics and the complete model-calibration data set are provided.
\end{abstract}

MODEL DEVELOPMENT - Initially, data plots of the response variable $(S S C)$ and possible explanatory variables turbidity and streamflow indicate both are correlated to SSC. Regression analysis was done using S-Plus software, and the final output is provided. Turbidity and streamflow were examined together as explanatory variables for estimating $S S C$, but the p-values for streamflow were larger than 0.025. Different combinations of untransformed and $\log _{10}$-transformed data were evaluated. Log $10^{-}$ transformed turbidity and SSC were selected as the best model on the basis of residual plots, $M S P E$, and p-value for streamflow. Residual plots for evaluating variance, normality, homoscedasticity, and curvature are provided. For $\log _{10}$-transformed models, estimated values were multiplied by a calculated retransformation bias correction factor (Duan, 1983). Ninety-percent prediction intervals are provided for evaluating uncertainty of the estimates.

MODEL SUMMARY - Summary of final regression analysis for suspended-sediment concentration at Little Arkansas River near Sedgwick, Kansas.

$$
\log _{10}(S S C)=0.943 \log _{10}(\text { Turb })+0.130
$$

where

SSC = Suspended-sediment concentration, in milligrams per liter; and

Turb = Turbidity (YSI 6026), in formazin nephelometric units.

\section{Model information:}

Number of measurements $=\mathbf{6 8}$,

root-mean-squared error $(R M S E)=\mathbf{0 . 1 0}$,

model standard percentage error $(M S P E)=+\mathbf{2 5 . 9}$ and $\mathbf{- 2 0 . 6}$ percent

90 -percent prediction intervals $= \pm \mathbf{4 1}$ percent,

adjusted coefficient of determination $\left(R^{2}\right)=\mathbf{0 . 9 8}$,

PRESS $=\mathbf{0 . 6 6 3}$.

Duan's bias correction factor $=\mathbf{1 . 0 3}$.

\section{Coefficients:}

$\begin{array}{lcccl} & \text { Coefficient } & \begin{array}{c}\text { Standard } \\ \text { error }\end{array} & \text { t-statistic } & \text { p-value } \\ \text { Intercept } & 0.130 & 0.041 & 3.02 & 0.0035 \\ \log _{10} \text { (Turb) } & 0.943 & 0.018 & 50.9 & 1.13 \mathrm{E}-54\end{array}$


Correlation matrix of coefficients:

$\begin{array}{lcc} & \text { Intercept } & \log _{10}(\text { Turb }) \\ \text { Intercept } & 1 & \\ \left.\log _{10} \text { (Turb }\right) & -0.9588 & 1\end{array}$

SSC RECORD - The record is computed using a regression model and ADAPS software. Data are computed at 15-minute intervals. The record is complete for the year except as noted. The turbidity monitor was removed for a short period in December-February to avoid ice damage.

Daily values for partial days were updated where data existed during the expected time for the occurrence of the maximum or minimum, if at least 12 hours of values were available for the day, and if values were present adjacent to the extreme for the day.

312 days of record out of 365 days ( 85 percent) will be published.

\section{REMARKS-}

- A new turbidity sensor, YSI model 6136, was installed to collected concurrent turbidity measurements. These measurements will be used to convert YSI model 6136 values to the YSI model 6026 to compute SSC with the new 6136 sensor.

- T.B. Bennett collected field data.

- Cross-section survey results can be retrieved from NWIS, database 02.

- The Excel ${ }^{\circledR}$ "Field Measurement Summary" spreadsheet for this site and water year summarizes the number of site visits, calibration results, and calculations of the magnitude of fouling and calibration drift.

Computed: P.P. Rasmussen, November 1, 2005

Checked: C.J. Lee, November 22, 2005

Reviewed: T.J. Rasmussen, November 26, 2005 
Model-calibration data set for Little Arkansas River near Sedgwick, Kansas, November 1998-June 2005.

\begin{tabular}{|c|c|c|c|c|}
\hline Date & $\begin{array}{l}\text { Turbidity from fixed-location } \\
\text { sensor, in formazin } \\
\text { nephelometric units } \\
\text { (YSI } 6026 \text { turbidity sensor) }\end{array}$ & $\begin{array}{c}\text { Streamflow, } \\
\text { in cubic feet per second }\end{array}$ & $\begin{array}{l}\text { Suspended-sediment } \\
\text { concentration, } \\
\text { in milligrams per liter }\end{array}$ & $\begin{array}{l}\text { Percentage of suspended } \\
\text { sediment finer than } \\
62 \text { micrometers }\end{array}$ \\
\hline November 5, 1998 & 390 & 7,800 & 381 & 92 \\
\hline December 4, 1998 & 100 & 219 & 78 & 99 \\
\hline February 1, 1999 & 977 & 4,460 & 1,180 & 95 \\
\hline February 19, 1999 & 20 & 111 & 19 & 89 \\
\hline April 7, 1999 & 912 & 1,500 & 791 & 98 \\
\hline April 16, 1999 & 924 & 5,410 & 896 & 93 \\
\hline May 24, 1999 & 1,233 & 1,610 & 931 & 99 \\
\hline June 18, 1999 & 457 & 396 & 323 & 100 \\
\hline June 21, 1999 & 452 & 2,080 & 549 & 97 \\
\hline August 3, 1999 & 1,115 & 4,170 & 1,040 & 97 \\
\hline September 28, 1999 & 1,164 & 1,920 & 897 & 99 \\
\hline February 9, 2000 & 19 & 84 & 28 & 86 \\
\hline March 7, 2000 & 448 & 1,120 & 520 & 98 \\
\hline May 19, 2000 & 74 & 87 & 90 & 99 \\
\hline May 31, 2000 & 326 & 175 & 263 & 100 \\
\hline June 28, 2000 & 856 & 1,100 & 835 & 99 \\
\hline July 20, 2000 & 107 & 134 & 129 & 99 \\
\hline August 16, 2000 & 37 & 24 & 35 & 97 \\
\hline September 8, 2000 & 36 & 20 & 36 & 96 \\
\hline September 25, 2000 & 21 & 21 & 14 & 78 \\
\hline October 26, 2000 & 582 & 5,400 & 499 & 78 \\
\hline November 8, 2000 & 112 & 83 & 84 & 97 \\
\hline December 4, 2000 & 6 & 46 & 8 & 81 \\
\hline April 13, 2001 & 947 & 400 & 791 & 100 \\
\hline April 26, 2001 & 36 & 97 & 49 & 85 \\
\hline May 8, 2001 & 217 & 152 & 232 & 100 \\
\hline June 4, 2001 & 808 & 1,040 & 873 & 99 \\
\hline June 6,2001 & 870 & 8,690 & 678 & 92 \\
\hline June 23, 2001 & 525 & 4,260 & 560 & 94 \\
\hline July 11, 2001 & 51 & 67 & 55 & 97 \\
\hline August 2, 2001 & 69 & 25 & 61 & 98 \\
\hline August 28, 2001 & 44 & 28 & 47 & 97 \\
\hline August 28, 2001 & 46 & 28 & 53 & 95 \\
\hline September 20, 2001 & 989 & 4,170 & 877 & 98 \\
\hline October 31, 2001 & 13 & 28 & 18 & 89 \\
\hline
\end{tabular}


Model-calibration data set for Little Arkansas River near Sedgwick, Kansas, November 1998-June 2005.—Continued

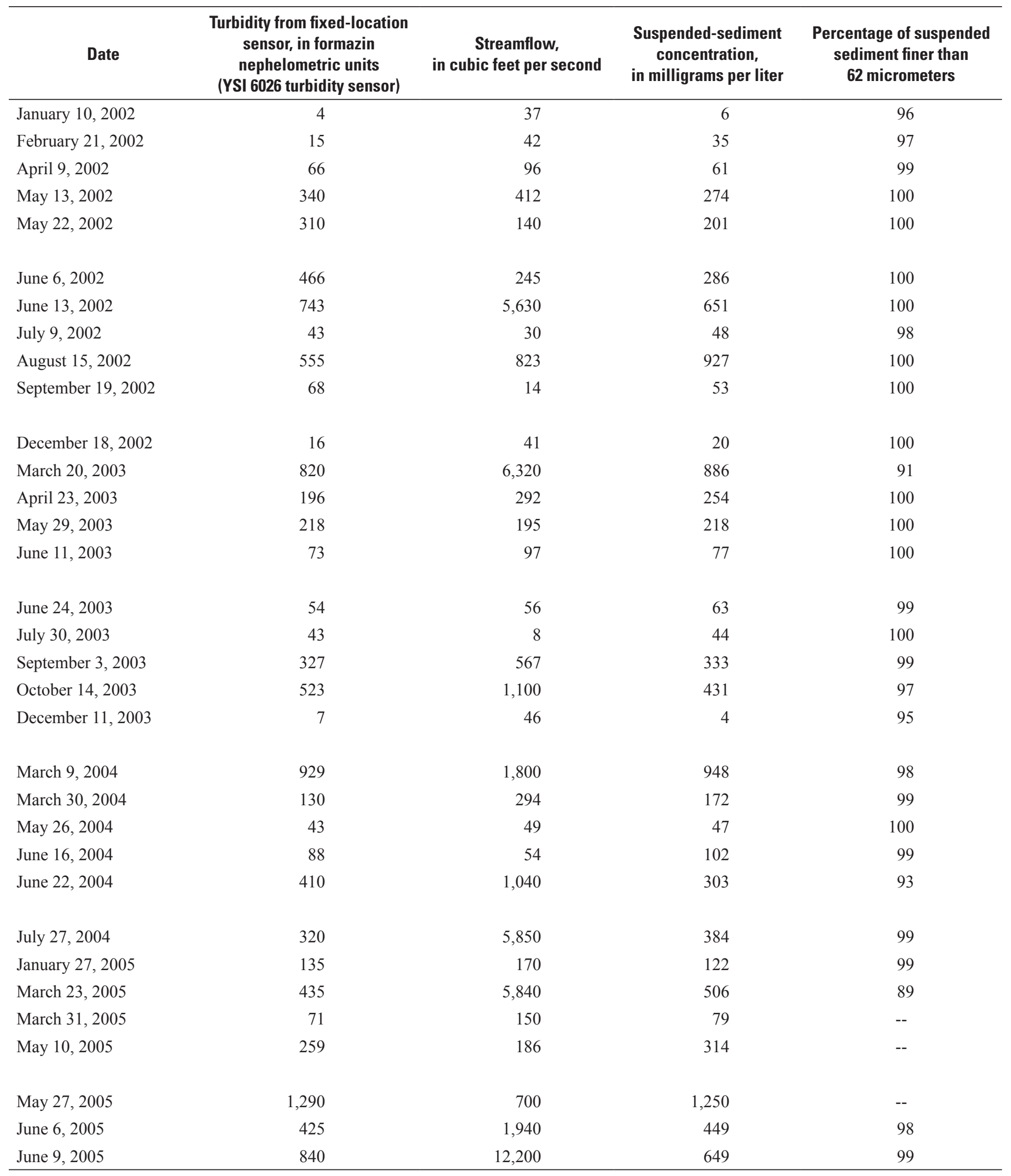


Summary statistics of model-calibration data set for Little Arkansas River near Sedgwick, Kansas, November 1998-June 2005.

[FNU, formazin nephelometric unit; mg/L, milligrams per liter; $\mathrm{ft}^{3} / \mathrm{s}$, cubic feet per second; >, greater than; --, not applicable]

\begin{tabular}{|c|c|c|c|c|c|}
\hline \multicolumn{6}{|c|}{ Statistical summary of data sets } \\
\hline \multirow[b]{2}{*}{ Summary statistic } & \multirow[b]{2}{*}{$\begin{array}{l}\text { Turbidity, } \\
\text { FNU }\end{array}$} & \multicolumn{2}{|c|}{$\begin{array}{c}\text { Calibrated data set } \\
\text { (68 samples) }\end{array}$} & \multicolumn{2}{|c|}{$\begin{array}{c}\text { Time-series data set } \\
\text { (61,368 hourly values) }\end{array}$} \\
\hline & & $\begin{array}{c}\text { Suspended- } \\
\text { sediment } \\
\text { concentration, } \\
\text { mg/L }\end{array}$ & $\begin{array}{c}\text { Streamflow, } \\
\mathrm{ft}^{3} / \mathrm{s}\end{array}$ & $\begin{array}{l}\text { Turbidity, } \\
\text { FNU }\end{array}$ & $\begin{array}{c}\text { Streamflow, } \\
\mathrm{ft}^{3} / \mathrm{s}\end{array}$ \\
\hline Minimum & 4 & 4 & 8 & 65 & 55 \\
\hline Maximum & 1,300 & 1,200 & 12,000 & $>2,000$ & 16,000 \\
\hline Mean & 370 & 350 & 1,500 & 140 & 380 \\
\hline Median & 250 & 240 & 210 & 41 & 60 \\
\hline Standard deviation & 370 & 350 & 2,500 & 260 & 1,200 \\
\hline Missing turbidity values & -- & -- & -- & 1,264 & 643 \\
\hline Turbidity values greater than maximum sensor limit & -- & -- & -- & 254 & -- \\
\hline
\end{tabular}




\section{S-Plus Output of Regression Model Development of Turbidity and SSC for Little Arkansas River near} Sedgwick, Kansas

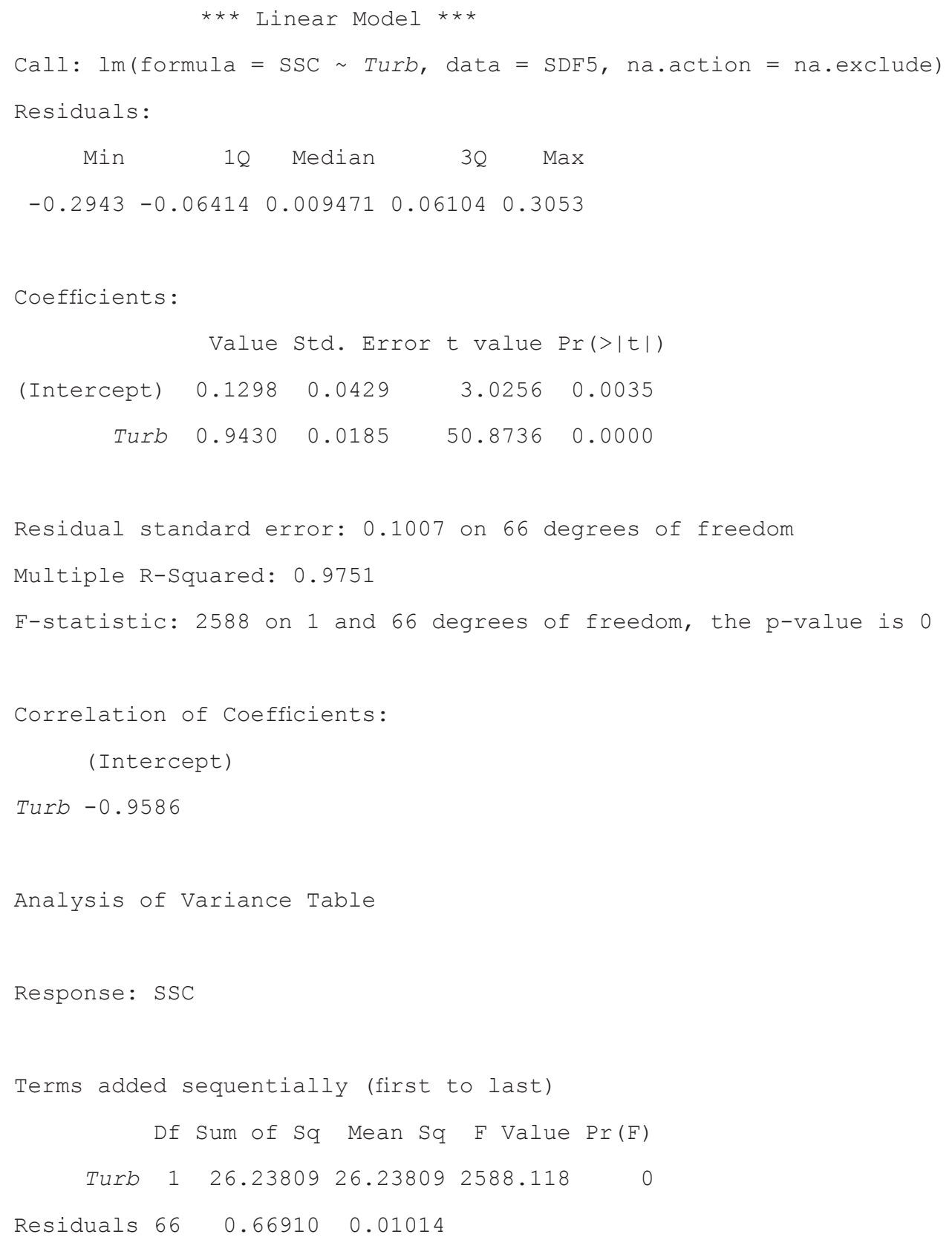




\section{Example 2. Turbidity Computed Suspended-Sediment Concentrations from Oregon}

From Bragg, H.M., Sobieszczyk, Steven, Uhrich, M.A., and Piatt, D.R., 2007, Suspended-sediment loads and yields in the North Santiam River Basin, Oregon, water years 1999-2004: U.S. Geological Survey Scientific Investigations Report 20075187, 26 p., available on Web, accessed March 2008, at http://pubs.usgs.gov/sir/2007/5187

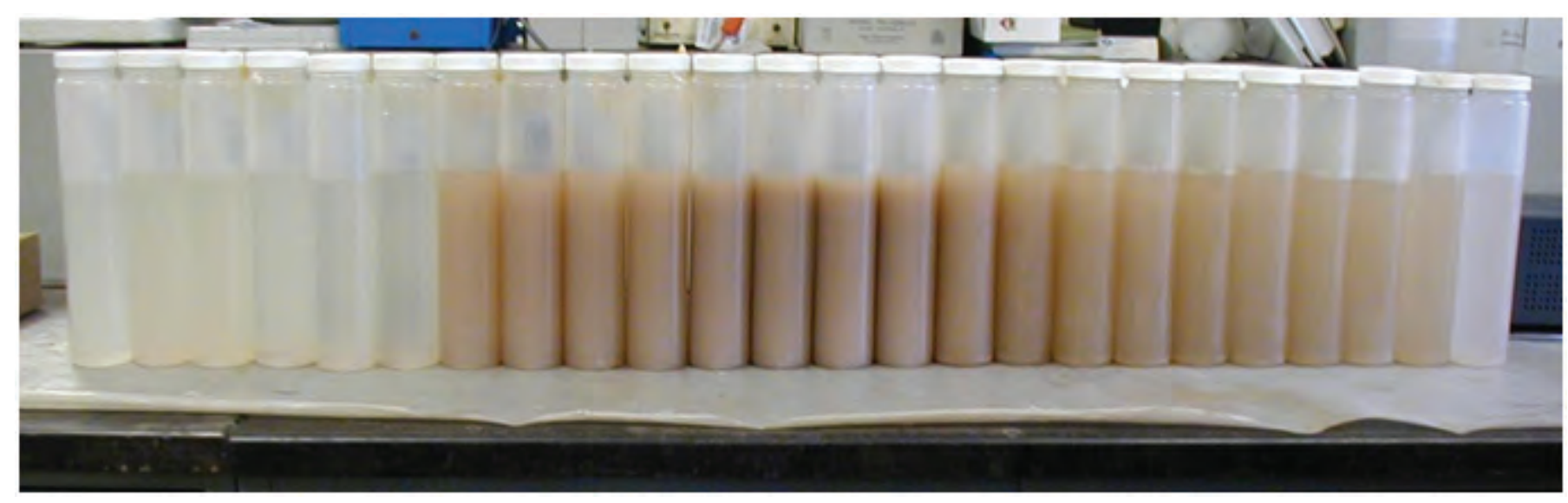

Samples collected every 15 minutes during a single period of runoff. (Photograph by Heather Bragg, U.S. Geological Survey, October 20-22, 2003.) 
Model-calibration data set for North Santiam River below Boulder Creek, Oregon, October 1998-August 2004.

$\left[Q\right.$, streamflow; $\mathrm{ft}^{3} / \mathrm{s}$, cubic feet per second; FNU, formazin nephelometric units; SSC, suspended-sediment concentration; $\mathrm{mg} / \mathrm{L}$, milligrams per liter]

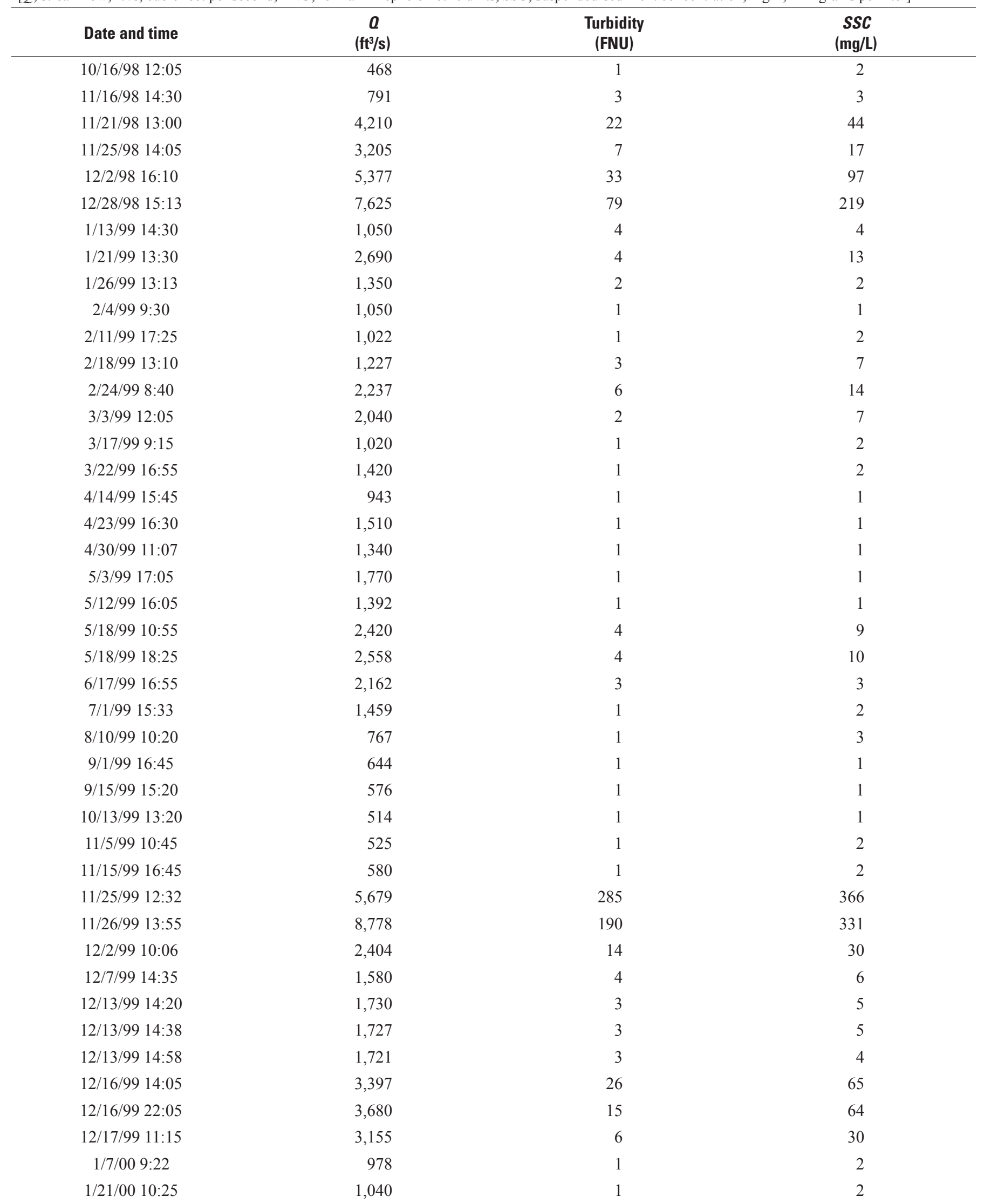


Model-calibration data set for North Santiam River below Boulder Creek, Oregon, October 1998-August 2004.-Continued

$\left[Q\right.$, streamflow; $\mathrm{ft}^{3} / \mathrm{s}$, cubic feet per second; FNU, formazin nephelometric units; SSC, suspended-sediment concentration; $\mathrm{mg} / \mathrm{L}$, milligrams per liter $]$

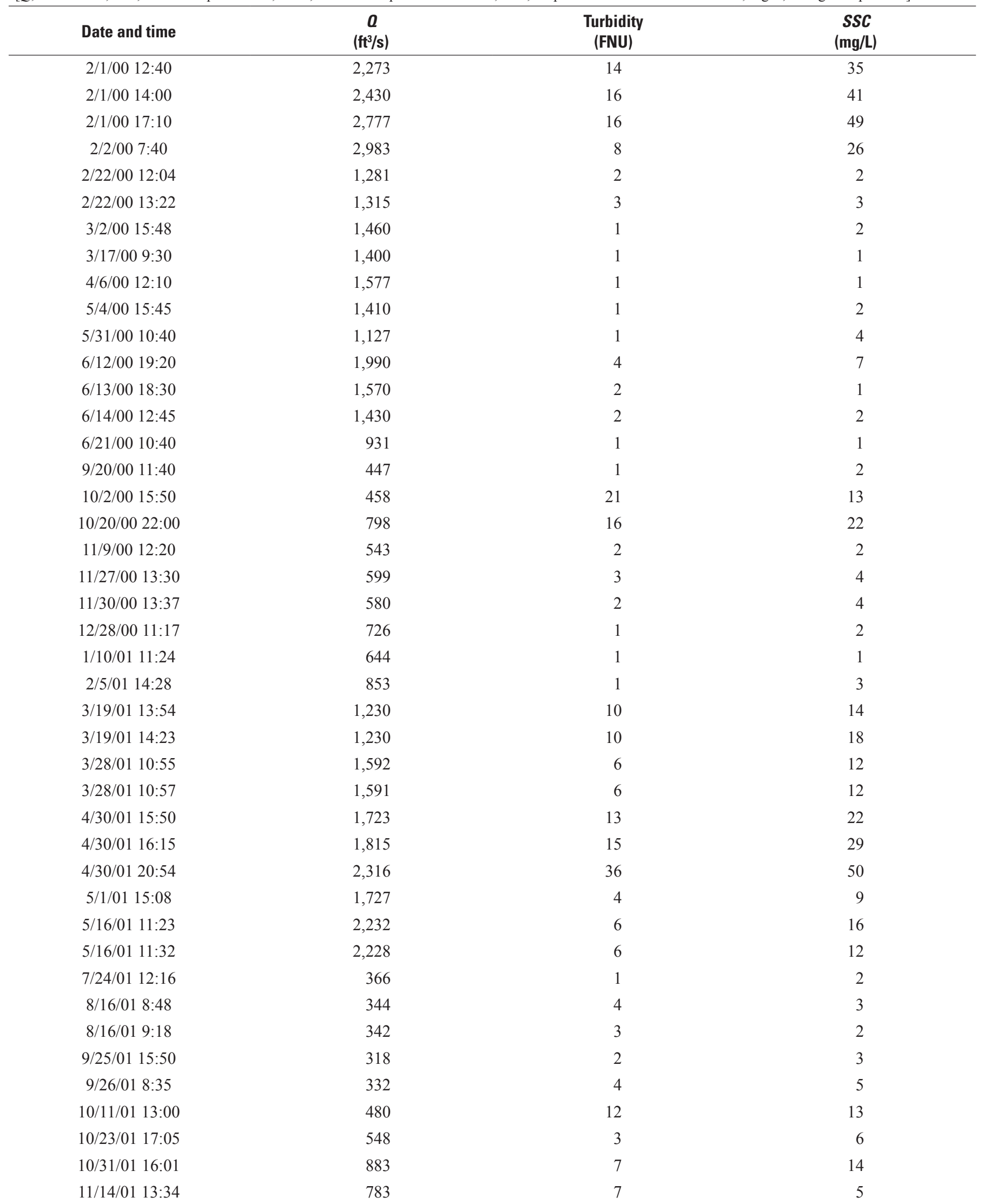


42 Computing Time-Series Suspended-Sediment Concentrations and Loads from Turbidity-Sensor and Streamflow Data

Model-calibration data set for North Santiam River below Boulder Creek, Oregon, October 1998-August 2004.-Continued

$\left[Q\right.$, streamflow; $\mathrm{ft}^{3} / \mathrm{s}$, cubic feet per second; FNU, formazin nephelometric units; SSC, suspended-sediment concentration; mg/L, milligrams per liter]

\begin{tabular}{|c|c|c|c|}
\hline Date and time & $\underset{\left(f t^{3} / s\right)}{0}$ & $\begin{array}{l}\text { Turbidity } \\
\text { (FNU) }\end{array}$ & $\begin{array}{c}S S C \\
(\mathrm{mg} / \mathrm{L})\end{array}$ \\
\hline $11 / 22 / 0115: 30$ & 3,280 & 64 & 147 \\
\hline $11 / 23 / 01 \quad 12: 56$ & 2,111 & 7 & 14 \\
\hline $11 / 23 / 01 \quad 13: 16$ & 2,089 & 7 & 15 \\
\hline 11/29/01 10:10 & 2,033 & 5 & 15 \\
\hline 12/7/01 9:00 & 1,890 & 3 & 5 \\
\hline 12/14/01 11:40 & 3,427 & 13 & 28 \\
\hline $12 / 16 / 01 \quad 15: 26$ & 3,450 & 11 & 34 \\
\hline $12 / 16 / 01 \quad 15: 45$ & 3,440 & 11 & 38 \\
\hline 1/8/02 11:17 & 5,209 & 43 & 134 \\
\hline 2/21/02 14:02 & 907 & 1 & 2 \\
\hline $3 / 12 / 0211: 33$ & 2,969 & 8 & 23 \\
\hline 4/14/02 13:36 & 7,350 & 87 & 225 \\
\hline $7 / 18 / 027: 27$ & 650 & 11 & 9 \\
\hline $12 / 11 / 0216: 00$ & 644 & 7 & 7 \\
\hline $12 / 16 / 02 \quad 10: 48$ & 1,440 & 8 & 16 \\
\hline $12 / 16 / 0211: 22$ & 1,440 & 7 & 13 \\
\hline $12 / 27 / 02 \quad 16: 24$ & 1,428 & 8 & 15 \\
\hline 1/3/03 14:40 & 2,670 & 8 & 37 \\
\hline 1/30/03 15:24 & 6,216 & 63 & 213 \\
\hline 3/22/03 12:01 & 4,903 & 34 & 157 \\
\hline 8/18/03 15:10 & 395 & 5 & 3 \\
\hline $8 / 21 / 037: 40$ & 385 & 4 & 3 \\
\hline 9/12/03 13:30 & 395 & 17 & 11 \\
\hline 9/12/03 14:45 & 392 & 14 & 9 \\
\hline $10 / 21 / 03 \quad 12: 31$ & 395 & 569 & 415 \\
\hline $10 / 21 / 03 \quad 15: 16$ & 390 & 216 & 173 \\
\hline $10 / 23 / 0313: 55$ & 385 & 19 & 18 \\
\hline 10/29/03 11:31 & 375 & 39 & 26 \\
\hline 11/19/03 13:45 & 799 & 4 & 9 \\
\hline $12 / 13 / 03 \quad 17: 00$ & 6,080 & 118 & 418 \\
\hline 1/29/04 9:04 & 4,031 & 16 & 70 \\
\hline 6/25/04 16:02 & 719 & 10 & 11 \\
\hline $7 / 21 / 049: 43$ & 502 & 3 & 4 \\
\hline $8 / 25 / 0411: 24$ & 655 & 14 & 18 \\
\hline 8/25/04 15:32 & 791 & 23 & 29 \\
\hline
\end{tabular}



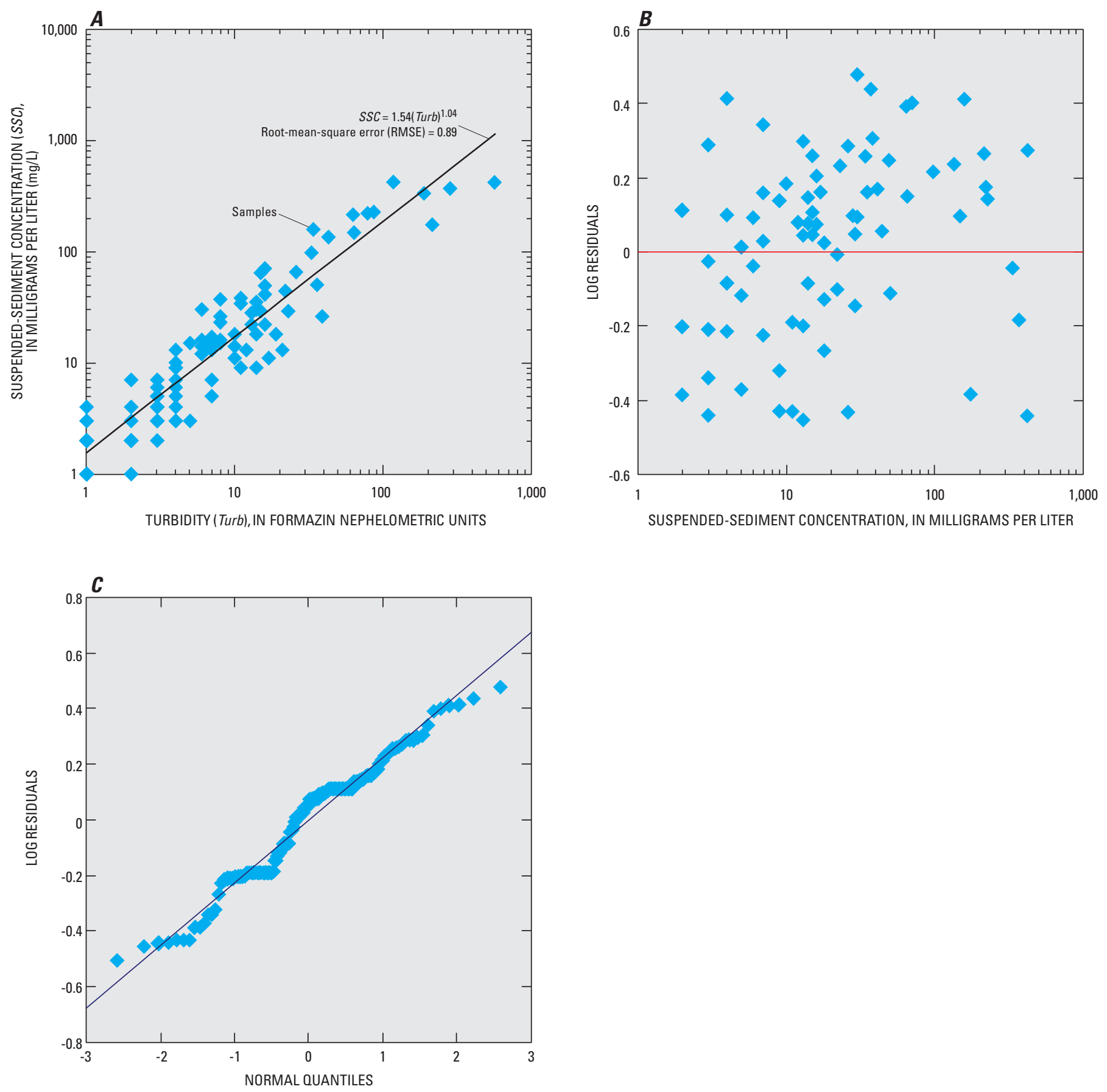

Results for simple linear regression analysis for $A$, turbidity and suspended-sediment concentration data, and comparison of $B$, computed suspended-sediment concentrations and regression residuals, and $C$, probability plot of residuals for U.S. Geological Survey streamgage on North Santiam River below Boulder Creek, Oregon, 1998-2004. 


\section{Example 3. Turbidity Computed Suspended-Sediment Concentrations from Florida}

From Lietz, A.C., and Debiak, E.A., 2005, Development of rating curve estimators for suspended-sediment concentration and transport in the C-51 canal based on surrogate technology, Palm Beach County, Florida, 2004-05: U.S. Geological Survey Open-File Report 2005-1394, 19 p., available on Web, accessed March 2008, at http://pubs.usgs.gov/of/2005/1394

Model-calibration data set for C-51 Canal, Palm Beach County, Florida, November 2003-December 2004.

[SSC, suspended-sediment concentration, in milligrams per liter; Turb, turbidity, in formazin nephelometric units; $Q$, streamflow, in cubic feet per second; mm, millimeters; --, not determined]

\begin{tabular}{|c|c|c|c|c|}
\hline $\begin{array}{c}\text { Date } \\
\text { (month/ } \\
\text { day/year) }\end{array}$ & SSC & Turb & 0 & $\begin{array}{c}\text { Percentage } \\
\text { finer than } \\
0.063 \mathrm{~mm}\end{array}$ \\
\hline $11 / 13 / 03$ & 6 & 4.2 & 408 & 89 \\
\hline $11 / 17 / 03$ & 6 & 6.5 & 871 & 98 \\
\hline $02 / 10 / 04$ & 16 & 13.4 & 857 & 97 \\
\hline $02 / 26 / 04$ & 15 & 15.8 & 955 & 97 \\
\hline $03 / 15 / 04$ & 9 & 10.4 & 246 & 94 \\
\hline $04 / 12 / 04$ & 8 & 4.6 & 1,010 & 36 \\
\hline $07 / 27 / 04$ & 5 & 2.9 & 735 & 53 \\
\hline $08 / 02 / 04$ & 7 & 4.6 & 226 & 77 \\
\hline 08/04/04 & 6 & 6.2 & 678 & 89 \\
\hline 08/06/04 & 6 & 4.8 & 0 & 82 \\
\hline 08/13/04 & 7 & 6.5 & 718 & 94 \\
\hline 08/14/04 & 8 & 6.2 & 696 & 84 \\
\hline $08 / 27 / 04$ & 5 & 4.1 & 481 & 83 \\
\hline 09/07/04 & 25 & 18.1 & 2,690 & 96 \\
\hline 09/08/04 & 16 & 7.8 & 2,180 & 97 \\
\hline $09 / 22 / 04$ & 17 & 24.2 & 1,920 & 98 \\
\hline 09/27/04 & 30 & 23.1 & 4,060 & 94 \\
\hline $10 / 13 / 04$ & 20 & 14.0 & 1,499 & 97 \\
\hline $10 / 27 / 04$ & -- & -- & 869 & 95 \\
\hline $11 / 09 / 04$ & 14 & 24.0 & 267 & 93 \\
\hline $12 / 15 / 04$ & 54 & 78.0 & 584 & 95 \\
\hline
\end{tabular}



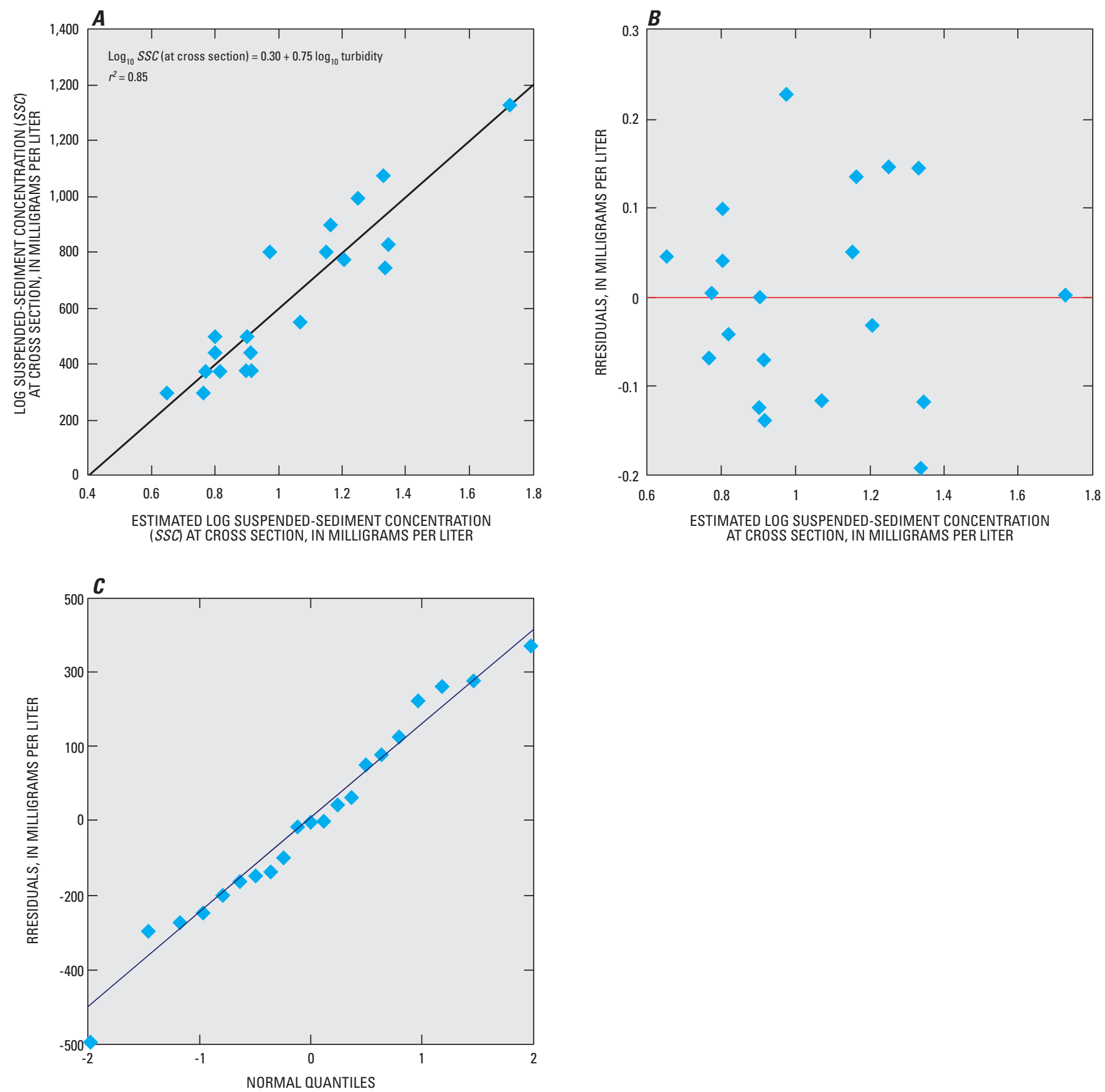

Results for simple linear regression analysis for $A$, turbidity and suspended-sediment concentration data, and comparison of $B$, computed suspended-sediment concentrations and regression residuals, and $C$, probability plot of residuals for U.S. Geological Survey streamgage on C-51 canal, Palm Beach County, Florida, 2003-4. 


\section{Example 4. Turbidity (Optical Backscatter) Computed Suspended-Sediment Concentrations Using Nonparametric Regression, California}

From Buchanan, P.A., and Ganju, N.K., 2004, Summary of suspended-sediment concentration data, San Francisco Bay, California, water year 2002: U.S. Geological Survey Open-File Report 2004-1219, 45 p., available on Web, accessed March 2008, at http://pubs.usgs.gov/of/2004/1219

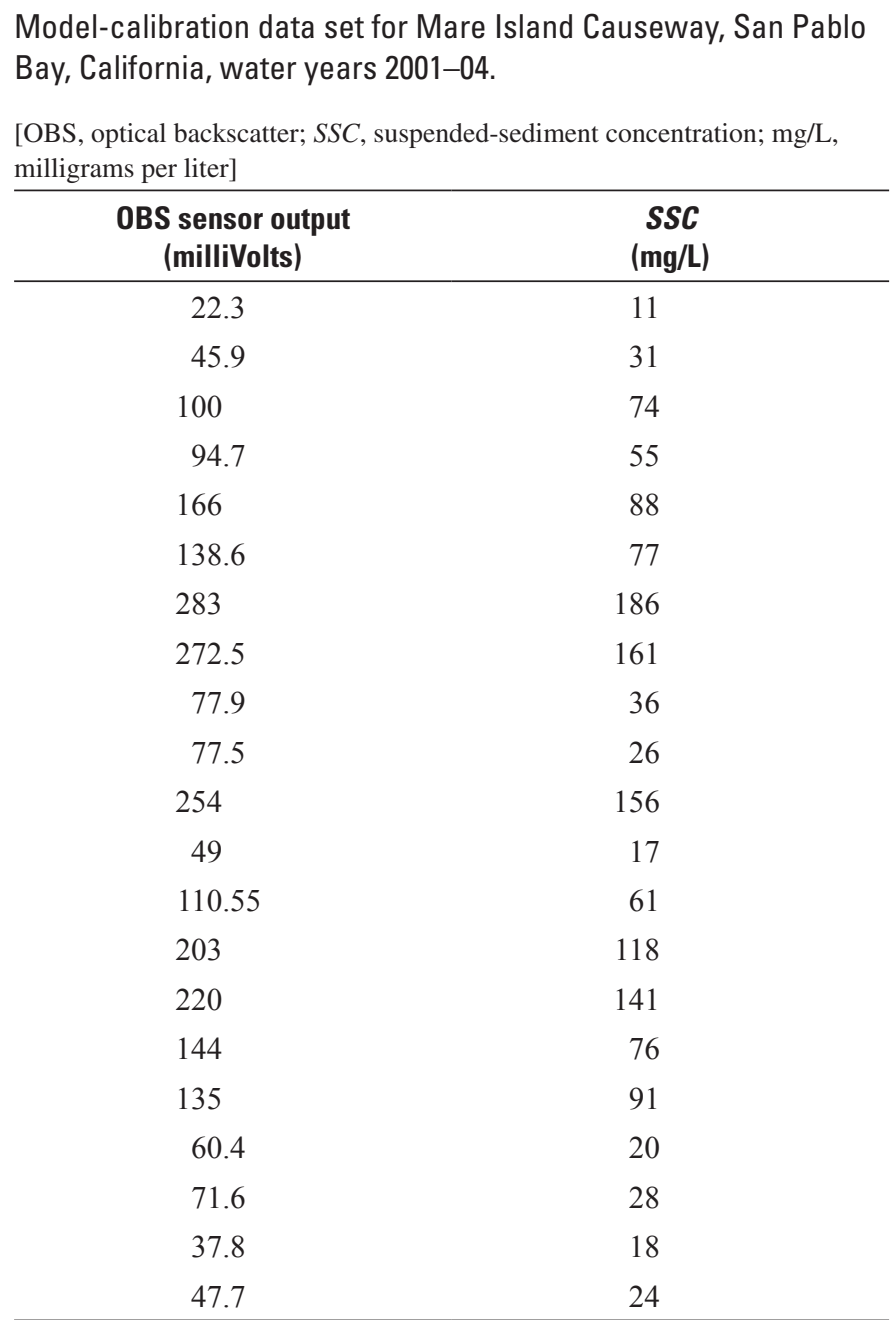




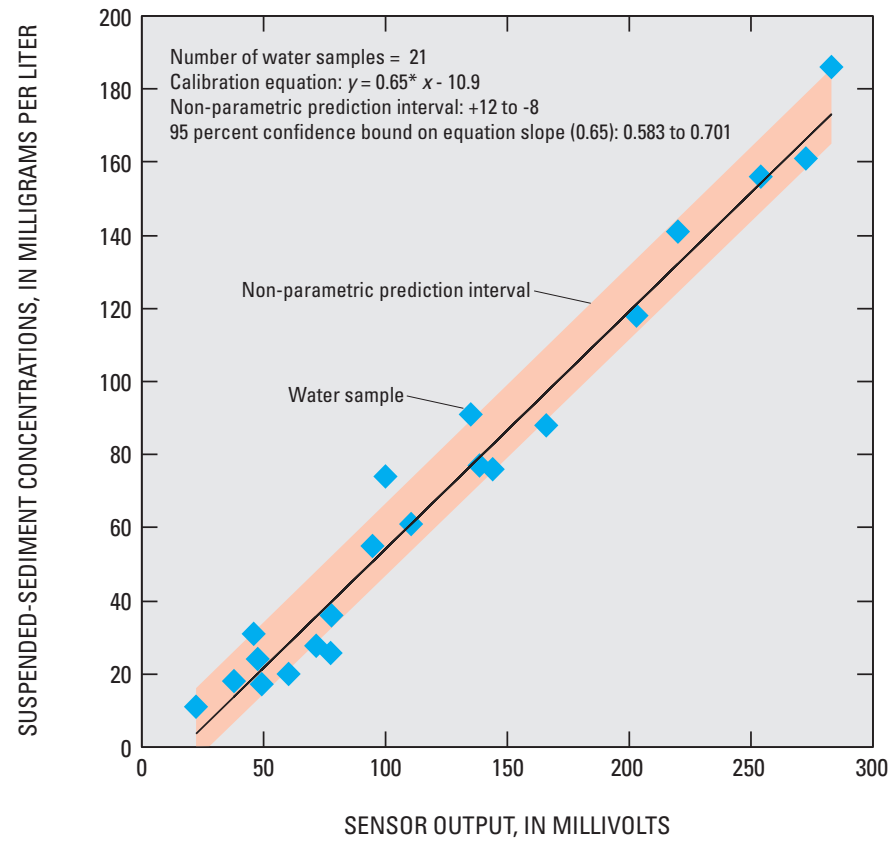

Calibration of mid-depth optical backscatter sensor at Mare Island Causeway, San Pablo Bay, California, water year 2004 (from Buchanan and Ganju, 2004). 


\section{Appendix 2. Computation, Storage, and Real-Time Display of Time-Series Suspended-Sediment Concentration and Load in National Water Information System}

In some cases, ADAPS, a subsystem of NWIS, can compute SSC unit values (UVs) and SSL daily values (DVs). SSC UVs can only be computed in NWIS if turbidity is the sole explanatory variable in the regression model. Currently (2009), NWIS cannot compute $S S C$ values if:

1. The model includes computed UVs, such as streamflow, for an explanatory variable, or

2. The model is a MLR model.

For SSC models that NWIS cannot compute, the hydrographer should refer to the Graphical Constituent Loading Analysis System (GCLAS; Koltun and others, 2006) or a spreadsheet application. The time series of computed SSC unit values then can be loaded to ADAPS using Device Conversion and Delivery System (DECODES) (U.S. Geological Survey, 2003).

SSL DVs are computed using mean daily SSC and streamflow. The resulting SSL DV is correct only if the SSC and streamflow are correlated in time. Typically, this is not the case and results in erroneous SSL DVs. Hydrographers should instead use GCLAS or a spreadsheet application to compute SSL UVs and DVs. The time series of computed SSL unit values then can be loaded to ADAPS using DECODES (U.S. Geological Survey, 2003).

The following presents the general methods for computation, storage, and real-time display of SSC unit values and SSL daily values using NWIS. For complete instructions, refer to U.S. Geological Survey (2003), http://pubs.usgs.gov/of/2003 ofr03123 NOTE: The user must have a user class of "adba" or "syst" to have access to perform several of the following steps (U.S. Geological Survey, 2003).

In ADAPS, the site must have a data descriptor (DD) for computed:

- SSC unit values (NWIS parameter code 99409—suspended-sediment concentration, water, unfiltered, estimated by regression equation, milligrams per liter) and

- SSL unit values (NWIS parameter code 80295 - sediment suspended sediment load, water, unfiltered, estimated by regression equation, pounds per second, 80296-sediment suspended sediment load, water, unfiltered, estimated by regression equation, tons per second, 80297-suspended sediment load, water, unfiltered, computed, the product of regression-computed suspended sediment concentration and streamflow, tons per day, or 80298-suspended sediment load, water, unfiltered, regression computed, turbidity and streamflow as regressors, tons per day).

The DD setup for SSC and SSL should include:

1. Adding a DD optional description (30 characters maximum).

SSC-Add the SLR model (example, "SSC = 1.39Turb^0.943")

$S S L$ — example, "by regression using turbidity DD\#\#," where DD\#\# is the turbidity data descriptor number.

2. The processor for the SSC DD needs to be identified as a "standard rating computation" and have the turbidity DD identified as the input DD.

3. The rating values of measured turbidity and estimated SSC should be calculated outside of ADAPS using the SLR model and the BCF and entered as a "dependent, parameter" rating. The proper "rating expansion type" for Little Arkansas River near Sedgwick, Kansas example is "equation."

- The rating "Remarks" (99 characters maximum) should include the SLR model, the BCF, and the turbidity sensor's manufacturer and model number and (or) the parameter and method codes. (example, $S S C=1.39 \mathrm{Turb}^{\wedge} 0.943$, turb $=$ YSI 6026 = DD\#\#, parameter 63680, method TS086).

- The SSC values for Little Arkansas River near Sedgwick, Kansas, are computed using equation 7, where the BCF is incorporated into the model.

- When SSC model coefficients change due to addition of samples, the rating, rating remarks, and start and end dates need to be updated. 


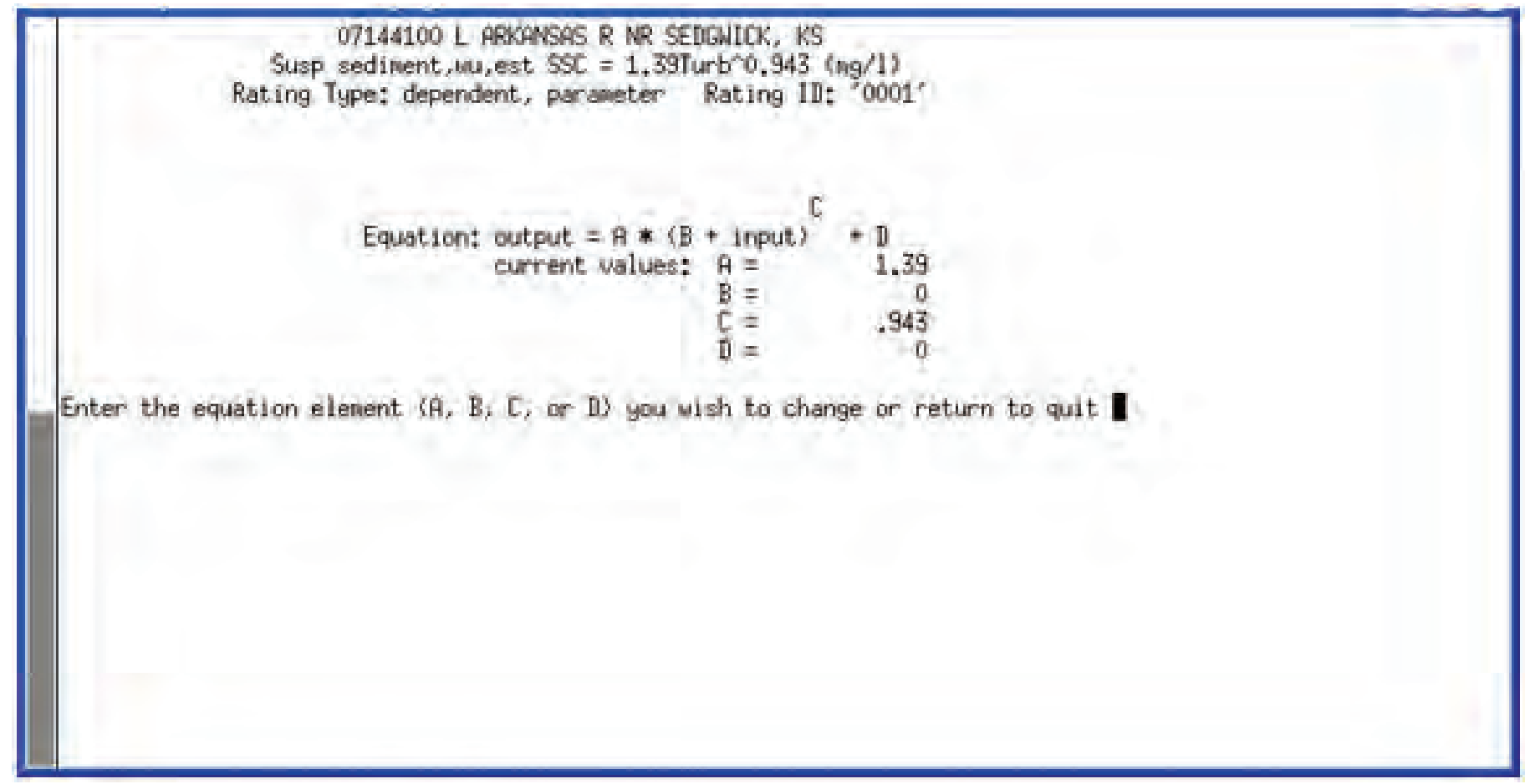

4. Primary computation must be performed on the SSC DD to compute the SSC UVs.

- In ADAPS, select menu options:

"PR-Primary Data Processing,"

"7-Primary Computations,"

select the desired site number, DD, and dates,

$<$ Enter $>$

select the desired options, and

$<$ Enter $>$.

- Enter Hydra to compare SSC UVs with turbidity UVs;

select "PR - Primary Data Processing,"

select "2-Edit Time-Series Data using Hydra,"

select "3. COMPUTED UNIT VALUES,"

select the desired site number, DD, and dates, and

add a reference curve for the turbidity DD.

- View the plot of the two curves and verify that the data look correct. For instance, for the Little Arkansas River near Sedgwick, Kansas, the $S S C$ and turbidity are nearly identical at values less than 400 . For $S S C$ values larger than 400, the difference increases as SSC increases so that turbidity is larger than SSC. 
5. Currently (2009), ADAPS computes mean daily SSL from mean daily SSC and streamflow and the appropriate conversion factor. The resulting SSL DV is only correct if SSC and streamflow are highly correlated $(r>0.95)$. In most cases, they are not highly correlated, and therefore, ADAPS should not be used to compute SSL. The hydrographer should use either GCLAS or a spreadsheet application for the computation of SSL UVs or DVs. If the hydrographer can verify that the SSC and streamflow for their site is highly correlated $(r>0.95)$, then the following instructions can be used to compute SSL DVs in ADAPS.

Primary computations must be performed on the SSL DD to compute SSL DVs.

- Compute SSL DVs using DV_MANIP in ADAPS. From the ADAPS prompt: type DV_MANIP (or "PR 9"), select "A" to write the DVs to ADAPS,

select the desired site number, dates, and the SSL DD,

$<$ Enter $>$,

select option (8) compute load from streamflow and concentration,

select "A,"

select the desired site number, dates, and the streamflow DD,

$<$ Enter $>$,

select "A,"

select the desired site number, dates, and the SSC DD,

select "e" (edited or estimated) to set the DV remark code, and select "s" to store the data in ADAPS.

6. Plot to SSL DVs, SSC UVs, and streamflow UVs in either Hydra or Tkg2 for comparison.

7. NWISWeb can be configured to display up to 60 days of SSC unit values, all available daily values, daily, monthly, and annual statistics for turbidity, streamflow, SSC, and SSL and SSC values from discrete sample collection. 


\section{Appendix 3. Comparison of Computed Suspended-Sediment Concentrations with Water-Quality Criteria}

Currently (2009), there are no State criteria for SSC. Five States (Hawaii, Nevada, New Jersey, South Dakota, and Utah) have numeric criteria for total suspended solids (TSS), which range from a minimum concentration of 35 milligrams per liter $(\mathrm{mg} / \mathrm{L})$ in Utah to a maximum of $158 \mathrm{mg} / \mathrm{L}$ in South Dakota (U.S. Environmental Protection Agency, 2001). The differences between values of SSC and TSS as metrics for the suspended solid-phase content of surface waters are discussed in Gray and others (2000). SSC remains one of the most cited water-quality impairments in the United States even with the lack of State criteria. The SSC values computed using SLR methods have a quantifiable uncertainty that allows for several methods of comparison with criteria. In the following examples, $100 \mathrm{mg} / \mathrm{L}$ is an assumed $S S C$ water-quality criterion for comparison.

Continuous SSC can be used, for example, to construct cumulative frequency distribution (duration) curves to determine percentage of time that computed concentrations exceed water-quality criteria. Computed concentration duration curves can be used to evaluate current water-quality conditions and to estimate the duration and magnitude of potential water-quality degradation. Without SSC water-quality criteria, water-resource managers can use duration curves to assess how frequent a potential water-quality criterion may be exceeded. When OLS regression is used to generate estimates for which probability statements are made, such as with duration curves and probability of exceeding criteria, values at the upper end likely are underestimated, and values at the lower end may be overestimated (Helsel and Hirsch, 2002).

In the example below, 28 percent of the hourly computed $S S C$ values exceeded $100 \mathrm{mg} / \mathrm{L}$ for the period October 1999 through September 2005. The 90-percent prediction interval indicates that $100 \mathrm{mg} / \mathrm{L}$ could be exceeded 22 to 36 percent of the time. Simple linear regression (SLR) was used to compute the values plotted in figure 20 after SLR was determined to be the most appropriate regression technique. Like all regression techniques, the true relation of the response and explanatory variables is unknown, and the regression model is only an estimate of this relation. Other regression techniques might yield different models and, therefore, different duration curves. The differences between regression techniques typically are within the 90-percent prediction interval of the SLR regression.

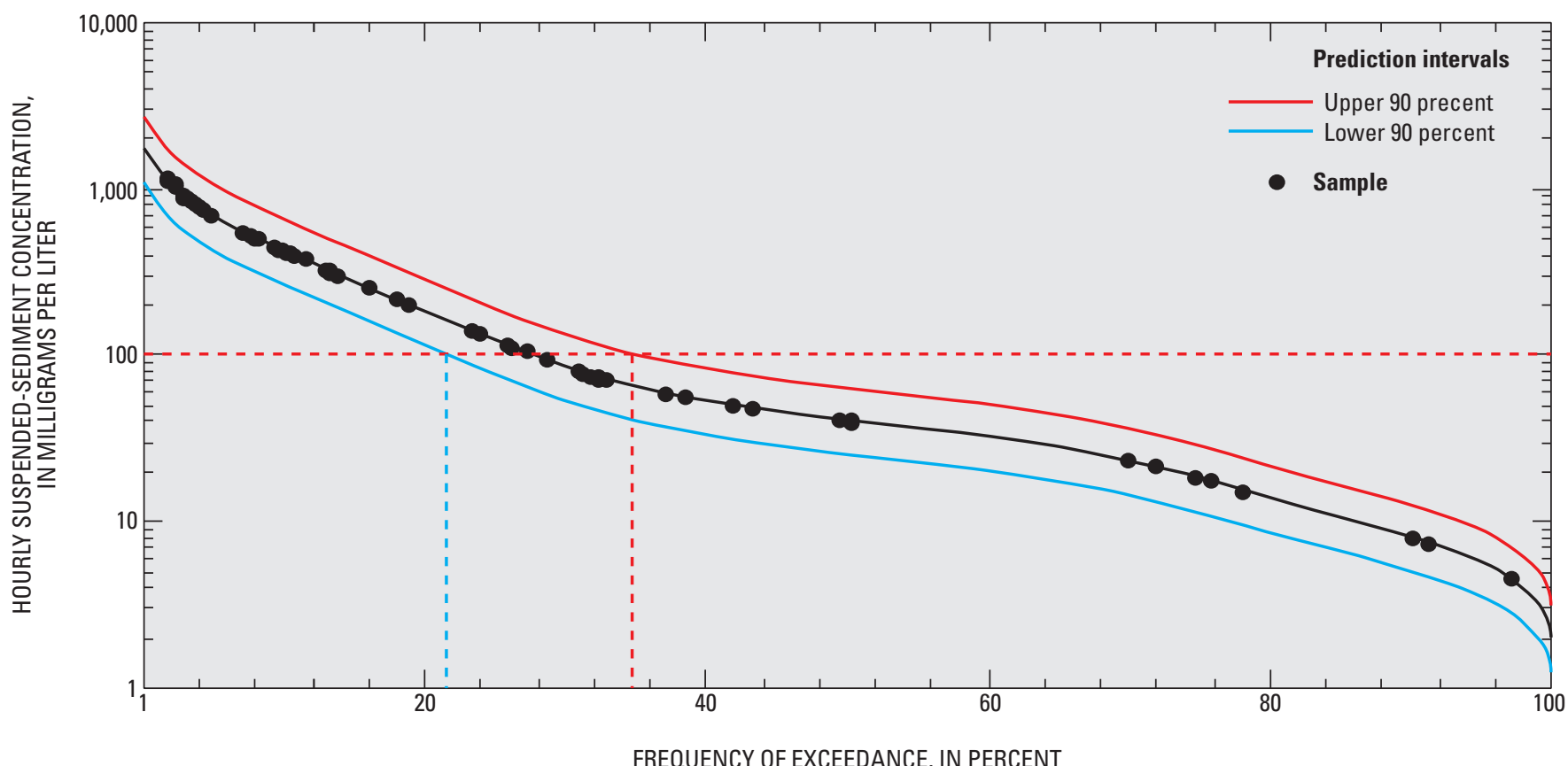

Duration curve and 90-percent prediction intervals for computed hourly suspended-sediment concentrations in Little Arkansas River near Sedgwick, Kansas, October 1999-September 2005. 
Although prediction intervals are approximate indicators of uncertainty, a range of values is not very useful for comparing the water quality of a stream to water-quality criteria. Probability of exceedance provides water managers with a single hourly value for decisionmaking. Probabilities of exceeding designated water-quality criteria or other values of interest for a $\log _{10}$ transformed model can be determined as follows:

$$
\operatorname{Pr}(S S C \leq \text { Criterion })=1-D\left[\frac{\log _{10}(S S C)-\log _{10}(\text { Criterion })}{R M S E}\right]
$$

where

$\operatorname{Pr} \quad$ is the probability that the criterion has been exceeded $(0<\operatorname{Pr}<1)$,

$D \quad$ is the cumulative distribution function for the standard normal curve - values for it are obtained from tables in statistics textbooks or equations that approximate the exact values,

$S C \quad$ is the BCF-corrected, regression-computed SSC value;

Criterion assumed $100 \mathrm{mg} / \mathrm{L}$ [if $R M S E$ is in $\log _{10}$ space, then criterion is $\log _{10}(100)$ ]; and

$R M S E$ is root-mean-squared error, or standard error of the regression, or standard deviation of the residuals.

The probability of hourly SSC also can be displayed as probability curves. Each curve represents an SSC and is plotted using frequency of exceedance (x axis) and the probability that the actual SSC is equal to the given threshold (y axis). The figures can be used to estimate the frequency of exceedance for 5 values of SSC. For instance, 20 percent of all hourly values of SSC for Little Arkansas River at Sedgwick have a 99-percent chance of exceeding $100 \mathrm{mg} / \mathrm{L}$. Two percent of all hourly $S S C$ values have a 50-percent chance of exceeding 1,000 mg/L for Little Arkansas River at Sedgwick.

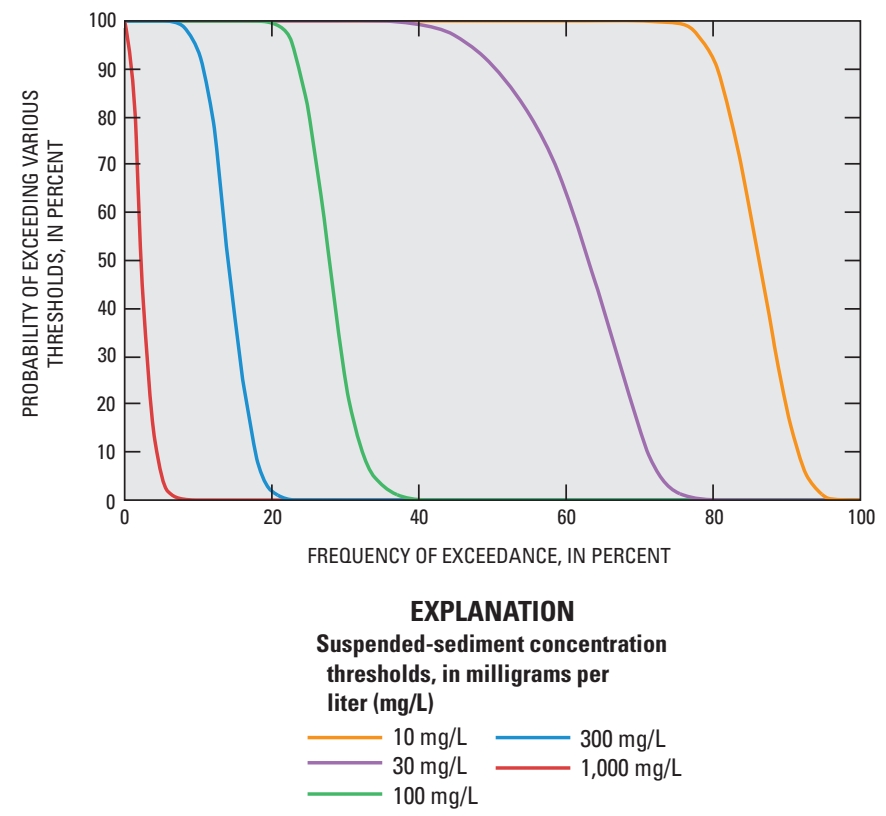

Cumulative frequency curves showing probability of exceedance of suspended-sediment concentration thresholds of 10,30, 100, 300, and 1,000 milligrams per liter, Little Arkansas River near Sedgwick, Kansas, 1999-2005. 
Publishing support provided by: Rolla Publishing Service Center

For more information concerning this publication, contact: Director, USGS Kansas Water Science Center 4821 Quail Crest Place

Lawrence, KS 66049

(785) 842-9909

Or visit the Kansas Water Science Center Web site at: http://ks.water.usgs.gov 


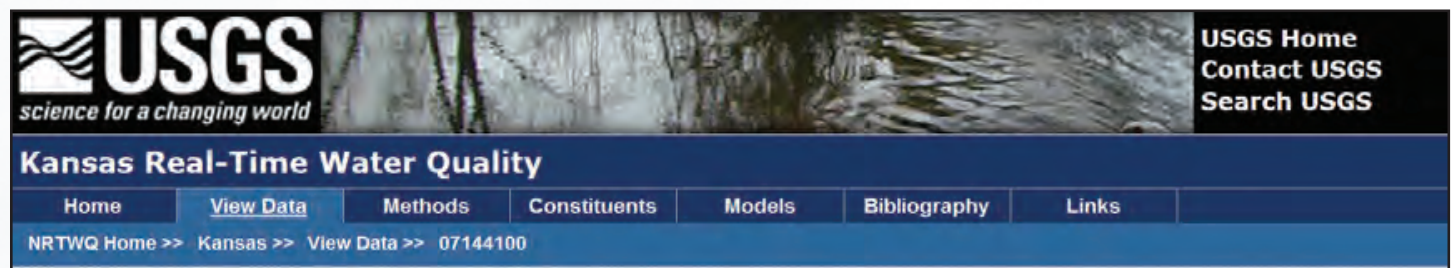

\section{Plot Data Table Statistics Duration Curve Site Info Model Info}

usGS station: 07144100 Little Arkansas River near Sedgwick, KS

Constituent:

Computed suspended sediment

D. a Go to NWISWeb

Time period:

Year $2007 \sim 2$ 2nd Quarter (Apr-Jun)

\section{- concentration $\nabla$ hourly $\nabla \mid\langle$ Go $\rangle$}

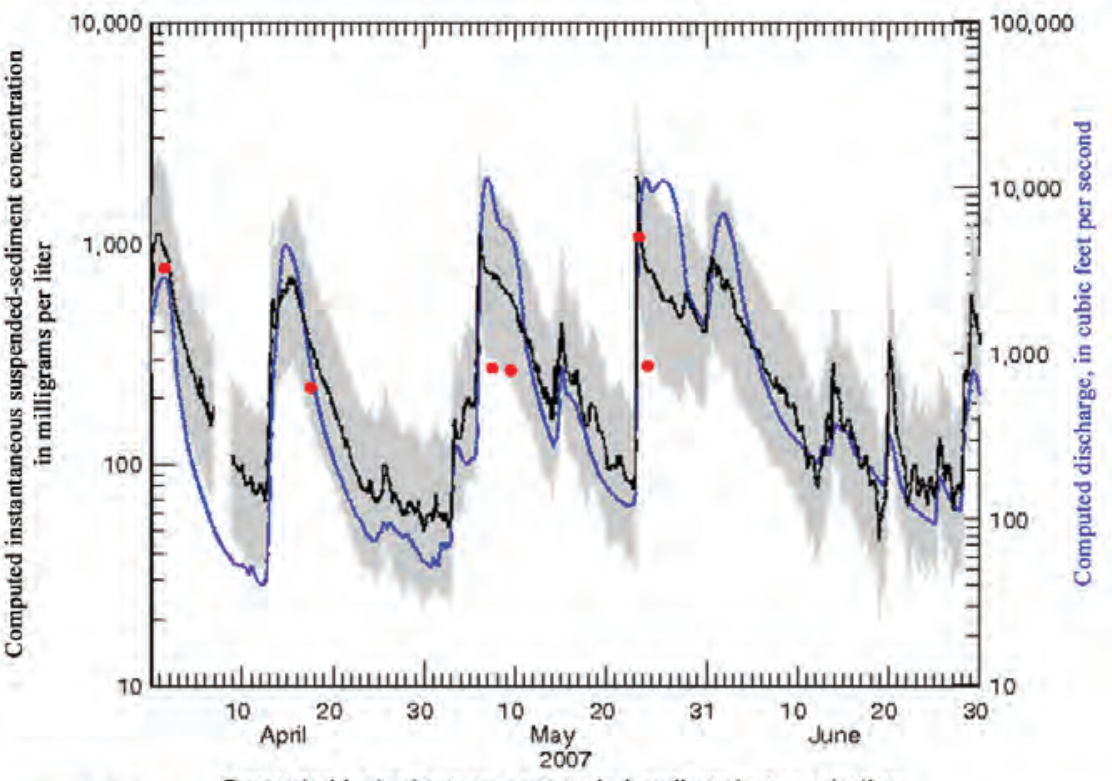

叉USGS

Computed instantaneous suspended-sediment concentration in Little Arkansas River near Sedgwick, KS

\section{EXPLANATION}

Generated 10-6-10 18:44

— Discharge

Measured or computed water-quality constituent

90-percent prediction interval for computed value

- Value obtained from discrete sampling and analysis

\section{http://nrtwq.usgs.gov}

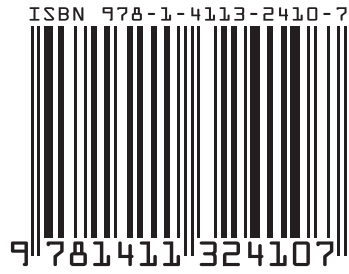

